NBER WORKING PAPER SERIES

\title{
TECHNOLOGY TRANSFER AND EARLY INDUSTRIAL DEVELOPMENT: EVIDENCE FROM THE SINO-SOVIET ALLIANCE
}

\author{
Michela Giorcelli \\ Bo Li \\ Working Paper 29455 \\ http://www.nber.org/papers/w29455 \\ NATIONAL BUREAU OF ECONOMIC RESEARCH \\ 1050 Massachusetts Avenue \\ Cambridge, MA 02138
}

November 2021, Revised January 2022

We thank David Atkin, Bruno Caprettini, Dora Costa, Michele Di Maio (discussant), Alvaro Garcia, Rick Hornbeck (discussant), Jiandong Ju, Naomi Lamoreaux, Nicholas Li, Ernest Liu, Kalina Manova (discussant), Nathan Nunn, Luigi Pascali, Nancy Qian, Xuan Tian, John Van Reneen, Eric Verhoogen, Guo Xu, Ting Xu (discussant), and Elira Kuka, Jared Rubin, and Danila Serra through the Adopt-a-Paper program. We also thank seminar and conference participants at Harvard, UCLA, Yale University, Berkeley Haas, University of British Columbia, University of Michigan, George Washington University, Auburn University, Wilfrid Lauriel University, University of Oxford, LUISS, Universitá di Bologna, Universitá di Padova, University of Melbourne, Tsinghua University, the NBER Summer Institute on Productivity, Development and Entrepreneurship, the Cliometrics Conference, the NBER Productivity Lunch, the Second Women in International Economics (WIE) Conference, the AFA, the CEPR/LEAP Workshop in Development Economics, the Barcelona GSE Summer Forum on the Economics of Science and Innovation, the Pacific Conference for Development Economics, the Webinar Series in Finance and Development (WEFIDEV), the LSE Asia Economic History Seminar, the Online Economic History Workshop, and the Ridge Conference for helpful comments and discussion. We are also thankful to senior officials at Statistics China for declassifying the historical data for this research and to historians at the National Archives Administration of China for their help in accessing archival materials. The views expressed herein are those of the authors and do not necessarily reflect the views of the National Bureau of Economic Research.

NBER working papers are circulated for discussion and comment purposes. They have not been peer-reviewed or been subject to the review by the NBER Board of Directors that accompanies official NBER publications.

(C) 2021 by Michela Giorcelli and Bo Li. All rights reserved. Short sections of text, not to exceed two paragraphs, may be quoted without explicit permission provided that full credit, including (C) notice, is given to the source. 
Technology Transfer and Early Industrial Development: Evidence from the Sino-Soviet Alliance Michela Giorcelli and Bo Li

NBER Working Paper No. 29455

November 2021, Revised January 2022

JEL No. L2,M2,N34,N64,O32,O33

\begin{abstract}
This paper studies the causal effect of technology and knowledge transfers on early industrial development. Between 1950 and 1957, the Soviet Union supported the "156 Projects" in China for building technologically advanced industrial facilities. We exploit idiosyncratic delays in project completion and the unexpected end of the Sino-Soviet Alliance, and show that receiving both Soviet technology and know-how had large, persistent effects on plant performance, while the effects of receiving only Soviet capital goods were short-lived. The intervention generated horizontal and vertical spillovers, and production reallocation from state-owned to privately owned companies since the late 1990s.
\end{abstract}

\author{
Michela Giorcelli \\ Department of Economics \\ University of California at Los Angeles \\ Bunche Hall 9262 \\ 315 Portola Plaza \\ Los Angeles, CA 90095 \\ and NBER \\ mgiorcelli@econ.ucla.edu \\ Bo Li \\ Tsinghua University \\ 43 Chengfu Rd \\ Beijing, China \\ 100083 \\ lib@pbcsf.tsinghua.edu.cn
}




\section{Introduction}

International technology and knowledge flows are key drivers of economic development. Numerous works have shown that the adoption of foreign technologies may lead to a substantial boost in firm productivity in less-advanced economies (Pavcnik, 2002; Goldberg et al., 2009; Bloom et al., 2013; Hardy and Jamie, 2020). Consequently, technology transfer interventions have been widely used to promote industrialization in developing countries (Hoekman et al., 2004; Robinson, 2009), especially through the diffusion of state-of-the-art capital goods (Stokey, 2020). However, in their early stages of industrialization, countries lack not only modern capital goods but also industry-specific knowledge that allows pioneering firms to succeed (Mostafa and Klepper, 2018). Acquiring this knowledge is complex: several of its elements are "tacit" or embodied in workers and organizations and are often obtained through extensive on-the-job training from foreign companies (Chandra, 2006).

Despite the importance of technology and knowledge transfer programs, little is known about which interventions work in fostering firm and industry growth in the first phases of a country industrialization. Moreover, which program components help firms move from adopting foreign technology to developing their own in not very well understood. The empirical research has been held back mostly by lack of long-term firm-level data and natural variation in the delivery of such interventions. Moreover, it is challenging to disentangle the effects of technology embedded in foreign capital goods from those of know-how diffusion and human capital training, as they often occur simultaneously.

This paper studies the causal effect of technology and knowledge transfers on early industrial development, using evidence from the Sino-Soviet Alliance. In the 1950s, to help the industrialization of the newly formed People's Republic of China, the Soviet Union supported the development of the so-called 156 Projects, an array of technologically advanced, large-scale, capital-intensive industrial facilities. ${ }^{1}$ Based on the initial agreements, the projects were supposed to receive a "basic" technology transfer that involved the duplication of whole Soviet plants through the provision of Soviet state-of-the-art machinery and equipment; and an "advanced" know-how and knowledge transfer via visits of Soviet experts to teach Chinese high-skilled technicians how to operate the new machineries, and to offer technical and industrial management training to the engineers and production supervisors. The Soviet transfer was considered a vital factor in Chinese development. Its investments, which accounted for $45 \%$ of Chinese GDP in 1949, allowed China to receive the best Soviet technology, which in the steel and iron industries was considered the best in the world (Lardy, 1995; Gangchalianke, 2002; Zhikai and Wu, 2002).

\footnotetext{
${ }^{1}$ We say "so-called" because 156 projects were originally contemplated and because the identifying label has persisted to this day in China. However, only 139 projects involving Soviet technology transfer were eventually signed and approved between 1950 and 1957.
} 
We use newly assembled data on the 156 Projects signed between 1950 and 1957, matched with declassified data on their plant performance yearly until 2000 for the steel industry and with firm-level data in 1985 and between 1998 and 2013 for all the industries.

Our identification strategy relies on idiosyncratic delays in project completion due to Soviet constraints in providing capital goods and experts to train their Chinese counterparts. When the Sino-Soviet Split in 1960 ended the alliance between the two countries, all the plants belonging to the 156 Projects had already been built, but only part of them had received the Soviet transfers. Specifically, some plants had received both Soviet machinery and equipment and technical assistance (advanced plants), some others had only gotten Soviet machinery and equipment (basic plants), while the remaining ones didn't get any Soviet machinery or technical assistance and ended up employing traditional domestic technology (comparison plants). Notably, basic, advanced and comparison plants had very similar observable characteristics, were located in comparable geographical areas, and operated in the same industries. Moreover, their outcomes were on the same trends in the five years before receiving the Soviet intervention.

We find three key results. First, using plant-level data for the steel industry from 1949 to 2000, we show that receiving a basic transfer had positive but short-lived effects on plant performance, while the impact of the advanced transfer was large and persistent. Output of basic plants differentially increased relative to that of comparison plants up to six years after receiving Soviet machineries, reaching a 14.7 percent peak. After that, the effects started slowly decreasing and were no longer significant after 20 years, the estimated like cycle of Soviet capital. By contrast, output of advanced plants rose by 19.7 percent within 20 years, relative to that of basic plants, reaching a cumulative effect of 49.5 percent after 40 years. Advanced plants also produced better-quality steel and were systematically more productive, while employing similar inputs to basic and comparison plants. Second, declassified firmlevel data in 1985 and between 1998 and 2013 in all industries confirm the short-lived impact of the basic transfer and the long-lasting effect of the advanced transfer.

Third, we investigate why only the impact of the advanced transfer persisted over years. We show that, in the 1960s and 1970s, when China's interaction with foreign countries was extremely limited, only advanced plants were able to develop new production processes and home-fabricate modern machineries and equipment, which ultimately replaced Soviet capital when it became obsolete. Moreover, once China began gradually opening to international trade since 1978, advanced plants relied dramatically less on the import of foreign capital, and they systematically engaged more in trade due to producing better-quality output than basic and comparison plants. By contrast, we do not find evidence that our results are driven by special ex-post government favors to advanced or basic plants, by better political connections, or by selection on unobservable plant characteristics. 
The major goal of the Soviet technology transfer was to create large industrial facilities to push local industrial development. Was the program successful in doing so? We document that the existence of positive spillovers was largely related to the presence of advanced plants. Both plants in the same firms of advanced plants and plants in other firms horizontally and vertically related to them increased their production and their productivity, relative to similar plants related to basic plants, adopted the same technology of the advanced plants when China was a closed economy, and followed their export patterns when China opened up to international trade. Conversely, these variables did not differentially change between plants related to basic and comparison plants.

Starting in the late 1990s, the Chinese government undertook a number of market liberalization reforms. We therefore test if the spillover effects persisted after this major institutional change. We find that, between 1998 and 2013, firms that became privately owned and were economically related to advanced plants had better performance and were more productive. At the county-level, these changes were associated to an increased share of industrial output produced by private firms. The main driver of these results seem to be the fact that counties that hosted advanced plants had a higher concentration of industryspecific human capital. In fact, advanced plants offered training programs for engineers and created professional schools for high-skilled technicians that were institutionalized over years (Hirata, 2018). In the long run, counties that hosted advanced plants were more likely to offer STEM degrees and had higher number of technical schools relative to counties that hosted basic plants, that may have helped firms to hire better educated workers when they started competing for inputs in the local labor market.

Finally, we assess the contribution of the Soviet transfer to the Chinese aggregate growth rate between 1950 and 2008. An additional basic project increased province-level output on average by 1.1 percent per year, and an additional advanced project by 6.2 percent. A back-of-the-envelope calculation shows that, without the basic and the advanced transfer, Chinese real GDP per capita growth between 1953 and 1978 would have been between 7 and 19 percent lower, confirming their vital importance in Chinese industrialization.

The contribution of this paper is threefold. First, our paper relates to the growing literature examining the effects of industrial policies and technology transfer on structural transformations. Several works have shown the importance of investments in heavy industries to foster early stage economic development and their positive long-run consequences (Mitrunen, 2019; Choi and Levchenko, 2021; Kim et al., 2021; Lane, 2021). Our work contributes to this strand by comparing large industrial facilities that use foreign-imported technologies to similar plants that rely on domestic capital goods, and by disentangling the effects of technology transfers embodied in physical capital goods relative to the tacit human capital component that accompanies such transfers. Our context is China, which 
experienced the "the fastest sustained expansion by a major economy in history" (Morrison, 2019). Moreover, by showing that knowledge diffusion and on-the-job training are essential for ensuring persistent effects of industrial policies, our paper also related to the literature that studies the role of foreign firms in seeding industry-specific know-how that can subsequently push the growth of a developing country's industry (Mostafa and Klepper, 2018; Keller and Yeaple, 2013; Yeaple, 2013).

Second, we contribute to the literature that studies the role of technology diffusion in developing countries (see Verhoogen, 2020 for a comprehensive review). Previous papers have documented the positive impact of technology adoption on short-run performance of small and medium-sized firms (Pavcnik, 2002; Mel et al., 2008; Goldberg et al., 2010; Bloom et al., 2013; Bruhn et al., 2018; Hardy and Jamie, 2020) and the existence of substantial barriers to its adoption (Atkin et al., 2017; Bloom et al., 2020; Juhász et al., 2020). To the best of our knowledge, this paper is the first to use nonexperimental data to examine the effects of international technology and knowledge transfer on the largest industrial facilities of a country, following them from their foundation to recent times.

Third, this work is related to the large literature on spillover effects. Existing research has focused on spillovers determined by foreign direct investments and the opening of large new plants (Javorcik, 2004; Javorcik et al., 2008; Greenstone et al., 2010; Alfaro-Urena et al., 2019), worker mobility (Stoyanov and Zubanov, 2012), managerial knowledge diffusion (Bloom et al., 2020; Bianchi and Giorcelli, 2022), and sectoral industrial policies (Liu, 2019; Fan and Zou, 2021; Lane, 2021). Our setting allows us to disentangle the spillover effects of technology transfer from knowledge spillovers that follow know-how diffusion, and their interactions with major institutional changes. In terms of context, a closely related paper is Heblich et al. (2020) that also studies the Sino-Soviet technology transfer. However, they focus on long-run negative spillovers of the 156 Projects on counties that hosted them, relative to counties suitable to host them that were eventually not selected. By contrast, our paper looks at differences within the 156 Projects, using plant-level data and assessing short, medium and long-run direct effects and spillover effects.

The rest of this paper is organized as follows. Section 2 describes the Sino-Soviet Alliance. Section 3 describes the data. Section 4 discusses the empirical framework and the identification strategy. Section 5 studies the effects of the technology transfer on firm-level outcomes. Sections 6 and 7 examine the spillover and aggregate effects. Section 8 concludes. 


\section{The Sino-Soviet Alliance and Technology Transfer}

\subsection{The Birth of the Sino-Soviet Alliance}

With the end of WWII, a bipolar international order emerged, dominated by the confrontation and competition between the United States and the Soviet Union. For both powers, a strategic alliance with China was crucially important (Lardy, 1995). Since 1927, China had been intermittently enmeshed in a civil war fought between the Kuomintang-led government of the Republic of China (ROC) and the Communist Party of China. The U.S. government supported the Kuomintang and the government of the ROC by providing military, economic, and political assistance, ${ }^{2}$ but in 1949, the Communist Party emerged as victorious. China's war came to an end, and the People's Republic of China (PRC) was formed. Despite some initial Soviet distrust, the PRC's inspired principles and economic system provided the ideological basis for cooperation with the Soviet Union. On February 14, 1950, the two countries signed the "Sino-Soviet Treaty of Friendship, Alliance, and Mutual Assistance," which marked the start of large-scale economic and military cooperation and the Soviet Union's official recognition of the PRC as a strategic partner (Zhang et al., 2006). In response to the Sino-Soviet Alliance, the United States and its allies imposed economic sanctions against the PRC in the 1950s and stopped all trade activities with the country until 1978.

\subsection{The Soviet Technology Transfer Setup}

At the end of China's civil war, the country's economy was largely premodern. Almost two-thirds of output was agricultural, less than one-fifth industrial, and the few industrial factories built during the Japanese occupation had been destroyed during WWII bombing (Lardy, 1995, p. 144). The newly formed government adopted a centralized, plannedeconomy model, based on state ownership of all economic activities and large collective units in agriculture (Perkins, 2014). Market forces were largely eliminated, and industrial inputs and outputs were allocated according to quotas established by subsequent Five-Year Plans. Wages were set by the government, which allocated workers to jobs.

The First Five-Year Plan (1953-1957) declared that one of the new government's major goals was to build a modern industrial system. However, the country lacked technical knowledge and expertise to do so on its own. Several Chinese leaders admitted that, "[...] at the beginning [they] didn't quite understand what should be done first and what should

\footnotetext{
${ }^{2}$ On December 16, 1945, U.S. President Truman described the policy of the United States with respect to China as follows: "It is the firm belief of this government that a strong, united, and democratic China is of the utmost importance to the success of the United Nations Organization and for world peace" (United States of America Government Printing Office, 1945, p. 945).
} 
be done later in industrial development, and how to coordinate various departments given limited inputs" (Ji, 2019). Therefore, PRC officials pressed hard for technology transfer from the Soviet Union (Zhang et al., 2006, p. 110). Between 1950 and 1957, the two countries signed various agreements for the construction of the 156 Projects. These projects focused on heavy industries, such as metallurgy, machinery, electricity, coal, petroleum, and chemical raw materials - the Chinese government was intending to mimic the development model of the Soviet Union in the 1930s. The total value of such investments amounted to $\$ 80$ billion (in 2020 figures; $\$ 20.2$ billion in 1955 RMB), equivalent to $45.7 \%$ of Chinese GDP in 1949 and $144.3 \%$ of its industrial output.

Through this program China received the most advanced technology available in the Soviet Union, which in industries like iron and steel was the best in the world (Gangchalianke, 2002). For instance, during the 1950s the Soviet Union built and operated the world's best blast furnaces - these were installed in Chinese plants in Anshan, Wuhan, and Paotou before even being employed in Soviet factories (Lardy, 1995; Zhikai and $\mathrm{Wu}, 2002){ }^{3}$ The advancement of Soviet technology was recognized from the US side as well. After studying the Soviet and Chinese industries for decades, Clark (1995) argued that Soviet steel technology transferred to China was comparable to that of the most developed Western economies. The Soviet effort in promoting Chinese management of the 156 Projects impressed the Indian Prime Minister Nehru. While visiting the Anshan plant, he compared the Soviet transfer in China with the British and US one in India, concluding that in China "the entire process of production in the enterprise [was] being operated by Chinese experts," while in India the British and Americans "never allow[ed] Indians to manage the most important mechanism of the enterprises" (Zhikai and $\mathrm{Wu}, 2002$; Hirata, 2018).

The locations for the 156 Projects were chosen based on geological conditions and access to natural resources. For example, experts from the Soviet Ministry of Metallurgy explained that the nonferrous metal plants, such as the Guizhou Aluminum Company, "must be built on copper rich ore," and that "the copper content of the ore should be tested during the site selection." Beyond the geological conditions, Chinese leaders had a strong preference for choosing inner regions and mountain areas to protect these plants from potential military attacks (Lardy, 1995). For these reasons, the 156 Projects were concentrated in the northeastern regions (Heilongjiang, Jilin, Liaoning) and the inner regions (Shaanxi, Shanxi, Gansu, and Hubei, Figure 1). Only 10 projects were built on sites where firms existed before 1949. These firms were almost completely destroyed during the Civil War and were no longer

\footnotetext{
3 The Soviet Union did not provide any aid in the form of grants; it lent China only $\$ 2.9$ billion (\$300 million in 1955 dollars ) in response to a Chinese request for 10 times that amount. This loan shall be used to "repay the Soviet Union's delivery of machinery and equipment [...]. China shall trade raw materials, tea, agricultural products at foreign exchange rates to repay principal and interest from December 31, 1954, to December 31, 1963" (Lardy, 1995). The prices of machinery, equipment, raw materials, and other commodities were calculated according to world market prices.
} 
able to produce; therefore, they were rebuilt from scratch (Hirata, 2018). In this respect, the Soviet assistance shaped the geographical distribution of Chinese industrialization, since before 1952 the few existing firms were almost all located in the coastal areas (Lardy, 1995).

Chinese leaders, and in particular Chairman Mao Zedong, initially envisioned two types of transfers for all the 156 Projects: a "basic" technology transfer and an "advanced" knowhow and knowledge transfer. More specifically, the "basic" technology transfer involved the duplication of whole Soviet plants, the provision of Soviet state-of-the-art machinery and equipment, as well as help in surveying geological conditions, selecting plant sites, directing plant construction, and supplying blueprints. The "advanced" know-how and knowledge transfer involved visits of Soviet experts to teach Chinese high-skilled technicians how to operate the new machineries, and to offer within-firm technical and industrial management training to the engineers and production supervisors. The engineer training included classes in math, physics, and chemistry, as well as lectures in organizational, technological, and planning methods. The supervisor training, based on "scientific management" principles, included operational-planning classes, instructions on assigning workers to the most appropriate tasks, and the introduction of quality-control methods (Clark, 1973). ${ }^{4}$ The Soviet experts were expected to spend on average three years in Chinese plants, sharing engineering designs, product designs, and other technical data (Zhang et al., 2006). ${ }^{5}$

However, the Soviet leaders cautioned the Chinese counterpart they could not commit to such a massive technology and knowledge transfer due to lack of resources. Nevertheless, they offered to provide technical assistance based on experts availability and to share 4,000 product designs to improve technological innovations, increase equipment operation rates and product quality, and decrease both production costs and the amount of raw materials used (Zhang et al., 2006; Hirata, 2018; Ji, 2019).

\subsection{Delays in the 156 Projects, and the Sino-Soviet Split}

Despite the promises of Soviet Union and the rosy picture of "Great Friendship" promulgated by the authorities, the 156 Projects suffered serious difficulties and experienced many more delays than initially predicted both by the Soviet and the Chinese sides. On the ground, machinery, equipment, and designs ordered from the Soviet Union almost always arrived or started operating later than planned, due to constraints on Soviet production capacity, lack of Soviet experts able to visit Chinese plants, and miscommunication between Soviet and

\footnotetext{
${ }^{4}$ Starting in the early 1930s, Soviet planners under Stalin selectively adopted the latest American management methods; they invited many Western companies, including the Ford Motor Company to invest in the Soviet Union (Hirata, 2018).

${ }^{5}$ Despite numerous references to Soviet technical personnel in the Chinese press, no reliable totals are available on the number of Soviet military and civilian specialists assigned to Communist China. According to the statistics recorded by the Soviet Ministry of Foreign Affairs, 5,092 Soviet technical personnel were working in China between 1952 and 1959.
} 
Chinese experts (Filatov, 1975; Hirata, 2018). The Soviet Union did not have machinery and equipment in reserve, and by 1955 almost every Soviet industrial area had received orders for capital goods from China that proved difficult to deliver (Zhang et al., 2006). Between 1955 and 1960, one-third of annual Soviet production of steel-rolling equipment was for China. Further complicating matters, the Sino-Soviet Alliance descended into turmoil in the late 1950s over political and ideological disputes. Despite attempting to maintain a bilateral relationship in the early 1960s, the two countries couldn't reach an agreement, and the formal end of their cooperation in 1963 became known as the Sino-Soviet Split. Long before that, the 156 Projects had already been dramatically reduced in scope and number. In 1960, the Soviet Union suddenly withdrew its experts from China and stopped providing machinery and equipment.

These practical and political matters strongly affected the completion of the 156 Projects. For instance, the Benxi Iron and Steel Company, built to replicate the Red October (Krasny Oktyabr) factory in Volvograd, was expected to receive Soviet machinery and equipment in 1955, but never got them. As this material was about to be shipped, a fire destroyed critical equipment in the Red October factory, which then blocked the shipment to Benxi. Soviet Union ensured that it would produce it later, after its plant operations could resume, but due to the Split this never happened (Filatov, 1975).

The lack sufficient numbers of experts to help oversee plant construction and installation of new machinery and equipment was also a major deal. For example, Soviet experts who were supposed to visit the Fushun Aluminum Plant in 1959 never did so - they were retained to deal with an unexpected breakdown in the Volkhov Aluminum Plant and by the time they finished this task the Split had occurred. As a consequence, Fushun eventually received Soviet machinery, but without any training despite what was initially planned between the two countries (Filatov, 1980).

Similarly, the language barriers between Soviet and Chinese teams required the constant presence of translators, but this, too, proved problematic. Soviet experts expected to visit the Changchun First Automotive Plant in 1955 had to wait until their translators learned Chinese, which prevented the Chinese plant from starting its operations on schedule (Borisov and Koloskov, 1980). Long-distance bilingual communication fostered additional problems. When Soviet experts arrived at the Jilin Daheishan Molybdenum Mine Plant, they realized their designs did not fit, as the initial written communication was misunderstood and letters requesting additional clarifications went lost (Kiselev, 1960). The attempts of providing the new designs failed due to the upcoming Split.

In light of these delays even before the Split, it would have been profitable for China to prioritize the most promising projects, but the country faced many challenges in doing so. In fact, each project was unique, aimed at replicating a specific Soviet plant, which made 
it impossible to reallocate machinery or equipment across the 156 Projects (Filatov, 1975). And unfortunately, the Soviet experts who did arrive in China were proficient only in the use of specific machinery and their translators had been trained in project-specific terminology, which limited their employment to the projects they were initially allocated to (Borisov and Koloskov, 1980).

Consequently, the Chinese government decided to start plant operations with domestic capital goods and replace them with Soviet machineries as soon as they were delivered. For this reason, in 1960, when the Split occurred, all the plants belonging to the 156 Projects were already been built and were producing. However, they largely differed for the technologies in use. In fact, some plants had received both Soviet machinery and equipment that replaced domestic capital and technical assistance, and some others had only gotten Soviet machinery and equipment. The remaining ones didn't get any Soviet machinery or technical assistance and continued producing with domestic capital (Clark, 1973). The country's limited access to the foreign technology market after 1950 forced it to rely solely on its own resources until at least 1978.

In the rest of the paper we will refer to projects and plants that got both Soviet machinery and equipment and technical assistance as advanced projects or advanced plants; to projects and plants that got only Soviet machinery and equipment as basic projects or basic plants; and to projects and plants that didn't get any Soviet machinery or technical assistance as comparison projects or comparison plants.

\section{Data}

We collected and digitized different types of historical and administrative data from primary sources. In this section, we document our data-collection process and describe the data collected. Additional details and definitions of the variables appear in Appendix B.

\subsection{The 156 Projects}

We started our data collection by compiling a list of the 156 Projects envisioned under the Sino-Soviet Alliance, from the official agreements between the Soviet Union and the PRC stored at the National Archives Administration of China. As previously mentioned, while initial discussions between Chinese and Soviet leaders aimed at 156 Projects, the number of civil projects signed and approved between 1950 and 1957 was 139. For each project, we collected detailed information on its name and location, the name of the plant built, industry, size and capacity.

Of the 139 approved projects, 46 were basic projects, 47 were advanced projects and 
46 were comparison projects (Table 1, columns 5-7). Most projects were located in China's northeastern and interior regions, for strategic reasons and for proximity to natural resources, and only 10 (7.1\%) were built on the site of plants existing before 1949 and destroyed during the Civil War (Figure 1). The projects called for the construction of large industrial plants; each employing on average 39,910 workers, for a total of around 5.5 million workers - a mere 3 percent of China's total workforce, but almost 40 percent of the country's employment in the industrial sector in 1952. The projects were overwhelmingly concentrated in heavy industries. The electricity sector accounted for $23.0 \%$ projects, the machinery sector for $21.6 \%$, the coal sector for $20.1 \%$, and the steel and nonferrous metal industries for $14.4 \%$ and $10.1 \%$, respectively (Figure A.1). Only two projects (1.4\%) were in light industry. The average planned investment amounted to $\$ 580.3$.4 million, and the projects' mean duration was expected to be 5.6 years (Table 1, column 1 ).

\subsection{Plant- and Firm-Level Data}

We manually collected and digitized restricted, plant-level annual reports compiled yearly by the Steel Association for the 94 steel firms operating in China from 1949 to 2000, for a total of 1,410 plants. The reports contain rich information on plant performance, such as quantity and type of steel products, utilization of inputs, capacity, the specific machinery in use, and number and types of workers (unskilled workers, high-skilled workers, and engineers). Using plant name, location, county, and province, we manually and uniquely matched the 304 steel plants across 20 firms belonging to the 156 Projects with their outcomes from the Steel Association reports. 91 plants received a basic transfer, 98 an advanced transfer and 115 did not get any Soviet transfer (Table 2, columns 1-3).

A natural question is whether plant performance data that represent the core of our analysis are accurate. For instance, plant supervisors may have had incentives to misreport some data to meet the goals set by the central government or to show better-than-actual performance. To attenuate this concern, we assert three points. First, the Steel Association reports were highly monitored and checked by industry peers, which strongly limited the possibility of manipulation. Moreover, the officially-released aggregate production data was complied by Statistics China, a different and independent source. Manipulations were therefore more likely to occur in the latter rather than in the former reports. Second, after the Sino-Soviet Split, the Chinese government wanted to tie up loose ends with the Soviet Union as quickly as possible. ${ }^{6}$ Therefore, if any manipulation occurred, it should have aimed at underestimating rather than overestimating the impact of the Soviet technology transfer,

\footnotetext{
${ }^{6}$ For instance, China rushed to repay Soviet immediately, even though it could have done so over ten years (Zhang et al., 2006).
} 
especially in the long run. This would go against us finding results. ${ }^{7}$ Third, we cross-check our data with several sources. In particular, we rely on the studies of the US Professor Gardner Clark, who examined the Chinese steel industry between 1949 and 1993, by visiting over multiple trips Chinese steel plants with the goal of assessing the quality of capital they were using (Clark, 1995). His works conclude that the data from the Steel Association Reports, our main source, appear credible. ${ }^{8}$ More details about our data cross-check can be found in Appendix B.

We also manually collected and digitized confidential, firm-level data from the Second Industrial Survey, conducted by Statistics China in 1985 and declassified for this project. This survey is the first and the most comprehensive dataset on Chinese industrial enterprises between 1949 and the early 1990s. It covers more than 40 industries within the industrial sector, containing firm-level data for the 7,592 largest firms operating in China in 1985. The survey gathered data on each firm's output, sales, profits, fixed assets, raw materials, total wages, number of employees, finished product inventory, main products, production equipment, and year of establishment. Using name, location, and province, we manually and uniquely matched all 139 firms that were part of the 156 Projects to their performance in 1985. From the Survey, we also collected and digitized county-level and prefecture-level industrial production data. ${ }^{9}$

Finally, we manually matched all 139 firms in the 156 Projects with their 1998-2013 performance from the China Industrial Enterprises database. This database, compiled yearly from 1998 to 2013, covers more than 1 million public and private industrial enterprises above a designated size in China. ${ }^{10}$ It includes a rich set of information on firms: firm output, number of employees, and profits, as well as ownership structure and capital investment.

\subsection{Statistical Yearbooks}

We manually collected and digitized province-level data on GDP, population, capital, investment, and number of workers from the Statistical Yearbooks compiled yearly between 1949 and 2000 by Statistics China. These data confirm that the PRC was little industrialized in 1950. The average share per province of firms in the agricultural sector was $85 \%$, accounting for $80 \%$ of total provincial output. By contrast, the share of provincial output in

\footnotetext{
${ }^{7}$ For instance, during the Great Leap Forward, the Chinese government wanted to show the efficacy of labor-intensive methods of industrialization, which would emphasize manpower rather than machines and capital expenditure, in stark contrast with the goals of the Soviet transfer (Clark, 1973; Lardy, 1995).

${ }^{8}$ More specifically, in Table B.1, we repeat our main analysis using Clark (1995)'s data, which lead to results fully consistent with our main findings.

${ }^{9}$ Counties are Chinese administrative areas, comparable to U.S. counties. Provinces are Chinese administrative areas, comparable to U.S. states. Prefecture cities are Chinese administrative areas, larger than counties but smaller than states.

10 The data include firms whose asset value exceeds 5 million yuan prior to 2011, and 20 million yuan after 2011.
} 
heavy industries was less than 18\%. Between 1952 and 1985, Chinese economy experienced structural transformation: heavy industries uniformly increased their shares of production, at the expense of light industries (Figure A.2, Panel A).

As China adopted a planned-economy model, government control over industry dramatically increased. In 1952, $48.7 \%$ of the firms were privately owned, while state-owned corporations comprised only 20.2\%. By 1965, more than $90 \%$ of firms were state-owned (Figure A.3, Panel A). During the same period, the agriculture industry was commonly organized into state-controlled cooperatives. Also, the location of industrial activities gradually shifted from the coastal regions to the country's interior (Figure A.3, Panel B)-consistent with the fact that most of the 156 Projects were located in the interior regions for strategic reasons and for proximity to natural resources.

\section{Identification Strategy}

The identification strategy of this paper relies on the delays in completion of the 156 Projects that arose after their start. When in 1960 the Soviet Union suddenly interrupted the technology transfer program, some plants had received both Soviet machinery and equipment and technical assistance (advanced plants), some others had only gotten Soviet machinery and equipment (basic plants), while the remaining ones didn't get any Soviet machinery or technical assistance and ended up employing traditional domestic capital goods (comparison plants).

We estimate the effects of the Soviet technology transfer via the following equation on the 304 steel plants belonging to the 156 Projects:

$$
\begin{aligned}
\text { outcome }_{i t} & =\alpha_{i}+\delta_{t}+\sum_{\tau=-5}^{40} \beta_{t}\left(\text { Basic }_{i} \cdot \text { Years after Transfer }=\tau_{i t}\right) \\
& +\sum_{\tau=-5}^{40} \gamma_{t}\left(\text { Advanced }_{i} \cdot \text { Years after Transfer }=\tau_{i t}\right)+\epsilon_{i t}
\end{aligned}
$$

outcome $_{i t}$ is logged output and $\mathrm{TFP}^{11}$ of plant $i$ at time $t$; Basic $_{i}$ is an indicator for plants that received a basic transfer; Advanced $_{i}$ is an indicator for plants that received an advanced transfer on top of a basic transfer; Years after Transfer $=\tau_{i t}$ is an indicator when a calendar year is $\tau$ years before or after the year in which plant $i$ received the Soviet transfer. Since equation 1 is an event study, we need to impute values for Years after Transfer $=\tau_{i t}$ for comparison plants. To this end, we assume that they would have been treated in 1960, the year of the Spilt. However, our results are robust to alternative imputations, as explained in Section 5.1. The excluded year is $\tau=-1$. Plant

\footnotetext{
${ }^{11}$ Specifically, we compute either TFPQ or TFPR based on the possibility of measuring firm physical output or only revenues. Details about their estimation can be found in Appendix C.
} 
fixed effects $\alpha_{i}$ control for variation in output over plants that is constant over time. Calendar year fixed effects $\delta_{t}$ control for variation in output over time that is common across all plants. Standard errors are clustered at the plant level. As all plants were still alive and state-owned in 2013, equation 1 estimates an intensive margin effect.

Under the identification assumption that the transfer eventually received (or not received) by a plant was orthogonal to its characteristics or its potential success, the coefficient $\beta_{t}$ captures the effect of receiving a basic transfer on plant performance, relative to plants that did not receive any Soviet transfer $\tau$ years after its implementation; the coefficient $\gamma_{t}$ captures the additional effect of receiving an advanced transfer on top of a basic transfer $\tau$ years after its implementation. The remainder of this section provides evidence in support of the research strategy.

\subsection{Were Basic, Advanced and Comparison Projects Comparable at the Time of Approval?}

We test whether basic, advanced and comparison projects were comparable when they were signed and approved. To do so, we perform an ANOVA test for mean equality on several baseline project characteristics between the three groups. First, we compare the approval and start year of projects. In fact, projects that eventually received a basic or an advanced transfer may have been approved or started earlier than the comparison ones and so more likely to have been finished before the Split. However, we do not find significant differences among the three groups (Table 1, columns 5-8). Second, we check if comparison projects were more complex and therefore harder to complete before the Spit than the basic or the advanced ones. The ANOVA test fails to reject the hypothesis of mean equality between the three groups of projects in terms of planned and actual investment, the planned and actual number of workers, the value of equipment supposed to be received from Soviet Union, the expected project length, and the expected capacity. Similarly, the share of projects built on the site of firms destroyed during the Sino-Japanese war is substantially the same between basic, advanced and comparison projects. Finally, we test whether basic or advanced projects may have located in more accessible areas than the comparison projects. The difference in distance from national and provincial borders, the coast and Treated Ports where most economic activities were concentrated, and railroads and roads is not statistically different among them.

Despite the similarity in their observable characteristics, basic or advanced projects may have been concentrated in areas or sectors with an ex-ante higher potential to grow relative to the comparison projects. To rule out this hypothesis, we estimate the predicted probabilities (marginal effects) from a multinomial logit model, where the dependent variable - that takes different values for basic, advanced and comparison (baseline) projects - is regressed on a full set of province or industry fixed effects. None of the estimated coefficients is statistically significant (Figure 2, Panels $\mathrm{A}$ and $\mathrm{B})$. This indicates that projects in specific provinces or industries did not have a higher probability of receiving a basic or an advanced transfer, relative to the baseline of not receiving any 
Soviet transfer. ${ }^{12}$ Moreover, we test if counties in which basic, advanced and comparison projects were located were similar before the Soviet intervention. OLS regressions predicting county-level number of firms, population, employment share and government funding in 1953 do not show statistically significant differences among counties hosting the three groups of projects (Table A.1, columns 1-4).

Taken together, these results are fully consistent with the historical records that explain how project delays were caused by constraints on Soviet production capacity, limited supply of Soviet experts and translators, and miscommunication between the two countries' experts, but were not related to project-specific characteristics (Filatov, 1975; Hirata, 2018).

\subsection{Were Basic, Advanced and Comparison Plants Comparable be- fore Receiving the Soviet Transfers?}

We next check if basic, advanced and comparison plants were comparable the year before receiving the Soviet transfer, by regressing plant characteristics and outcomes on indicators for receiving a basic and an advanced transfer and a fully set of firm fixed effects. None of the twenty-six estimated coefficients, all small in magnitude, is statistically significant (Table 2, columns 4-5). We conclude that the three groups of plants were statistically equivalent before receiving the Soviet transfer.

\subsection{Were Basic, Advanced and Comparison Plants Comparable on the Same Trend before Receiving the Soviet Transfers?}

We test whether basic, advanced and comparison plants were on the same trend in the five years before receiving the Soviet transfer. We first estimate a constant linear time trend model in which we interact a constant linear trend with indicators for receiving a basic and an advanced transfer. The estimated coefficients are close to zero and not statistically significant (Table A.2). Moreover, the estimated coefficients on the indicators alone are not statistically different from zero in all the specifications, confirming the results of the balancing tests of Table 2 .

Second, we replace the linear time trend with a full set of indicators for each year before receiving the Soviet transfer and interaction of each indicator with indicators for receiving a basic and an advanced transfer. The estimated coefficients on the indication terms are small in magnitude and never statistically significant from zero (Table A.3). Moreover, some are positive and some are negative, confirming lack of any pattern. Finally, the $F$-statistics at the bottom of each panel indicate that we can never reject the null hypothesis that the interaction terms are jointly equal to zero.

These findings suggest that basic, advanced and comparison plants were following a similar trend in the five years before receiving the Soviet transfer.

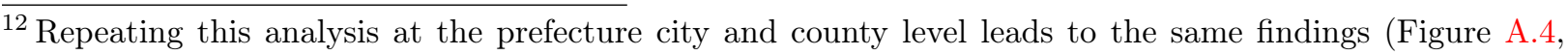
Panels A and B).
} 


\subsection{Were Resources Reallocated across Basic, Advanced and Com- parison Plants?}

A potential threat to our identification strategy arises if the Chinese government reallocated the Soviet machinery or workers from basic and advanced to comparison projects before or after the Split. First, it is worth noting that this scenario would go against us finding results. Second, since each project was aimed at replicating specific Soviet plants, China could not reallocate the Soviet machinery, equipment, experts, or translators to the most promising projects before the Split (Filatov, 1975). After the Split, the records on capital owned by plants indicate that basic and advanced plants did indeed retain the Soviet equipment. It would have been unprofitable for the government to temporarily shut down treated plants and replace brand-new machines, especially in light of the difficulties the country was facing in manufacturing capital goods on its own (Zeitz, 2011; Ji, 2019). Regarding the workforce, individual records to trace worker movement do not exist, to the best of our knowledge, but the historical records indicate that engineers in basic and advanced plants were employed to train other engineers, but only from nearby factories (Zhang et al., 2006; Hirata, 2018). Moreover, migration in China at that time was highly restricted thanks to the household registration (hukou) system, which made worker movements from basic and advanced to comparison plants extremely rare.

\section{Effects of Technology Transfer on Firm Performance}

In this section, we study the effect of the Soviet technology transfer on firm outcomes. For the steel industry, we have a plant-level panel dataset from 1949 to 2000. For the other industries, we use firm-level data in 1985 and between 1998 and 2013.

\subsection{Plant-Level Results in the Steel Industry}

The results of estimating equation 1 on plants in the steel industry indicate that receiving a basic transfer had positive but short-lived effects on plant performance, while the impact of the advanced transfer was large and persistent.

Output of basic plants was not significantly larger than that of comparison plants for the first two years after receiving Soviet machineries. It then started differentially growing, reaching a 14.7 percent higher level six years after the Soviet intervention. After that, the effects started slowly decreasing and were no longer significant after 20 years (Figure 3, Panel A). By contrast, output of advanced plants rose by 8.4 percent relative to that of basic plants within two years since the Soviet transfer and by 19.7 percent within 20 years. The gap between the two groups of plants continued to increase up to 40 years after the program, reaching a cumulative effect of 49.5 percent (Figure 3, Panel B). These findings are largely driven by the increased performance of basic and advanced plants, while output of comparison plants remained mostly flat during this time period (Figure 3, Panel C). 
Soviet technology transfer also affected the quality of steel. Relative to comparison plants that were using domestic blast furnaces, the introduction of open-hearth furnaces in basic plants increased the production of crude steel (considered the best-quality steel) and reduced the quantities of pig iron (considered of lower quality given its higher carbon content) up to 10 years. ${ }^{13}$ When the life-cycle of Soviet machineries estimated to be 15 years at the time ended, basic plants stopped producing higher-quality steel (Table A.4, columns 1-2). Conversely, the increase of crude steel and reduction in pig iron production in advanced plants remained systematically higher than in basic plants (Table A.4, columns 1-2). This outcome was likely due to the adoption of better production methods, that became embedded in firm organizations (Zhang et al., 2006). For instance, the adoption of Soviet methods of analysis that systematically sampled hot metals reduced the time to determine their chemical composition from 50 minutes to 2 minutes. This allowed necessary adjustments to be made more quickly, and led in turn to higher output quantity and quality in the short and in the long run (Clark, 1973).

We next investigate the effects of Soviet transfer on productivity. Specifically, we estimate total factor productivity quantity as $\log \mathrm{TFPQ}=\log \mathrm{TFPR}-\log \widetilde{p}$, where $\widetilde{p}$ is the revenue-share weighted average of the prices of plant products and total factor productivity revenue (TFPR) is calculated using Gandhi et al. (2020)'s method. The dynamic of productivity follows a similar pattern as output. Specifically, TFPQ of basic plants rose up to six years after Soviet transfer with a 14.5 percent increase relative to comparison plants, and was no longer significant after 20 years. Conversely, TFPQ of advanced plants increased between 8.3 percent two years after the Soviet transfer to $47.9 \%$ after 40 years, relative to basic plants (Figure 3, Panel B).

We further explore the increase in productivity by focusing on the different components of the production function. The increase in TFPQ appears to be driven largely by output growth, since inputs, such as number of worker and coke and iron quantities, were not statistically different between basic, advanced and comparison plants (Table A.4, columns 3-5). This also indicates that the government did not allocate more inputs to basic or advanced plants and therefore their increased performance is due to the Soviet transfer and not some other differential treatments.

A potential concern in interpreting the productivity results is that the Chinese economy was a noncompetitive environment until at least the late 1980s: all plants in a given industry faced the same prices in a given year. However, any non-market clearing prices set by the government would be absorbed by year fixed effects. Moreover, we do not have any bias due to unobservable plantspecific variation in output or input prices. Finally, as the steel sector is regarded as strategic by most governments, even in non-planned economies its production is subject to widespread industrial policy interventions, whose goals "do not necessarily coincide with value creation and profit maximization" (Mattera and Dilva, 2018). ${ }^{14}$

\footnotetext{
${ }^{13}$ Specifically, open-hearth furnaces facilitate the control of carbon content, by allowing period sampling and interim analysis of the heat, which is not possible with blast furnaces.

${ }^{14}$ It is worth noting that we can estimate a gross-output production function rather than a value-added production function. As explained in Gandhi et al. (2017), the percentage increase in value-added will be larger than in gross output, given the value of intermediate inputs that are not differentially changing in our context.
} 
Another issue may be that Chinese government-set prices may not be reliable indicators of underlying input quality, which may generate the so-called "quality bias." For instance, basic or advanced plants may have used the same quantity of better-quality inputs as comparison plants. We test for the possibility of quality bias as follows. First, we aggregate output and inputs using their average annual prices as reported by the American Iron and Steel Institute, and we compute TFPR and TFPQ with these values. The estimates using Chinese and U.S. prices are very similar in magnitude (Table C.2, column 2). Consistent with these results, the historical records indicate that Chinese prices indeed reflected quality differences. In 1985, for instance, Statistics China set the crude steel price at 320RMB (US\$199.22 in 2020 figures) per ton, compared to 249RMB (US\$154.95 in 2020 figures) per ton for pig iron. Second, following de Roux et al. (2020), who show that the transmission bias and the quality bias offset when the production function is estimated with naive OLS, we estimate TFPR and TFPQ with the OLS factor shares. The results are nearly identical to those that use our baseline estimation (Table C.2, column 3).

Robustness Checks. Our findings are robust to a variety of modifications to the baseline specification. Specifically, our results hold if we replace plant and year fixed effects with firm-year fixed effects and county-year fixed effects (Table A.5, columns 2, 3, 6, and 7). While regressions with plant and year fixed effects in the form of Equation 1 are widely used, a recent literature documents possible shortcomings of these two-way fixed effects specifications (De Chaisemartin and D'Haultfoeuille, 2020; Goodman-Bacon, 2021; Borusyak et al., 2021). In particular, Sun and Abraham (2021) explains that, in presence of heterogeneous treatment effects, the coefficients on the leads and lags of the treatment variable in an event study might place negative weights on the average treatment effects for certain groups and periods. To address this concern, we use an "interaction-weighted" (IW) estimators, as proposed by Sun and Abraham (2021) themselves, which is fully consistent with our baseline results (Table A.5, columns 4 and 8). We also impute values of Years after Transfer $=\tau_{i t}$ to comparison plants using the values of the first year or the average year in which basic and advanced plants received the Soviet transfer. The pattern and the magnitude of our results remain substantially unchanged (Table A.6, columns 2, 3, 5, and 6). Next, we propose different levels of standard-error clustering, that, in all cases, confirm the significance level of our main specification (Table A.7). Finally, to test for potential manipulation in our plant-level data, we use the estimates made by Clark (1995) that assessed the minimum and maximum possible levels of steel production, based on the capital in use in each steel plant. Even assuming that basic and advanced plants produced at the minimum and comparison plants at the maximum level, we would still find a persistent effect of the advanced transfer and a short-lived effect of the basic transfer, in line with our main results (Table B.1, columns 4-8). As noted in Section 3.2, Clark (1995) conclude that the data from the Steel Association Reports are accurate.

\subsection{Medium- and Long-Run Firm-Level Results in All Industries}

For 1985 and between 1998 and 2013, the availability of large-scale data allows us to match all the basic, advanced and comparison firms with their medium- and long-run economic outcomes. We 
estimate the following equation:

$$
\text { outcome }_{i t}=\alpha+\beta \cdot \operatorname{Basic}_{i}+\gamma \cdot \operatorname{Advanced}_{i}+\theta_{c s t}+\nu_{i t}
$$

where outcome $i t$ is value added, TFPR calculated using Gandhi et al. (2020)'s method and workers of firm $i$ at time $t$; Basic $_{i}$ is an indicator for firms that received a basic transfer; Advanced ${ }_{i}$ is an indicator for firms that received an advanced transfer on top of a basic transfer; and $\theta_{c s t}$ are county-sector-year fixed effects. Standard errors are clustered at the plant level. For estimation in 1985, we don't have a time dimension and we replace county-sector-year fixed effects with countysector fixed effects.

These estimates confirm our main results from the steel industry. In 1985 and between 1998 and 2013, value added, TFPR and employees of basic firms were not significantly different than those of comparison firms (Table A.8, columns 1, 3 and 5). By contrast, value added of advanced firms was, respectively, $41.5 \%$ and $52.0 \%$ higher than that of basic firms, and TFPR was $39.5 \%$ and $49.3 \%$ higher, with no differences in employment relative to basic plants (Table A.8, columns 2, 4 and 6). The magnitude of the estimates on the full sample are remarkably similar to those obtained from the steel-plant sample, which indicates that the Soviet technology transfer results apply beyond the steel industry.

\subsection{Mechanisms}

Why did the effects of advanced transfer persist over time, while the effects of basic transfer were short-lived? In this section, we examine potential mechanisms. We start our analysis by looking at production innovation and technology development. Between 1960 and until at least 1978, due to the Soviet Split and the embargo of Western countries, Chinese firms could rely only on their own resources to operate and innovate. During the 1960s, a new steel-making process, the basic oxygen, that blew oxygen through molten pig iron and lower the carbon content of the alloy, became predominant (Clark, 1973). According to the historical records, advanced plants were the only ones able to develop and adopt this process innovation (Ji, 2019). Data on production process in use by the steel plants indicate that, while basic plants were not more likely to use the basic oxygen process, advanced plants had a 25.2 percent higher probability of using it five years after the Soviet transfer and 65.1 percent higher probability twenty years after, relative to basic plants (Table 3, column 1). This finding is likely related to the organizational, technological, and planning classes advanced plants received, whose goal was to improve factory operations and develop new and more efficient production methods. It also explains why advanced plants produced more high-quality crude steel than basic plants and well beyond the life-cycle of the Soviet-imported machineries.

The Soviet capital was state-of-the-art in the 1950s and 1960s, but became obsolete in the 1970s and 1980s, due to the development of continuous casting furnaces (Fruehan et al., 1997). Data on capital adoption indicate that only advanced plants home-fabricated the continuous casting furnaces that were used to replace Soviet open-hearth ones. As a result, advanced plants were between 26.7 
and 78.4 percent more likely to use this type of furnaces relative to basic plants between 10 to 20 years after the Soviet transfer (Table 3, column 2). Conversely, basic plants did not show more continuous casting furnaces usage than comparison plants. This technological development may explain the long-lasting impact of the advanced transfer. While the effects of the basic transfer faded out twenty years after the Soviet intervention, when the estimated life-cycle of Soviet capital ended, advanced plants were able to replace it and continue striving.

In the late 1970s, China began gradually opening to international trade, especially with the Western world. Among other effects, this implied that Chinese plants could import machines from the United States and Western Europe and export their products there. In light of the domestic development of new technologies, advanced plants relied dramatically less than basic plants on the import of foreign capital. Nevertheless, they exported $45.5 \%$ more steel and produced $51.1 \%$ more steel above the international standards than basic plants (Table 3, columns 3-5). This finding indicates that the quality of steel produced by advanced plants was recognized not only in China, but also by the international steel market. By contrast, we do not observe differential imports of foreign capital and exports between basic and comparison plants. This aspect can also contribute to explain the short-lived effect of the basic transfer. When both types of plants could import foreign machineries, basic plants did no longer have a productivity advantage over comparison plants.

We next examine whether the composition of plant human capital can be a mechanism for longrun persistence. The composition of human capital in the three types of plants was similar at time of opening, as we have shown in our balancing tests (Table 2). However, over time, advanced plants opened training schools for high-skilled technicians and offered within-firm training programs to their engineers (Hirata, 2018; Ji, 2019). Consequently, advanced plants employed more engineers and high-skilled technicians and fewer low-skilled workers than basic plants, while the human capital composition did not differentially change between basic treated and comparison plants (Table 4, columns 1-3). Better human capital likely boosted plant productivity, allowing the effects of the advanced transfer to persist.

\subsection{Alternative Explanations for the Technology Transfer Effects}

Even if project delays represent a natural variation in the probability of receiving the Soviet transfer, it still may be the case that in subsequent years basic or advanced plants received special favors from the government that, in turn, allowed their performance to flourish. For instance, the government may have allocated more funds to basic or advanced plants or may have invested more in counties were these plants were located.

To investigate this potential issue, we first examine whether basic or advanced treated plants received any special funding from the government. We find the government did not allocate more transfers or granted more loans to basic or advanced plants relative to the comparison plants, neither in the short run nor in the long run (Table A.9, Panel A, columns 1-2). ${ }^{15}$ Moreover, we check

\footnotetext{
${ }^{15}$ While we can observe yearly loans and transfers only for plants in the steel industry, looking at these variables in all 139 plants in 1985 and between 1998 and 2013 confirms the lack of differential and transfers
} 
whether plants that received the Soviet transfer became more accessible to roads and railroads than comparison plants after the intervention, which may have contributed to their success. However, we find that the distance from railroads and roads, statistically indistinguishable at the time of the transfer, did not differentially change between the three groups of plants in the following decades (Table A.9, Panel A, columns 3-4).

Basic and advanced plants may have also become more politically connected than comparison plants over time, or perhaps better politicians were allocated to their administrative areas. To test this hypothesis, we collected data from the People's Daily Online database, which includes names, city and year of birth, and education of both the secretaries of the Municipal Party Committee and the mayors at the prefecture-city level from 1949 to 2018. The secretaries of the Municipal Party Committee were directly linked with the central government and were responsible for Party affairs within the city area and for strengthening the Party's leadership. In accordance with the instructions of the higher-level Party committee, they carried out the work of Party agenda in the region, and they set up political and legal committees, the Party Committee's organization department, and other departments. The mayors represented the local government and coordinated the work of the Municipal People's Congress, the municipal government, and the provincial government. We therefore test whether secretaries and mayors that worked where basic or advanced plants were located were more likely to be born or have studied locally or whether they were more educated than those who worked where comparison plants were located. Having studied in the same areas where where basic or advanced plants were located may reflect stronger links with local firm management, while we use years of education as a proxy for politician quality. None of these four measures is statistically different between basic, advanced and comparison plants in the 40 years after the Soviet transfer (Table A.10, columns 1-6), which suggests that political connections and politician quality remained comparable over time.

Next, we check whether counties in which basic or advanced plants were located received more transfers from the government than counties where comparison plants were located. We find that total investments, as well as investments in industries both related and unrelated to the 156 Projects, are not statistically different between the three groups of counties (Table A.11, columns 1-3). Similarly, the number of other industrial projects sponsored by the Chinese government after the Sino-Soviet Split and the overall length of railroads and roads are substantially the same (Table A.11, columns 4-5). ${ }^{16}$ Taken together, these results do not support that the government favored plants that received the Soviet transfer or the counties where they were located.

Since firm exit was virtually non-existent in China until the 1990s, one may wonder if the Chinese government artificially kept alive comparison plants after the Sino-Soviet Split. This does not seem to be the case, as comparison plants, in spite of eventually not receiving any Soviet transfer, performed better and were larger than the other steel plants not included in the 156 Projects

between basic, advanced and comparison plants (Table A.9, Panel B).

${ }^{16}$ Other industrial projects sponsored by the Chinese government after the Split include the Construction of the Third Front (TF), a massive yet short-lived industrialization campaign in China's underdeveloped hinterland between 1964 and 1972. Fan and Zou (2021) document that the TF had long-run positive aggregate effects on the local economy, regardless of the initial development level of the regions. 
(Table A.12). While these results do not have any causal interpretation, they may indicate that, even if comparison plants were completed by the Chinese government alone, Soviet help in their initial planning was still beneficial.

In Section 4, we showed that basic and advanced plants exhibited similar observable characteristics relative to comparison plants. However, a potential concern to our identification may be selection on unobservable characteristics. To address this issue, we use the methodology proposed by Oster (2019), which assumes that the correlation between treatment and unobservables is equal to the correlation between treatment and observables multiplied by a factor $\delta$. A treatment effect is robust to selection on unobservables if it does not change sign at $\delta=1$. This value of $\delta$ means that the degree of selection on observed variables is the same as that on unobserved variables. ${ }^{17}$ In Table A.13, we show that our estimates change little relative to our main results as we move from $\delta=0.1$ to $\delta=1$ (columns 2-6). In order to have our treatment effects no longer significant, the degree of selection on unobserved variables should be between 8 and 19 times larger than selection on observed variables, values that are implausible (Table A.13, column 7). Therefore, our results do not appear driven by selection on unobservables.

\section{Spillover Effects}

One goal of the Soviet technology transfer was to create large industrial facilities to push local industrial development. In this section, we examine whether the transfer was successful in doing so, as well as the types of short-run and long-run spillovers it generated.

\subsection{Spillovers across Plants within Firms}

After absorbing the content of the Soviet training, advanced steel plants could have experienced additional improvements by transmitting new acquired knowledge to other plants in the same firm. To capture these effects, we estimate the following equation

$$
\begin{gathered}
\text { outcome }_{j f t}=\alpha_{f t}+\beta_{1} \cdot \text { Basic }_{f}+\gamma_{1} \cdot \text { Advanced }_{f}+\beta_{2} \cdot\left(\text { Basic }_{f} \cdot \text { Post }_{t}\right)+ \\
\gamma_{2} \cdot\left(\text { Advanced }_{f} \cdot \text { Post }_{t}\right)+\beta_{3} \cdot\left(\text { Basic }_{f} \cdot \text { Post }_{t} \cdot{\text { Post } 1978_{t}}\right)+ \\
\gamma_{3} \cdot\left(\text { Advanced }_{f} \cdot \text { Post }_{t} \cdot \text { Post } 1978_{t}\right)+\eta_{j f t}
\end{gathered}
$$

where outcome $_{j f t}$ is one of the performance outcomes of of plant $j$ in firm $f$ at time $t$; Basic $_{f}$ is an indicator for plants in the same firms of plants that received a basic transfer; Advanced $_{f}$ is an indicator for plants in the same firms of plants that received an advanced transfer on top of a basic

\footnotetext{
${ }^{17}$ Specifically, Oster (2019) shows that a treatment effect is robust if it does not change sign at $\delta=1$ and $R_{\max }=1.3 \cdot \tilde{R}$, where $R_{\max }$ is the $\mathrm{R}$ squared of a hypothetical regression of the outcome on both observables and unobservables. $\tilde{R}$ is the $\mathrm{R}$ squared of a regression of the outcome on just the observables. Table A.14 shows sensitivity to $R_{\max }$.
} 
transfer; Post is an indicator for years after treated plants in firm $f$ received the Soviet transfer; Post 1978 is an indicator for years after 1978, when China opened up to international trade; and $\alpha_{f t}$ are firm-year fixed effects. Standard errors are block-bootstrapped at the firm level with 1,000 replications. We estimate equation 3 on the sample of plants not supposed to receive the Soviet transfer but already existing at the time of the Soviet intervention.o

The results support the existence of positive spillovers, mostly related to the advanced transfer. Before the Soviet transfer, we do not observe different performance among these plants: the coefficients on the Basic and Advanced indicators are not statistically significant (Table 5, columns 1-5). After the Soviet intervention, while steel plants in the same firm of basic plants did not perform better than steel plants in the same firm of comparison plants, steel plants in the same firm of advanced plants increased their production of steel by 24.9 percent and were 22.1 percent more productive, relative to steel plants in the same firm of basic plants (Table 5, columns 1-2). These findings are likely driven by the adoption of technologies developed by advanced plants. As indicated by the historical records (Lardy, 1995; Ji, 2019), advanced plants offered within-firm training programs thought which they shared their new technologies and better production methods. Consistently, we find that plants in the same firm of advanced plants were more likely to use basic oxygen process and continuous-casting furnaces when China was a closed economy, and, when the country opened up to trade, these plants exported significantly more and produced a higher quantity of steel above the international standards (Table 5, columns 3-6).

\subsection{Spillovers across Firms}

We next examine whether the Soviet transfer generated spillover effects on other firms operating either in the same sector or in related sectors of the 156 Projects.

Horizontal Spillovers. We assess horizontal spillovers by estimating equation 3 on steel firms in the same counties as basic, advanced and comparison plants, established before the Soviet transfers and by replacing firm-year fixed effects with county-year fixed effects. Steel plants in the same counties of advanced plants, comparable before the Soviet transfer, showed better performance relative to those in the same counties of basic plants after the intervention. Specifically, they produced $12.9 \%$ higher output and were $12.4 \%$ more productive (Table 6 , columns 1-2), were more likely to use basic oxygen converters and continuous-casting furnaces developed by advanced plants, and since 1978 they exported significantly more and produced a higher quantity of steel above the international standards. We do find evidence of positive horizontal spillovers from plants in the same counties of basic plants relative to comparison plants.

Vertical Spillovers. The Soviet technology transfer may have generated spillovers on firms in the supply chain of treated plants. To estimate these effects, first we identify steel-industry establishemnts in the supply chain of basic, advanced and comparison plants by using the inputoutput matrix provided by the National Bureau of Statistics of China (NBS; see Appendix B.4). Second, we estimate equation 3 on steel plants located in the same counties of basic, advanced and comparison plants in nonsteel sectors, using county-year fixed effects instead of firm-year fixed 
effects.

Being a steel plant in the same county of a nonsteel basic plant is associated with higher production relative to being in the same county of a nonsteel comparison plant. Compared to the latter, in the former the quantity of steel produced, comparable before the Soviet transfer, is 14.2 percent higher (Table 7, column 1). These findings are fully consistent with the increased production of basic plants, which in turn may have affected their supply chain. However, only plants in the same county of advanced plants experienced a productivity increase after the Split, estimated to be 14.1 percent, relative to plants in the same county of basic plants (Table 7, column 2). These companies are also the only ones to register an increase in the probability of using basic oxygen converters and continuous casting furnaces and that systematically engaged more in trade and produced more steel above the international standards (Table 7, columns 3-6). ${ }^{18}$ The higher quality of supplied inputs may have in turn helped the differential performance of advanced plants to persist over time.

Overall, the spillover analysis presented so far is consistent with the findings in Greenstone et al. (2010), who show that productivity spillovers generated by the Million Dollar Plants are related mainly to workers rather than to input and output flows. By contrast, competition spillovers appear limited. This is not surprising, given the booming Chinese demand for steel and the country's large labor supply, which could be easily reallocated from the agricultural sector to the industrial sector (Lardy, 1995).

\subsection{The Role of Institutional Reforms}

Starting in the late 1990s, the Chinese government undertook a number of market-liberalization reforms. The goal of these initiatives was to release resources that could be more profitably employed by privatizing state-owned firms (Hsieh and Song, 2015).

In Section 6.2 we showed that, in the steel industry until 2000, plants in the same counties and horizontally or vertically related to advanced plants outperformed plants in the same counties as basic or comparison plants. We therefore test if these effects persisted after market liberalization, extending our analysis to firms in all the industries between 1998 and 2013. The results indicate that firms in the same counties of advanced plants and horizontally or vertically related to them performed better in terms of value added, TFPR and exports than firms in the same counties related to basic plants only if they were privatized (Table 8, Panel A, columns 1-4). Moreover, new private firms that located in the same counties as advanced plants had an additional performance gain relative to new firms in counties that hosted basic and comparison plants. By contrast, firms which remained state-owned did no longer show a competitive advantage (Table 8, Panel A, columns 1-4). Similarly, private and state-owned firms in the same counties of basic and comparison plants did not show differential outcomes (Table 8, Panel A, columns 7-8). ${ }^{19}$

\footnotetext{
${ }^{18}$ In 1985, only firms in the same counties as advanced treated plants had higher TFPR (Table A.15, columns 1-2). Notably, the estimates in 1985 are close in magnitude to the estimates in the steel industry.

${ }^{19}$ It is worth noting that in industries not related to basic, advanced and comparison plants we do not observe any difference in performance among firms in the same counties (Table 8, Panel B).
} 
At the county-level, these changes were associated to an increased share of industrial output produced by private firms. Specifically, counties that hosted advanced plants had on average 16.6 percent more private firms relative to counties that hosted basic plants and 25.2 percent more privately-produced industrial output (Table A.16, columns 1 and 4). Conversely, there were no differences between counties that hosted basic plants and counties that hosted comparison plants.

Through which mechanisms the proximity to advanced plants drove these results? We first test if counties that hosted advanced plants had a higher concentration of industry-specific human capital. In fact, advanced plants offered training programs for engineers and created professional schools for high-skilled technicians that were institutionalized over years (Hirata, 2018). Consequently, we find that universities in counties that hosted advanced plants were 10.4 percent more likely to offer STEM (science, technology, engineering, and math) university degrees and had a 16.8 percent higher number of technical schools per inhabitant relative to counties that hosted basic plants (Table A.17, columns 1 and 2). This was associated to a 14.3 percent higher number of STEM college graduates and a 17.6 percent higher number of high-skilled workers over population (Table A.17, columns 3 and 4). When firms started competing for inputs in the local market, companies that became privately owned in counties that hosted advanced may have been able to hire these better educated workers, with positive effects on their performance.

Another potential mechanisms could be that the government may have invested more resources in counties that hosted advanced plants, allowing firms located there to perform better, despite the technology transfer. In Section 5.4, we showed that total investments, and investments in related and unrelated industries of the 156 Projects, were not statistically different between basic, advanced and comparison counties between 1949 and 2000 (Table A.11, columns 1-3), which suggests that this potential channel is not driving our results.

The findings documented in this section may seem at odd with those reported by Heblich et al. (2020), that by comparing counties where the 156 Projects were located with counties suitable to host them but that were not selected, find that the former had a significant productivity advantage that was fully eroded during the 1990s due to overspecialization and reduced innovation. However, we compare firms and counties that were selected to be part of the 156 Projects and eventually received different types of Soviet transfers or did not. Therefore, our results do not speak at the Chinese counties which did not host the 156 Projects. More in general, the goal of our work is to disentangle the direct and indirect effects of different types of foreign interventions at the firm level, rather than estimating the county long-run negative spillovers of large industrial facilities relative to counties not affected by industrial policy.

\section{Soviet Transfer and the Chinese Growth Miracle}

In the past 80 years, China has experienced "the fastest sustained expansion by a major economy in history" (Morrison, 2019). To what extent did the Soviet technology transfer contribute to such outstanding economic growth? 
First, we estimate the effects of the technology transfer projects on the long-run development of provinces in which they were located, by regressing province outcomes on the province share of basic and advanced out of total province projects interacted with an indicator for years after 1952, when the Soviet transfer started. A 1 percent increase in the share of basic or advanced projects increases the province average logged industrial output by 0.43 and 1.07 percent per year, respectively (Table A.18, Panel A, column 1). Considering that the average number of basic and advanced projects per province is 2.7 and 3.1, having an additional basic project increased the logged industrial output by 1.6 percent per year and having an additional advanced project by 4.7 percent. Similarly, an additional basic project is associated with 0.49 percent higher employment in the industrial sector and 1.1 percent GDP per capita. These values are 1.35 percent and 6.2 percent in response to an additional advanced project (Table A.18, Panel A, columns 2-3).

Second, we estimate the cross-sectional fiscal multiplier of the technology transfer investments on provincial real GDP, via the following equation:

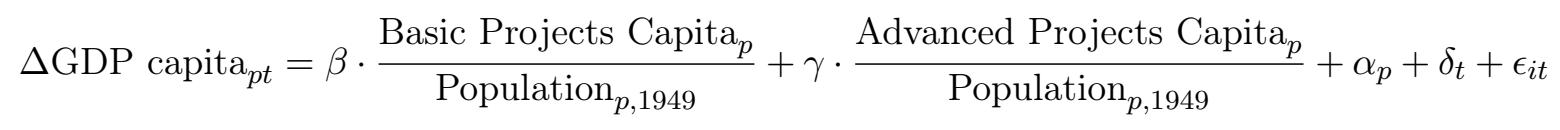

where $\Delta$ GDP capita $_{p t}$ is the change in real GDP per capita in province $p$ between year $t$ and year $t$ - 1 with $t \in[1949,2008]$; $\frac{\text { Basic Projects Capita }_{p}}{\text { Population }_{p, 1949}}$ and $\frac{\text { Advanced Projects Capita }_{p}}{\text { Population }_{p, 1949}}$ are respectively the amount of investments per capita in basic or advanced projects in province $p ; \alpha_{p}$ are province fixed effects; and $\delta_{t}$ are year fixed effects.

A province that got $\$ 1$ per capita more in basic transfers experienced an increase of $\$ 0.25$ in its real GDP per capita between 1949 and 1978, and $\$ 0.17$ between 1949 and 2008. A province that got $\$ 1$ per capita more in basic transfers experienced an increase of $\$ 0.58$ in its real GDP per capita between 1949 and 1978, and $\$ 0.51$ between 1949 and 2008 (Table A.18, Panel B, columns 1 and 3).

Next, we use our cross-sectional fiscal multiplier to assess the impact of the Soviet technology transfer on aggregate Chinese real GDP per capita. The cross-sectional multiplier does not necessarily coincide with the aggregate multiplier if the government responds to fiscal policy with monetary policy. Nakamura and Steinsson (2014) explains that a strict "leaning-against-the-wind" policy to address the inflationary effect of higher government spending can substantially decrease the aggregate multiplier. A leaning-against-the-wind policy could describe the Chinese monetary policy during the 1950s and 1960s, when containing inflation after the Chinese Civil War was one of the primary goals of the newly formed government (Lardy, 1995, p. 118). ${ }^{20}$ We therefore use the

\footnotetext{
${ }^{20}$ As explained in Chodorow-Reich (2019) and Guren et al. (2020), a potential concern in using a crosssectional multiplier to assess aggregate effects is that the cross-sectional multiplier measures outcomes in the treated area relative to the "contaminated" untreated area, violating the micro no-interference Stable Unit Treatment Value Assumption (SUTVA-micro). However, Chodorow-Reich (2019) shows that "in practical settings with geographic units of the size of U.S. states or smaller and demand shocks that do not induce factor mobility, SUTVA-micro violations should have minimal impact on general equilibrium effects and usually may be safely ignored" (p.2). These conditions are likely to hold in our setting, as Chinese provinces are comparable to U.S. states, and labor and capital could not be freely moved across the country.
} 
calibration in Nakamura and Steinsson (2014) and compute an aggregate multiplier equal to 0.06 between 1949 and 1978 and to 0.04 between 1949 and 2008 for basic projects, and to 0.14 between 1949 and 1978 and to 0.10 between 1949 and 2008 for advanced projects. ${ }^{21}$ We then perform a back-of-the-envelope calculation of the effects of the Soviet transfer on the national Chinese real GDP per capita growth rate. Specifically, we compute the effect of the Soviet transfer on real GDP growth as $\frac{N F M \text {-Basic Projects }}{Y}$ and $\frac{N F M \cdot \text { Advanced Projects }}{Y}$, where $N F M$ is the national fiscal multiplier, Basic Projects and Advanced Projects are the total value of the basic and advanced projects (24.19 billion and $\$ 25.85$ billion in 2020 figures respectively) and $Y$ is the Chinese GDP in 1952 (\$268.92 billion in 2020 figures). Therefore, without the basic transfer, the Chinese national real GDP growth rate would have been 0.56 percentage points lower in the medium run and 0.35 percentage points lower in the long run. Without the advanced transfer, the Chinese national real GDP growth rate would have been 1.33 percentage points lower in the medium run and 0.98 percentage points lower in the long run. Considering an average annual real GDP per capita growth rate of 7 percent between 1949 and 1978 and of 11.9 percent between 1949 and 2008, without the basic transfer such growth rates would have been 8 percent and 5 percent lower; without a basic transfer 19 percent and 14 percent lower. While these findings are fairly large, they are consistent with the historical evidence that considers the Soviet transfer as vital in Chinese early industrial development (Lardy, 1995; Zhang et al., 2006).

Moreover, we compute the return on investment of the Soviet transfer as the ratio between the benefits and costs of the technology transfer between 1953 and 1978. Using the estimate of the aggregate multiplier, we calculate that the Soviet transfer accounted for a average annual increase in nominal GDP of $\$ 4.7$ billion (in 2020 figures) during these 25 years. We compute the direct costs of the transfer as the sum of the total value of the basic and advanced projects (24.19 billion and $\$ 25.85$ billion in 2020 figures respectively) and the loan China received from Soviet Union and paid back in 10 years at an interest rate of 1\% (\$2.93 billion in 2020 figures). However, when the Chinese leaders decided to push industrial development, they did so at the expense of the agricultural sector, a decision later referred to as "lots of guns and not enough butter." We therefore estimate the opportunity costs of the transfer as the crowding out of the agricultural sector. Specifically, between 1952 and 1978, the agriculture sector's share of GDP decreased from $51 \%$ to $28.2 \%$, which corresponds to an average annual reduction of $\$ 2.6$ billion (in 2020 figures). Therefore, the benefits of the Soviet transfer were two times higher than the costs.

Finally, we compare the Soviet transfer in China to similar U.S. interventions in Western Europe. Specifically, the Marshall Plan's Productivity Program (1952-1958) provided technologically advanced U.S. capital goods and know-how to European firms that were a generation behind the U.S. firms (Silberman et al., 1996). In both cases, the human-capital component of such interventions was strongly linked to persistent results on firm outcomes (Bjarnar and Kipping, 2002; Giorcelli,

\footnotetext{
${ }^{21}$ Our calculation: $0.06=0.25 \times 0.24$, where 0.07 is our estimated medium-run cross-sectional multiplier for basic projects between 1949 and 1978 (Table A.18, column 1) and 0.24 comes from the ratio between 0.20 and 0.83 in Table 6, row 1, from Nakamura and Steinsson (2014). The same calculations apply to the other numbers.
} 
2019). In other words, human capital was the crucial ingredient for firms no matter the political situation they faced.

However, spillover effects of the Productivity Program were limited, in contrast with the substantial spillover effects the Soviet transfer generated. This could be explained by the fact that the Productivity Program targeted existing small and medium-sized firms that faced domestic and international competition, which may have discouraged them from sharing know-how with potential competitors (Fauri, 2006; Giorcelli, 2019). Conversely, China was an agricultural country, with limited trade opportunities, that could rely uniquely on Soviet assistance to foster its early-stage industrialization. The size of the new industrial facilities allowed them to exploit economies of scale from Soviet technology and to push agglomeration and spillover effects. Such effects were facilitated by know-how diffusion, which could flow across noncompetitor, state-owned firms. Finally, the Productivity Program did not attempt to change the pattern of European development, whereas the 156 Projects were located mostly in remote areas that would not otherwise have had great chances to industrialize.

\section{Conclusions}

This paper studies the effects of technology transfer on early industrial development. We collected data on the 156 Projects sponsored by the Soviet Union for the construction of technologically advanced, capital-intensive industrial facilities in China. To identify the causal effect, we rely on idiosyncratic delays in project completion, due to which some received Soviet technology while others were eventually realized by China alone with traditional domestic technology. The Soviet technology transfer had large and persistent effects on plant performance, and know-how diffusion further boosted firm outcomes. Since the late 1990s, the intervention has generated horizontal and vertical spillovers, as well as production reallocation from state-owned to privately owned companies.

What are the policy implications of this paper? In 1949, China was an agricultural country comparable to various developing countries today, where technology and knowledge transfers often occur through foreign direct investment and joint ventures (Robinson, 2009; Jiang et al., 2018). Our work shows that the effects of foreign-imported technologies are hard to replicate using domestic capital goods in early stages of economic development. Moreover, our findings underscore the importance of foreign on-the-job training and know-how, not only for improving firm performance and technology development but also for propagating industry knowledge to other companies, with the subsequent creation of industry-specific high-skilled human capital in the long run.

\section{References}

Alfaro-Urena, Alonso, Isabela Manelici, and Jose P. Vaquez, "The Effects of Joining Multinational Supply Chains: New Evidence from Firm-to-Firm Linkages," Working Paper, 2019.

Atkin, David, Azam Chaudhry, Shamyla Chaudry, Amit Khandelwal, and Erik Verhoogen, "Organizational Barriers to Technology Adoption: Evidence from Soccer-Ball Producers in Pakistan," Quarterly Journal of Economics, 2017, 132 (3), 1101-64. 
Bianchi, Nicola and Michela Giorcelli, "The Dynamics and Spillovers of Management Interventions: Evidence from the Training Within Industry Program," Journal of Political Economy, 2022, forthcomin.

Bjarnar, Ove and Matthias Kipping, The Americanization of European Business, Taylor Francis, 2002.

Bloom, Nicholas, Aprajit Mahajan, David McKenzie, and John Roberts, "Do Management Interventions Last? Evidence from India," American Economic Journal: Applied Economics, 2020, 12 (2), $198-219$.

_, Benn Eifert, Aprajit Mahajan, David Mckenzie, and John Roberts, "Does Management Matter? Evidence from India," Quarterly Journal of Economics, 2013, 128 (1), 1-51.

Borisov, Igor and Andrei Koloskov, The Sino-Soviet Relationship, Moscow: Mysl Publishing House, 1980.

Borusyak, Kirill, Xavier Jaravel, and Jann Spiess, "Revisiting Event Study Designs: Robust and Efficient Estimation," 2021.

Bruhn, Miriam, Dean Karlan, and Antoinette Schoar, "The Impact of Consulting Services on Small and Medium Enterprises: Evidence from a Randomized Trial in Mexico," Journal of Political Economy, 2018, 126 (2), 635-687.

Cameron, A. Colin, Jonah B. Gelbach, and Douglas L. Miller, "Bootstrap-Based Improvements for Inference with Clustered Errors," Review of Economics and Statistics, 2008, 90 (3), 414-27.

Chandra, Vandana, Technology, Adaptation, and Exports : How Some Developing Countries Got It Right, Washington, DC: World Bank Publications, 2006.

Chodorow-Reich, Gabriel, "Geographic Cross-Sectional Fiscal Spending Multipliers: What Have We Learned?," American Economic Journal: Economic Policy, 2019, 11 (2), 1-34.

Choi, Jaeo and Andri Levchenko, "The Long-Term Effects of Industrial Policy," 2021.

Clark, Gardner, Development of China's Steel Industry and Soviet Technical Aid, Cornerll University, 1973 . ,"The Chinese Steel Industry, 1949-1993," 1995.

De' Chaisemartin, Clément and Xavier D'Haultfoeuille, "Two-Way Fixed Effects Estimators with Heterogeneous Treatment Effects," American Economic Review, 2020, 110 (2964â96).

de Roux, Nicolas, Marcela Eslava, Santiago Franco, and Eric Verhoogen, "Estimating Production Functions in Differentiated-Product Industries with Quantity Information and External Instruments," NBER Working Paper, 2020, 28323.

Fan, Jingting and Ben Zou, "Industrialization from Scratch: The "Construction of Third Front" and Local Economic Development in China's Hinterland," Journal of Development Economics, 2021, (forthcoming).

Fauri, Francesca, Il Piano Marshall e l'Italia, Il Mulino, 2006.

Filatov, Leonid, "Scientific and Technical Cooperation between the USSR and China, 1949-1966," Newsletter Soviet-Chinese Relations, 1975, 65.

_, The Economic Evaluation on the Scientific and Technological Assistance from Soviet Union to China, Moscow: Soviet Union Science Press, 1980.

Fruehan, Richard J., Dany A. Cheij, and David M. Vislosky, "Factors Influencing Innovation and Competitiveness in the Steel Industry," 1997.

Gandhi, Amit, Salvador Navarro, and David A. Rivers, "How Heterogeneous is Productivity? A Comparison of Gross Output and Value Added," CHCP Working Paper, 2017, 27.

_ , _ , and _ , "On the Identification of Gross Output Production Functions," Journal of Political Economy, 2020, 128 (8), 2973-3016.

Gangchalianke, Igor, The Military Factors in the Separation between Soviet Union and China 2002.

Giorcelli, Michela, "The Long-Term Effects of Management and Technology Transfers," American Economic Review, 2019, 109 (1), 121-55.

Goldberg, Pinelopi K., Amit K. Khandelwal, Nina Pavcnik, and Petia Topalova, "Trade Liberalization and New Imported Inputs," American Economic Review, 2009, 99 (2), 494-500.

$\ldots, \ldots, \ldots$, and _ , "Imported Intermediate Inputs and Domestic Product Growth: Evidence from India," Quarterly Journal of Economics, 2010, 125 (4), 1727-67.

Goodman-Bacon, Andrew, "Difference-in-Differences with Variation in Treatment Timing," Journal of Econometrics, 2021, 225 (2).

Greenstone, Michael, Richard Hornbeck, and Enrico Moretti, "Identifying Agglomeration Spillovers: Evidence from Winners and Losers of Large Plant Openings," Journal of Political Economy, 2010, 118 (3), 536-598.

Guren, Adam, Alisdair McKay, Emi Nakamura, and Jón Steinsson, "What Do We Learn from Cross-Regional Empirical Estimates in Macroeconomics," NBER Macroeconomics Annual, 2020, pp. 175223

Hardy, Morgan and McCasland Jamie, "It Takes Two: Experimental Evidence on the Determinants of Technology Diffusion," Journal of Development Economics, 2020, forthcoming.

Heblich, Stephan, Marlong Seror, Hao Xu, and Yanos Zylbergberg, "Industrial Clusters in the Long Run: Evidence from Million-Rouble Plants in China," Working Paper, 2020.

Hirata, Koji, "Steel Metropolis: Industrial Manchuria and the Making of Chinese Socialism, 1916-1964." PhD dissertation 2018.

Hoekman, Bernard M., Keith E. Maskus, and Kamal Saggi, "Transfer of Technology to Developing Countries: Unilateral and Multilater Policy Options," World Bank Policy Research Working Paper 3332, 2004.

Hsieh, Chang-Tai and Zheng Michael Song, "Grasp the Large, Let Go of the Small: The Transformation of the State Sector in China," Brookings Papers on Economic Activity, 2015, 2, 295-34. 
Javorcik, Beata Smarzynska, "Does Foreign Direct Investment Increase the Productivity of Domestic Firms? In Search of Spillovers through Backward Linkages," American Economic Review, 2004, 94 (3), $605-27$.

_, Wolfgang Keller, and James Tybout, "Openness and Industrial Response in a Wal-Mart World: A Case Study of Mexican Soaps, Detergents and Surfactant Producers," World Economy, 2008, 31 (12), $1558-80$

Ji, Siyou, The Memoirs of Workers at Ansteel, Metallurgical Industry Press, 2019.

Jiang, Kun, Wolfgang Keller, Larry D. Qiu, and William Ridley, "International Joint Ventures and Internal vs. External Technology Transfer: Evidence from China," 2018.

Juhász, Réka, Mara P Squicciarini, and Nico Voigtländer, "Technology Adoption and Productivity Growth: Evidence from Industrialization in France," Working Paper, 2020.

Keller, Wolfgang and Stephen Ross Yeaple, "The Gravity of Knowledge," American Economic Review, 2013, 103 (4), 1414-44.

Kim, Minho, Munseob Lee, and Yongseok Shin, "The Plant-Level View of an Industrial Policy: the Korean Heavy Industry Drive of 1973," 2021.

Kiselev, Igor, "Soviet-Chinese Scientific Ties," in "The History of Science and Technology in Eastern Countries," Soviet Union Science Press, 1960.

Lane, Nathan, "Manufacturing Revolutions: Industrial Policy and Industrialization in South Korea," 2021, Working Pa.

Lardy, Nicholas, "Emulating the Soviet Model, 1949-1957," in Roderick MacFarquhar and John K. Fairbank, eds., The Cambridge History of China. Volume 14. The People's Republic of China: the Emergence of Revolutionary China, 1949-1965., Cambridge: Cambridge University Press, 1995, p. 722.

Liu, Ernest, "Industrial Policies in Production Networks," Quarterly Journal of Economics, 2019, 134 (4), $1883-1948$.

Mattera, Gianpiero and Filipe Dilva, "State Enterprises in the Steel Sector," Technical Report, OECD 2018.

Mel, Suresh De, David Mckenzie, and Christopher Woodruff, "Returns to Capital in Microenterprises: Evidence from a Field Experiment," Quarterly Journal of Economics, 2008, 123 (4), 1329-72.

Mitrunen, Matti, "Structural Change and Intergenerational Mobility: Evidence from the Finnish War Reparations," Working Paper, 2019.

Morrison, Wayne M., "China's Economic Rise: History, Trends, Challenges, and Implications for the United States," Technical Report, Congressional Research Service RL33534 2019.

Mostafa, Romel and Steven Klepper, "Industrial Development Through Tacit Knowledge Seeding: Evidence from the Bangladesh Garment Industry," Management Science, 2018, 64 (2), 495-981.

Nakamura, Emi and Jón Steinsson, "Fiscal Stimulus in a Monetary Union: Evidence from U.S. Regions," American Economic Review, 2014, 104 (3), 753-792.

Oster, Emily, "Unobservable Selection and Coefficient Stability: Theory and Evidence," Journal of Business Economic Statistics, 2019, 37 (2), 187-204.

Pavcnik, Nina, "Trade Liberalization, Exit, and Productivity Improvements: Evidence from Chilean Plants," Review of Economic Studies, 2002, 69 (1), 245-276.

Perkins, Dwight H., "The Centrally Planned Command Economy (1949â84)," in Gregory C. Chow and Dwight H. Perkins, eds., Routledge Handbook of the Chinese Economy, Routledge, 2014, p. 372.

Robinson, James A., "Industrial Policy and Development: A Political Economy Perspective," 2009 World Bank ABCDE Conference Papers and Proceedings, 2009.

Silberman, James M., Charles Weiss, and Mark Dutz, "Marshall Plan Productivity Assistance: A Unique Program of Mass Technology Transfer and a Precedent for the Former Soviet Union," Technology in Science, 1996, 18 (4), 443-460.

Stokey, Nancy, "Technology Diffusion," NBER Working Paper, 2020, 27466.

Stoyanov, Andrey and Nikolay Zubanov, "Productivity Spillovers across Firms through Worker Mobility," American Economic Journal: Applied Economics, 2012, 4 (2), 168-98.

Sun, Liyang and Sarah Abraham, "Estimating Dynamic Treatment Effects in Event Studies with Heterogeneous Treatment Effects," Journal of Econometrics, 2021, 225 (1), 175-99.

United States of America Government Printing Office, The Department of State Bulletin. Dir. of Publ. Department of State. 16.12.1945, Vol. XIII, Washington: US Government Printing Office, 1945.

Verhoogen, Eric, "Firm-Level Upgrading in Developing Countries," CDEPâCGEG WP, $2020,83$.

Yeaple, Stephen Ross, "The Multinational Firm," Annual Review of Economics, 2013, 5, $193-217$.

Zeitz, Peter, "Trade in Equipment and Capital Quality: Evidence from the Sino-Soviet Split." PhD dissertation 2011.

Zhang, Baichun, Jiuchun Zhang, and Fang Yao, "Technology Transfer form the Soviet Union to the People's Republic of China, 1949-1966," Comparative Technology Transfer and Society, 2006, 4 (2), $105-71$.

Zhikai, Dong and Jiang Wu, The Foundation of Industrialization, internal p ed. 2002. 
Figures and Tables

Figure 1: Distribution of the 156 Projects

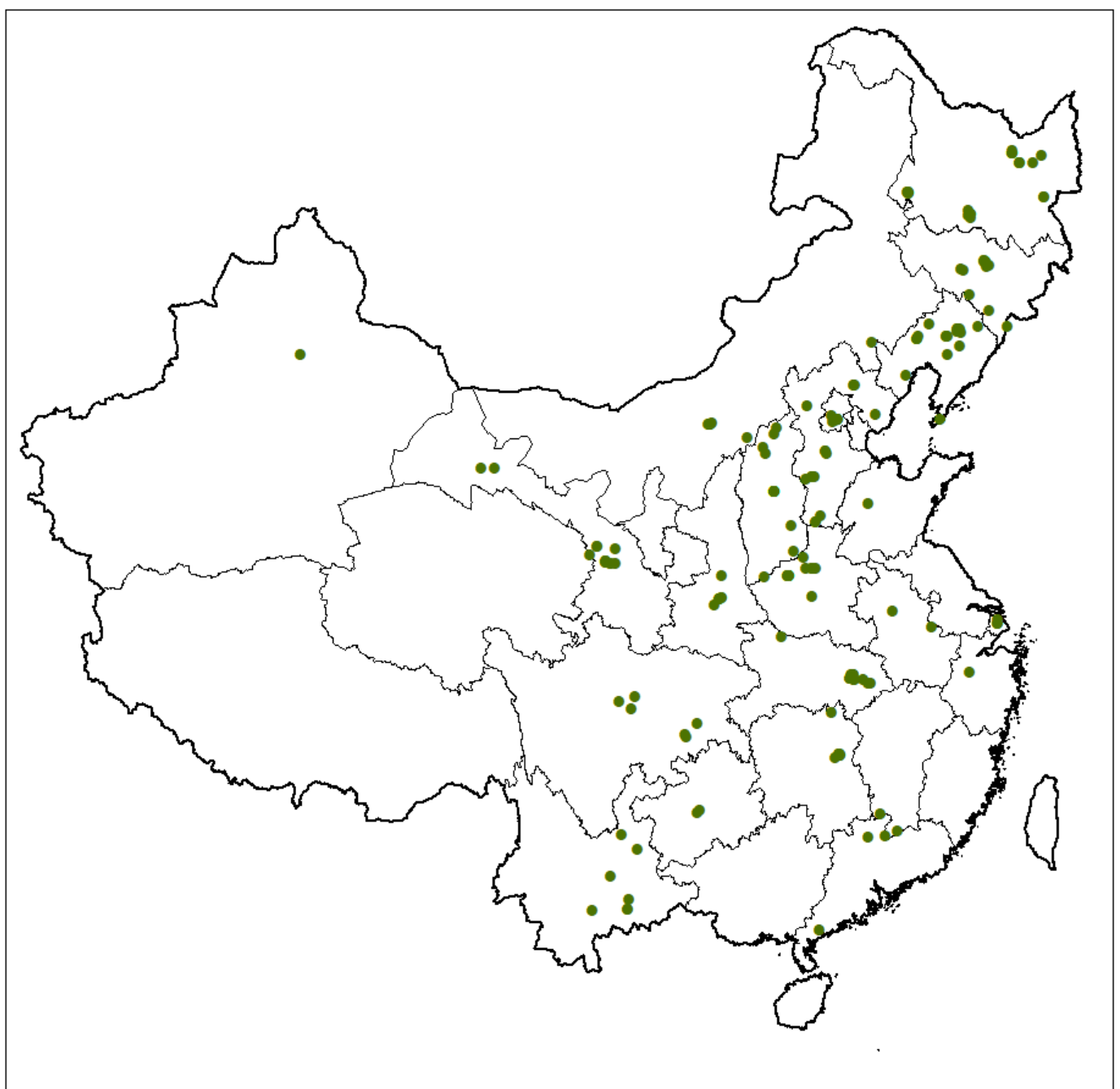

Notes. 139 approved projects between 1950 and 1957, although the iconic label 156 Projects refers to the number of projects initially contemplated. Data are provided at the project level from the National Archives Administration of China. 
Figure 2: Probability of Receiving Technology Transfer by Industries and Provinces

Panel A: Industry

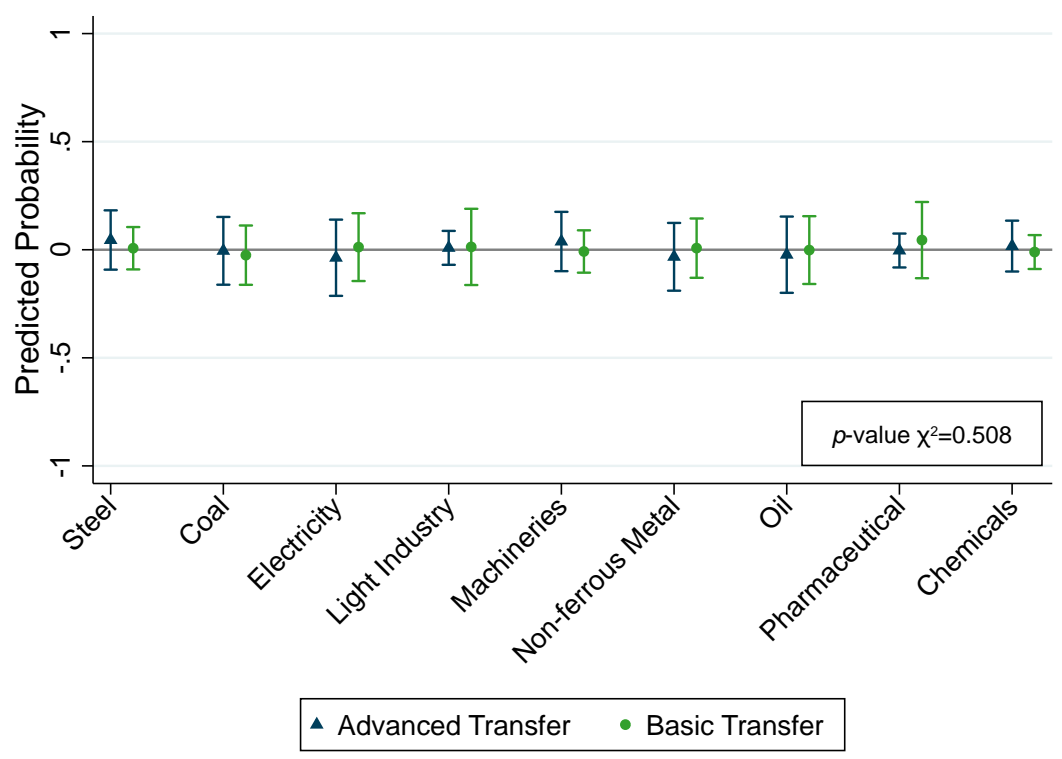

Panel B: Province

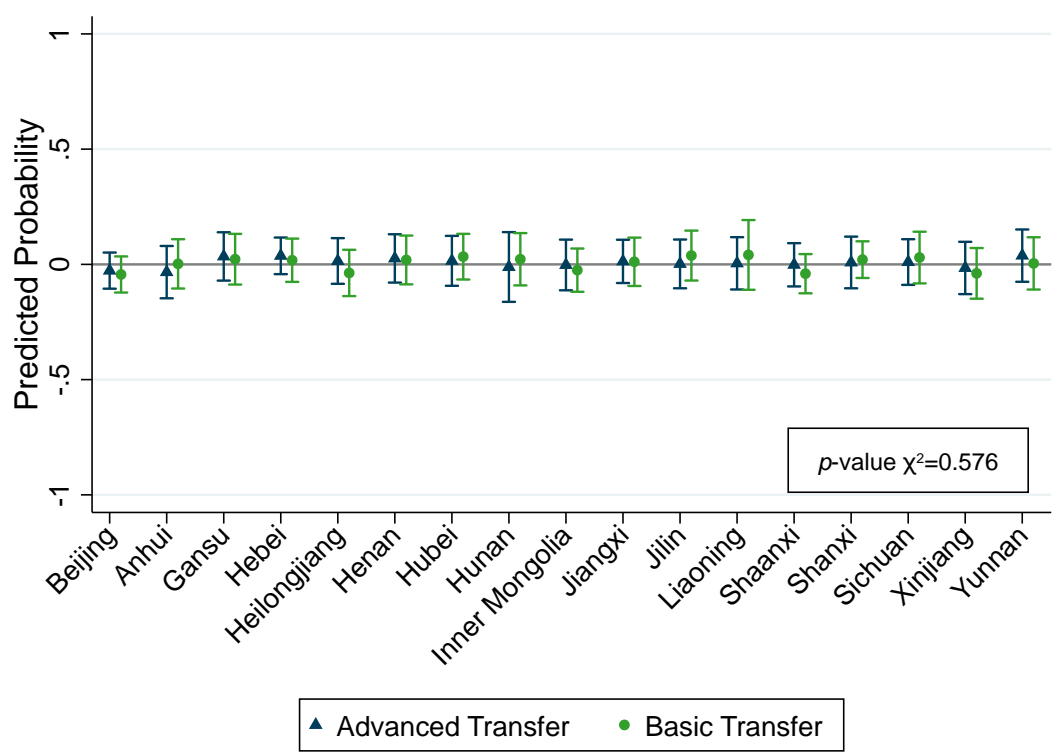

Notes. Predicted probabilities (marginal effects) of receiving a basic or an advanced transfer relative to the baseline of not receiving any Soviet transfer and $95 \%$ confidence intervals, estimated from the multinominal $\operatorname{logit} \log \left(\frac{\operatorname{Pr}\left(\operatorname{Transfer}_{i}=j\right)}{\operatorname{Pr}\left(\operatorname{Comparison~}_{i}\right)}\right)=\alpha+\psi_{s}+\epsilon_{i}$ in Panel A and from the multinominal $\operatorname{logit} \log \left(\frac{\operatorname{Pr}\left(\operatorname{Transfer}_{i}=j\right)}{\operatorname{Pr}\left(\operatorname{Comparison}_{i}\right)}\right)=$ $\alpha+\theta_{p}+\nu_{i}$ in Panel B, where $\psi_{s}$ are project sector fixed effects and $\theta_{p}$ are project province fixed effects. $p$-values of $\chi^{2}$ test of joint equality of all coefficients to zero are reported in each panel. Data are provided at the project level from the National Archives Administration of China. 
Figure 3: Yearly Effects of the Technology Transfer on Plant Output and TFPQ

\section{Panel A: Output}
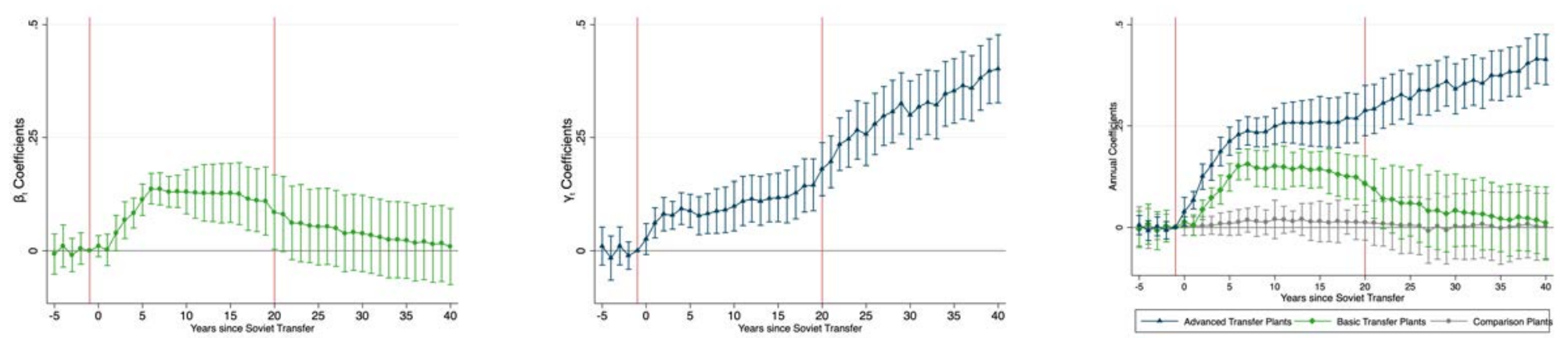

\section{Panel B: TFPQ}
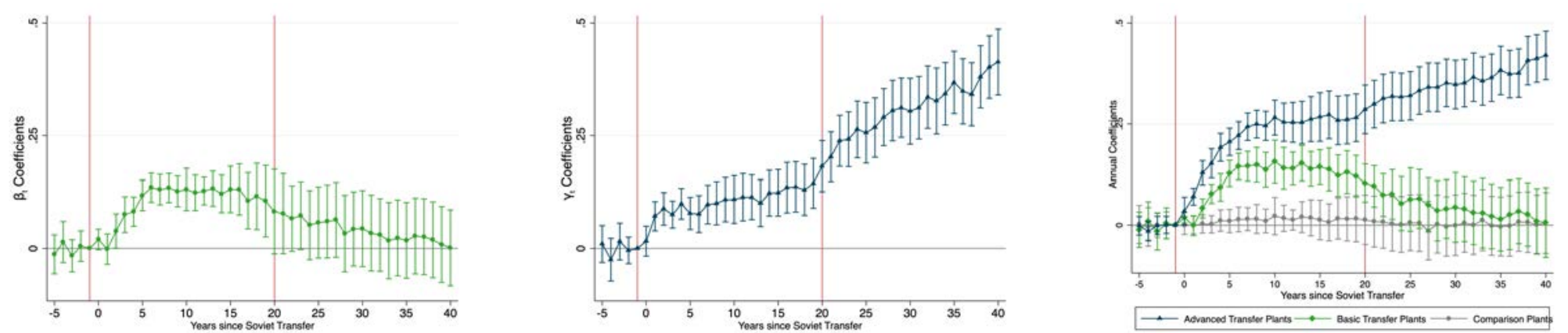

Notes. Annual $\beta_{t}$ coefficients (Panel A), $\gamma_{t}$ coefficients (Panel B) from Equation 1, and single differences (Panel C) for 304 steel plants belonging to the 156 Proejcts. Data are provided at the plant level from the Steel Association Reports from 1949 to 2000. Output is logged quantities (in million tons) of steel (Panel A). $T F P Q$ is $\operatorname{logged}$ total factory productivity quantity, computed as $\log T F P Q=\log T F P R-\tilde{p}$, where $\widetilde{p}$ is the revenue-share weighted average of the prices of plant products, and TFPR is calculated using Gandhi et al. (2020)'s method (Panel B). The first vertical line identifies the beginning of the Soviet transfer. The second vertical line identifies China's opening to international trade. Standard errors are clustered at the plant level. ${ }^{* * *} \mathrm{p}<0.01,{ }^{* *} \mathrm{p}<0.05,{ }^{*} \mathrm{p}<0.1$ 
Table 1: The 156 Projects

\begin{tabular}{|c|c|c|c|c|c|c|c|c|}
\hline & \multicolumn{4}{|c|}{ All Projects } & \multirow{2}{*}{$\begin{array}{c}\text { Basic } \\
\text { Mean } \\
(5) \\
\end{array}$} & \multirow{2}{*}{$\begin{array}{c}\text { Advanced } \\
\text { Mean } \\
(6)\end{array}$} & \multirow{2}{*}{$\begin{array}{c}\text { Comparison } \\
\text { Mean } \\
(7)\end{array}$} & \multirow{2}{*}{$\begin{array}{c}p \text {-value } \\
(8)\end{array}$} \\
\hline & $\begin{array}{c}\text { Mean } \\
(1)\end{array}$ & $\begin{array}{l}\text { SD } \\
(2) \\
\end{array}$ & $\begin{array}{c}\text { Min } \\
(3)\end{array}$ & $\begin{array}{c}\operatorname{Max} \\
(4) \\
\end{array}$ & & & & \\
\hline Approval Year & 1953.42 & 1.48 & 1950 & 1957 & 1953.57 & 1953.44 & 1953.26 & 0.609 \\
\hline Start Year & 1955.22 & 1.11 & 1952.77 & 1957 & 1955.24 & 1955.3 & 1955.13 & 0.762 \\
\hline Planned Investment (m) & 580.34 & 224.14 & 80.03 & 1074.29 & 594.08 & 577.97 & 569.02 & 0.864 \\
\hline Actual Investment (m) & 549.76 & 215.89 & 91.87 & 1077.83 & 526.99 & 550.67 & 571.59 & 0.615 \\
\hline Expected Equipment Value (m) & 259.35 & 49.76 & 139.79 & 435.39 & 259.01 & 260.05 & 258.98 & 0.993 \\
\hline Planned N. Workers (k) & 39.91 & 14.1 & 25.8 & 70.61 & 38.72 & 40.19 & 40.81 & 0.768 \\
\hline Actual N. Workers (k) & 39.65 & 14.66 & 23.64 & 69.82 & 39.94 & 40.05 & 38.95 & 0.924 \\
\hline Expected Length & 5.64 & 1.39 & 2 & 8 & 5.77 & 5.54 & 5.63 & 0.720 \\
\hline Expected Capacity (m tons) & 1.67 & 1.68 & 0.4 & 7.33 & 1.63 & 1.69 & 1.71 & 0.934 \\
\hline Existing Firm & 0.07 & 0.26 & 0 & 1 & 0.09 & 0.06 & 0.07 & 0.892 \\
\hline Distance Border (km) & 219.04 & 124.22 & 0.3 & 530.5 & 237.5 & 193.93 & 226.23 & 0.214 \\
\hline Distance Province $(\mathrm{km})$ & 68.71 & 36.39 & 0.3 & 152.41 & 66.6 & 69.78 & 69.72 & 0.893 \\
\hline Distance Coast $(\mathrm{km})$ & 544.34 & 245.44 & 5.26 & 1107.24 & 518.73 & 572.23 & 541.45 & 0.576 \\
\hline Distance Treated Ports $(\mathrm{km})$ & 563.06 & 288.98 & 5.26 & 1278.61 & 587.4 & 525.96 & 576.61 & 0.552 \\
\hline Distance Highway $(\mathrm{km})$ & 42.47 & 40.97 & 0.4 & 149.44 & 39.76 & 45.98 & 41.6 & 0.756 \\
\hline Distance Railway (km) & 60.98 & 76.67 & 0.1 & 369.75 & 62.65 & 59.77 & 60.55 & 0.983 \\
\hline Observations & 139 & 139 & 139 & 139 & 46 & 47 & 46 & 139 \\
\hline
\end{tabular}

Notes. Summary statistics for the 139 approved projects between 1950 and 1957, although the iconic label 156 Projects refers to the number of projects initially contemplated. Data are provided at the project level from the National Archives Administration of China. Columns 1-4 present, respectively, mean, standard deviation, minimum and maximum of characteristics of all the 139 approved projects. Columns 5, 6, and 7 report the mean of the same variables separately for 46 projects that received a basic transfer (Soviet machinery and equipment), 47 projects that received an advanced transfer (Soviet machinery and equipment and technical assistance) and 46 comparison projects that did not receive neither Soviet machinery and equipment nor technical assistance. Column 8 reports the $p$-value of an ANOVA test of mean equality among basic, advanced and comparison projects. Approval and Start Year are the approval and start year of each project; Planned, Actual Investment and Expected Equipment Value are, respectively, the investment planned at the approval time, the investment eventually realized, and the value of the equipment a project was expecting to receive from Soviet Union, measured in 2020 US\$ millions, reevaluated at 1 RMB in $1955=3.9605$ USD in 2020; Planned and Actual N. Workers is number of plant planned and actual employees, in thousands; Expected Length is the expected project length in years; Expected Capacity is the capacity planned at the approval time of each project, measured in 10,000 tons per kilowatt; Existing Firms is an indicator for projects built on the same site of already existing plants destroyed during the Chinese Civil War; Distance Border, Province, Coast, Treated Ports, Highway and Railway are the project distance in km from the nation border, province border, coast, Treated Ports, highway, and railway as in 1952. 
Table 2: Balancing Tests for Basic, Advanced and Comparison Steel Plants

\begin{tabular}{lccccc}
\hline \hline & & Mean $(1-3)$ & \multicolumn{2}{c}{ Difference (4-5) } \\
& Basic & Advanced & Comparison & Basic & Advanced \\
& $(1)$ & $(2)$ & $(3)$ & $(4)$ & $(5)$ \\
\hline Steel Production (m tons) & 604.24 & 602.06 & 602.85 & 2.038 & 7.022 \\
& $(18.67)$ & $(19.43)$ & $(23.67)$ & $(7.714)$ & $(7.669)$ \\
Crude Steel Production (m tons) & 152.82 & 153.49 & 154.62 & 7.814 & -1.293 \\
& $(14.18)$ & $(13.98)$ & $(14.23)$ & $(5.216)$ & $(5.678)$ \\
Pig Iron Production (m tons) & 101.04 & 96.08 & 99.31 & 1.999 & 0.262 \\
& $(15.70)$ & $(15.18)$ & $(15.12)$ & $(5.393)$ & $(5.533)$ \\
Current Assets (m) & 17.96 & 17.84 & 19.10 & -0.550 & 0.458 \\
Annual Sales (m) & $(2.09)$ & $(2.82)$ & $(2.08)$ & $(0.664)$ & $(0.903)$ \\
Value Added (m) & 17.18 & 17.83 & 18.04 & -0.655 & 0.893 \\
Productivity (log TFPQ) & $(3.56)$ & $(3.30)$ & $(2.45)$ & $(1.146)$ & $(1.081)$ \\
Employees per Plant (k) & 2.53 & 2.59 & 2.51 & -0.058 & 0.039 \\
Transfers & $(0.27)$ & $(0.16)$ & $(0.20)$ & $(0.112)$ & $(0.068)$ \\
Engineers (k) & 1.28 & 1.21 & 1.25 & 0.179 & -0.128 \\
High-Skilled Technicians (k) & $(0.55)$ & $(0.32)$ & $(0.25)$ & $(0.185)$ & $(0.135)$ \\
Unskilled Workers (k) & 6.60 & 6.49 & 6.44 & 0.110 & 0.242 \\
& $(0.72)$ & $(1.03)$ & 0.83 & $(0.280)$ & $(0.296)$ \\
& 0.36 & 0.38 & 0.37 & 0.002 & 0.016 \\
& $(0.05)$ & $(0.04)$ & $(0.05)$ & $(0.021)$ & $(0.021)$ \\
& 2.17 & 2.31 & 2.42 & -0.207 & -0.104 \\
& $(0.36)$ & $(0.14)$ & $(0.33)$ & $(0.134)$ & $(0.095)$ \\
& 3.94 & 3.9 & 4.02 & -0.156 & 0.065 \\
& 0.75 & 1.05 & 0.91 & $(0.337)$ & $(0.345)$ \\
& 5.43 & 5.24 & 5.09 & 0.673 & 0.534 \\
& $(1.86)$ & $(0.96)$ & $(2.18)$ & $(0.587)$ & $(0.459)$ \\
& 4.37 & 4.10 & 3.96 & -0.197 & -0.274 \\
& $(2.15)$ & $(1.05)$ & $(2.12)$ & $(0.677)$ & $(0.502)$ \\
\hline
\end{tabular}

Notes. Balancing tests for 304 steel plants part belonging to the 156 Projects in the year before receiving the Soviet transfers. Data are provided at plant level from the Steel Association Reports. Columns 1-3 report mean and standard deviation (in parentheses) of characteristics and outcomes separately for 91 plants which received a basic transfer (Soviet machinery and equipment), 98 plants which received an advanced transfer (Soviet machinery and equipment and technical assistance), and 115 comparison plants that did not receive neither Soviet machinery and equipment nor technical assistance. Columns 4 and 5 report the coefficients estimated from regressing each plant variable on an indicator for receiving the basic transfer, an indicator for receiving the advanced transfer, and a full set of firm fixed effects (not reported). Steel, Crude Steel and Pig Iron Production are the in million tons. Current Assets, Annual Sales and Value Added are measured in 2020 US $\$$ millions, reevaluated at 1 RMB in $1955=3.9605$ USD in 2020; Productivity (logged TFPQ) is logged total factor productivity quantity, computed as $\log T F P Q=\log T F P R-\tilde{p}$, where $\widetilde{p}$ is the revenueshare weighted average of the prices of plant products, and TFPR is calculated using Gandhi et al. (2020)'s method; Employees per plant, Engineers, High-Skilled Technicians, and Unskilled Workers are, respectively, thousands of employees, engineers, high-skilled technicians and unskilled workers; Loans and Transfers are, respectively, loans and free transfers that the government granted to each plant, measured in 2020 US\$ millions, reevaluated at $1 \mathrm{RMB}$ in $1955=3.9605$ USD in 2020. Standard errors are clustered at the plant level. ${ }^{* * *} \mathrm{p}<0.01,{ }^{* *} \mathrm{p}<0.05,{ }^{*} \mathrm{p}<0.1$. 
Table 3: Effects of Soviet Transfer on Technology Development

\begin{tabular}{|c|c|c|c|c|c|}
\hline & $\begin{array}{l}\text { Prob. Oxy. } \\
\text { (1) }\end{array}$ & $\begin{array}{c}\text { Prob. Cast. } \\
\text { (2) }\end{array}$ & $\begin{array}{c}\text { Log Import Capital } \\
(3)\end{array}$ & $\begin{array}{c}\text { Log Exports } \\
(4)\end{array}$ & $\begin{array}{c}\text { Log Int. St. } \\
(5)\end{array}$ \\
\hline Basic * Year 1 & $\begin{array}{c}0.006 \\
(0.005)\end{array}$ & $\begin{array}{c}0.005 \\
(0.009)\end{array}$ & $\begin{array}{c}0.002 \\
(0.006)\end{array}$ & $\begin{array}{c}0.001 \\
(0.004)\end{array}$ & $\begin{array}{c}0.005 \\
(0.007)\end{array}$ \\
\hline Basic * Year 5 & $\begin{array}{c}0.009 \\
(0.010)\end{array}$ & $\begin{array}{c}0.007 \\
(0.008)\end{array}$ & $\begin{array}{c}0.004 \\
(0.006)\end{array}$ & $\begin{array}{c}0.006 \\
(0.007)\end{array}$ & $\begin{array}{c}0.005 \\
(0.008)\end{array}$ \\
\hline Basic * Year 10 & $\begin{array}{c}0.009 \\
(0.010)\end{array}$ & $\begin{array}{c}0.006 \\
(0.008)\end{array}$ & $\begin{array}{c}0.003 \\
(0.004)\end{array}$ & $\begin{array}{c}0.008 \\
(0.011)\end{array}$ & $\begin{array}{l}0.006 \\
(0.012)\end{array}$ \\
\hline Basic * Year 20 & $\begin{array}{c}0.007 \\
(0.009)\end{array}$ & $\begin{array}{c}0.010 \\
(0.014)\end{array}$ & $\begin{array}{l}0.008 \\
(0.011)\end{array}$ & $\begin{array}{c}0.011 \\
(0.016)\end{array}$ & $\begin{array}{c}0.014 \\
(0.012)\end{array}$ \\
\hline Basic * Year 30 & $\begin{array}{c}0.007 \\
(0.009)\end{array}$ & $\begin{array}{c}0.011 \\
(0.015)\end{array}$ & $\begin{array}{l}0.007 \\
0.001\end{array}$ & $\begin{array}{l}0.006 \\
0.003\end{array}$ & $\begin{array}{l}0.004 \\
0.009\end{array}$ \\
\hline Basic * Year 40 & $\begin{array}{c}0.008 \\
(0.009)\end{array}$ & $\begin{array}{c}0.007 \\
(0.009)\end{array}$ & $\begin{array}{c}0.009 \\
(0.011)\end{array}$ & $\begin{array}{c}0.006 \\
(0.007)\end{array}$ & $\begin{array}{c}0.003 \\
(0.009)\end{array}$ \\
\hline Advanced $*$ Year 1 & $\begin{array}{c}0.003 \\
(0.010)\end{array}$ & $\begin{array}{l}0.008 \\
(0.011)\end{array}$ & $\begin{array}{l}0.006 \\
(0.008)\end{array}$ & $\begin{array}{l}0.005 \\
(0.007)\end{array}$ & $\begin{array}{l}0.004 \\
(0.006)\end{array}$ \\
\hline Advanced $*$ Year 5 & $\begin{array}{c}0.252^{* * *} \\
(0.041)\end{array}$ & $\begin{array}{c}0.019 \\
(0.013)\end{array}$ & $\begin{array}{l}0.007 \\
(0.011)\end{array}$ & $\begin{array}{c}0.003 \\
(0.006)\end{array}$ & $\begin{array}{l}0.007 \\
(0.009)\end{array}$ \\
\hline Advanced * Year 10 & $\begin{array}{c}0.345^{* * *} \\
(0.053)\end{array}$ & $\begin{array}{c}0.267^{* * *} \\
(0.051)\end{array}$ & $\begin{array}{c}0.009 \\
(0.011)\end{array}$ & $\begin{array}{c}0.004 \\
(0.006)\end{array}$ & $\begin{array}{c}0.002 \\
(0.0063)\end{array}$ \\
\hline Advanced * Year 20 & $\begin{array}{c}0.651^{* * *} \\
(0.151)\end{array}$ & $\begin{array}{c}0.784^{* * *} \\
(0.143)\end{array}$ & $\begin{array}{c}-0.059 * * * \\
(0.011)\end{array}$ & $\begin{array}{c}0.067^{* * *} \\
(0.012)\end{array}$ & $\begin{array}{c}0.040^{* * *} \\
(0.010)\end{array}$ \\
\hline Advanced * Year 30 & $\begin{array}{c}0.237^{* * *} \\
(0.049)\end{array}$ & $\begin{array}{c}0.255^{* * *} \\
(0.048)\end{array}$ & $\begin{array}{c}-0.133^{* * *} \\
(0.033)\end{array}$ & $\begin{array}{c}0.298^{* * *} \\
(0.051)\end{array}$ & $\begin{array}{c}0.367^{* * * *} \\
(0.053)\end{array}$ \\
\hline Advanced * Year 40 & $\begin{array}{c}0.229^{* * *} \\
(0.044)\end{array}$ & $\begin{array}{c}0.223^{* * *} \\
(0.045)\end{array}$ & $\begin{array}{c}-0.184^{* * *} \\
(0.053)\end{array}$ & $\begin{array}{c}0.375^{* * *} \\
(0.065)\end{array}$ & $\begin{array}{c}0.413^{* * *} \\
(0.068)\end{array}$ \\
\hline Plant FE & Yes & Yes & Yes & Yes & Yes \\
\hline Year FE & Yes & Yes & Yes & Yes & Yes \\
\hline Observations & 12,160 & 12,160 & 12,160 & 12,160 & 12,160 \\
\hline
\end{tabular}

Notes. Selected annual $\beta_{t}$ coefficients and $\gamma_{t}$ coefficients from Equation 1. Data are provided at the plant level from Steel Association Reports from 1949 to 2000. Prob. Oxy and Prob. Cast. are indicators for plants using the basic oxygen converters and the continuous casting furnaces. Log Import Capital, Exports and Int. St. are logged values of foreign imported capital, firm exports, and quantity of steel that meet international standards. Standard errors are clustered at the plant level. ${ }^{* * *} \mathrm{p}<0.01,{ }^{* *} \mathrm{p}<0.05,{ }^{*} \mathrm{p}<$ 0.1 . 
Table 4: Effects of the Soviet Technology Transfer on Steel Plant Human Capital

\begin{tabular}{|c|c|c|c|}
\hline & $\begin{array}{l}\text { Log Engineers } \\
\text { (1) }\end{array}$ & $\begin{array}{l}\text { Log High-Skilled } \\
\text { (2) }\end{array}$ & $\begin{array}{c}\text { Log Unskilled } \\
\text { (3) }\end{array}$ \\
\hline \multirow[t]{2}{*}{ Basic * Year 5} & 0.005 & -0.003 & -0.002 \\
\hline & $(0.007)$ & $(0.005)$ & $(0.004)$ \\
\hline \multirow[t]{2}{*}{ Basic * Year 10} & 0.006 & 0.003 & -0.009 \\
\hline & $(0.008)$ & $(0.005)$ & $(0.014)$ \\
\hline \multirow{2}{*}{ Basic * Year 20} & 0.012 & 0.015 & -0.022 \\
\hline & $(0.018)$ & $(0.020)$ & $(0.024)$ \\
\hline \multirow{2}{*}{ Basic * Year 30} & 0.014 & 0.011 & -0.026 \\
\hline & $(0.015)$ & $(0.010)$ & $(0.027)$ \\
\hline \multirow[t]{2}{*}{ Basic * Year 40} & 0.009 & 0.005 & -0.013 \\
\hline & $(0.010)$ & $(0.008)$ & $(0.016)$ \\
\hline \multirow{2}{*}{ Advanced*Year 1} & 0.004 & 0.005 & -0.010 \\
\hline & $(0.011)$ & $(0.012)$ & $(0.014)$ \\
\hline \multirow[t]{2}{*}{ Advanced*Year 5} & 0.003 & -0.005 & 0.002 \\
\hline & $(0.007)$ & $(0.005)$ & $(0.004)$ \\
\hline \multirow[t]{2}{*}{ Advanced*Year 10} & $0.026^{* * *}$ & $0.028^{* * *}$ & $-0.045^{* * *}$ \\
\hline & $(0.007)$ & $(0.005)$ & $(0.004)$ \\
\hline \multirow[t]{2}{*}{ Advanced*Year 20} & $0.043^{* * *}$ & $0.038^{* * *}$ & $-0.080^{* * *}$ \\
\hline & $(0.007)$ & $(0.005)$ & $(0.004)$ \\
\hline \multirow[t]{2}{*}{ Advanced*Year 30} & $0.063^{* * *}$ & $0.045^{* * *}$ & $-0.101^{* * *}$ \\
\hline & $(0.007)$ & $(0.007)$ & $(0.004)$ \\
\hline \multirow[t]{2}{*}{ Advanced * Year 40} & $0.085^{* * *}$ & $0.058 * * *$ & $-0.133^{* * *}$ \\
\hline & $(0.007)$ & $(0.007)$ & $(0.009)$ \\
\hline Plant FE & Yes & Yes & Yes \\
\hline Year FE & Yes & Yes & Yes \\
\hline Observations & 12,160 & 12,160 & 12,160 \\
\hline
\end{tabular}

Notes. Selected annual $\beta_{t}$ and $\gamma_{t}$ coefficients estimated from Equation 1. Data are provided at the plant level from Steel Association Reports from 1949 to 2000. Log Engineers, High-Skilled, and Unskilled are logged thousands of engineers, high-skilled technicians, and unskilled employees. Standard errors are clustered at the plant-level. ${ }^{* * *} \mathrm{p}<0.01,{ }^{* *} \mathrm{p}<0.05,{ }^{*} \mathrm{p}<0.1$. 
Table 5: Spillovers across Plants within Firm in the Steel Industry

\begin{tabular}{lcccccc}
\hline \hline & Log Output & Log TFPQ & Prob. Oxy. & Prob. Cast. & Log Exports & Log Int. St. \\
& $(1)$ & $(2)$ & $(3)$ & $(4)$ & $(5)$ & $(6)$ \\
\cline { 2 - 7 } Basic & 0.012 & 0.009 & -0.004 & 0.005 & -0.004 & 0.005 \\
& $(0.011)$ & $(0.013)$ & $(0.009)$ & $(0.008)$ & $(0.009)$ & $(0.008)$ \\
Advanced & 0.007 & 0.012 & 0.008 & 0.006 & 0.007 & 0.013 \\
& $(0.015)$ & $(0.016)$ & $(0.010)$ & $(0.009)$ & $(0.006)$ & $(0.018)$ \\
Basic * Post & 0.031 & 0.027 & -0.003 & 0.008 & 0.008 & 0.010 \\
& $(0.041)$ & $(0.029)$ & $(0.011)$ & $(0.015)$ & $(0.008)$ & $(0.013)$ \\
Advanced * Post & $0.223^{* * *}$ & $0.199^{* * *}$ & $0.425^{* * *}$ & $0.532^{* * *}$ & 0.002 & 0.005 \\
& $(0.049)$ & $(0.035)$ & $(0.078)$ & $(0.061)$ & $(0.009)$ & $(0.007)$ \\
Basic * Post 1978 & 0.007 & 0.004 & -0.005 & -0.005 & 0.009 & 0.012 \\
& $(0.009)$ & $(0.005)$ & $(0.008)$ & $(0.008)$ & $(0.013)$ & $(0.011)$ \\
Advanced * Post 1978 & $0.123^{* * *}$ & $0.198^{* * *}$ & $0.225^{* * *}$ & $0.233^{* * *}$ & $0.203^{* * *}$ & $0.258^{* * *}$ \\
& $(0.039)$ & $(0.041)$ & $(0.055)$ & $(0.042)$ & $(0.047)$ & $(0.062)$ \\
\hline Plant FE & Yes & Yes & Yes & Yes & Yes & Yes \\
Year FE & Yes & Yes & Yes & Yes & Yes & Yes \\
Observations & 12,346 & 12,346 & 12,346 & 12,346 & 12,346 & 12,346 \\
\hline \hline
\end{tabular}

Notes. Basic is an indicator for plants in firms that received a basic transfer. Advanced is an indicator for plants in firms that received an advanced transfer on top of an advanced transfer. Post is an indicator for years after receiving the Soviet transfer. Post1978 is an indicator for years after 1978. Log Output is logged quantities (in million tons) of steel. $\log T F P Q$ is logged total factor productivity quantity, computed as $\log T F P Q=\log T F P R-\tilde{p}$, where $\widetilde{p}$ is the revenue share weighted average of the prices of plant products and TFPR is calculated using the Gandhi et al. (2020)'s method. Prob. Oxy and Prob. Cast. are indicators for plants using the basic oxygen converters and the continuous casting furnaces. Log Import Capital, Exports and Int. St. are logged values of foreign imported capital, firm exports and quantity of steel that meet international standards. Data are provided at the plant level from the Steel Association Reports between 1949 and 2000. Standard errors are clustered at the plant level. ${ }^{* * *} \mathrm{p}<0.01,{ }^{* *} \mathrm{p}<0.05,{ }^{*} \mathrm{p}<0.1$. 
Table 6: Horizontal Spillovers in the Steel Industry

\begin{tabular}{lcccccc}
\hline \hline & Log Output & Log TFPQ & Prob. Oxy. & Prob. Cast. & Log Exports & Log Int. St. \\
& $(1)$ & $(2)$ & $(3)$ & $(4)$ & $(5)$ & $(6)$ \\
\cline { 2 - 7 } Basic & -0.018 & -0.016 & -0.009 & 0.007 & 0.008 & 0.009 \\
& $(0.022)$ & $(0.038)$ & $(0.010)$ & $(0.011)$ & $(0.010)$ & $(0.012)$ \\
Advanced & 0.012 & 0.014 & 0.006 & 0.011 & 0.005 & 0.006 \\
& $(0.014)$ & $(0.016)$ & $(0.008)$ & $(0.015)$ & $(0.007)$ & $(0.009)$ \\
Basic * Post & 0.006 & 0.011 & 0.009 & 0.012 & 0.007 & 0.012 \\
& $(0.008)$ & $(0.015)$ & $(0.010)$ & $(0.013)$ & $(0.011)$ & $(0.013)$ \\
Advanced * Post & $0.122^{* * *}$ & $0.117^{* * *}$ & $0.308^{* * *}$ & $0.319^{* * *}$ & 0.016 & 0.019 \\
& $(0.017)$ & $(0.015)$ & $(0.111)$ & $(0.123)$ & $0.011)$ & $(0.016)$ \\
Basic * Post 1978 & -0.015 & 0.022 & 0.004 & 0.006 & 0.005 & 0.009 \\
& $(0.020)$ & $(0.021)$ & $(0.010)$ & $(0.011)$ & $(0.008)$ & $(0.012)$ \\
Advanced * Post 1978 & $0.022^{* * *}$ & $0.018^{* * *}$ & $0.033^{* * *}$ & $0.045^{* * *}$ & $0.187^{* * *}$ & $0.201^{* * *}$ \\
& $(0.007)$ & $(0.006)$ & $(0.012)$ & $(0.009)$ & $(0.051)$ & $(0.065)$ \\
\hline Plant FE & Yes & Yes & Yes & Yes & Yes & Yes \\
Year FE & Yes & Yes & Yes & Yes & Yes & Yes \\
Observations & 13,550 & 13,550 & 13,550 & 13,550 & 13,550 & 13,550 \\
\hline \hline
\end{tabular}

Notes. Basic is an indicator for steel plants in the same counties of steel plants that received a basic transfer. Advanced is an indicator for steel plants in the same counties of steel plants that received an advanced transfer on top of a basic transfer. Post is an indicator for years after receiving the Soviet transfer. Post1978 is an indicator for years after 1978. Log Output is logged quantities (in million tons) of steel. $\log T F P Q$ is logged total factor productivity quantity, computed as $\log T F P Q=\log T F P R-\tilde{p}$, where $\widetilde{p}$ is the revenue share weighted average of the prices of plant products and TFPR is calculated using the Gandhi et al. (2020)'s method. Prob. Oxy and Prob. Cast. are indicators for plants using the basic oxygen converters and the continuous casting furnaces. Log Import Capital, Exports and Int. St. are logged values of foreign imported capital, firm exports and quantity of steel that meet international standards. Data are provided at the plant level from the Steel Association Reports between 1949 and 2000. Standard errors are clustered at the plant level. ${ }^{* * *} \mathrm{p}<0.01,{ }^{* *} \mathrm{p}<0.05,{ }^{*} \mathrm{p}<0.1$.

Table 7: Vertical Spillover Effects in the Steel Industry

\begin{tabular}{lcccccc}
\hline \hline & Log Output & Log TFPQ & Prob. Oxy. & Prob. Cast. & Log Exports & Log Int. St. \\
& $(1)$ & $(2)$ & $(3)$ & $(4)$ & $(5)$ & $(6)$ \\
\cline { 2 - 7 } Basic & 0.008 & 0.004 & 0.005 & 0.006 & 0.004 & 0.007 \\
& $(0.011)$ & $(0.006)$ & $(0.007)$ & $(0.010)$ & $(0.009)$ & $(0.010)$ \\
Advanced & 0.003 & 0.009 & 0.004 & 0.009 & 0.005 & 0.006 \\
& $(0.004)$ & $(0.006)$ & $(0.005)$ & $(0.010)$ & $(0.008)$ & $(0.009)$ \\
Basic * Post & $0.133^{* * *}$ & 0.011 & 0.009 & 0.006 & 0.016 & 0.012 \\
& $(0.022)$ & $(0.014)$ & $(0.011)$ & $(0.009)$ & $(0.015)$ & $(0.016)$ \\
Advanced * Post & $0.152^{* * *}$ & $0.132^{* * *}$ & $0.106^{* * *}$ & $0.100^{* * *}$ & 0.004 & 0.006 \\
& $(0.035)$ & $(0.039)$ & $(0.031)$ & $(0.025)$ & $(0.005)$ & $(0.009)$ \\
Basic * Post 1978 & -0.015 & 0.022 & 0.004 & 0.006 & 0.009 & 0.011 \\
& $(0.020)$ & $(0.021)$ & $(0.010)$ & $(0.011)$ & $(0.010)$ & $(0.025)$ \\
Advanced * Post 1978 & $0.034^{* * *}$ & $0.028^{* * *}$ & $0.029^{* * *}$ & $0.037^{* * *}$ & $0.145^{* * *}$ & $0.138^{* * *}$ \\
& $(0.008)$ & $(0.007)$ & $(0.008)$ & $(0.006)$ & $(0.032)$ & $(0.031)$ \\
\hline County-Year FE & Yes & Yes & Yes & Yes & Yes & Yes \\
Observations & 15,340 & 15,340 & 15,340 & 15,340 & 15,340 & 15,340 \\
\hline \hline
\end{tabular}

Notes. Basic is an indicator for steel plants in the same counties of nonsteel plants that received a basic transfer. Advanced is an indicator for steel plants in the same counties of nonsteel plants that received an advanced transfer on top of an advanced transfer. Post is an indicator for years after receiving the Soviet transfer. Post1978 is an indicator for years after 1978. Log Output is logged quantities (in million tons) of steel. $\log T F P Q$ is logged total factor productivity quantity, computed as $\log T F P Q=\log T F P R-\tilde{p}$, where $\tilde{p}$ is the revenue share weighted average of the prices of plant products and TFPR is calculated using the Gandhi et al. (2020)'s method. Prob. Oxy and Prob. Cast. are indicators for plants using the basic oxygen converters and the continuous casting furnacß $\mathrm{Log}$ Import Capital, Exports and Int. St. are logged values of foreign imported capital, firm exports and quantity of steel that meet international standards. Data are provided at the plant level from the Steel Association Reports between 1949 and 2000. Standard errors are clustered at the plant level. ${ }^{* * *} \mathrm{p}<0.01,{ }^{*} \mathrm{p}<0.05,{ }^{*} \mathrm{p}<0.1$. 
Table 8: Spillover Effects, 1998-2013

\begin{tabular}{|c|c|c|c|c|c|c|}
\hline & \multicolumn{2}{|c|}{ Log Value Added } & \multicolumn{2}{|c|}{ Log TFPR } & \multicolumn{2}{|c|}{ Log Exports } \\
\hline & $(1)$ & $(2)$ & $(3)$ & (4) & $(5)$ & $(6)$ \\
\hline \multicolumn{7}{|l|}{ Panel A: Related Firms } \\
\hline \multirow[t]{2}{*}{ Basic } & 0.013 & 0.010 & -0.005 & -0.003 & -0.012 & -0.010 \\
\hline & $(0.025)$ & $(0.020)$ & $(0.018)$ & $(0.009)$ & $(0.015)$ & $(0.012)$ \\
\hline \multirow[t]{2}{*}{ Advanced } & 0.011 & -0.009 & 0.003 & 0.004 & 0.008 & -0.015 \\
\hline & $(0.020)$ & $(0.012)$ & $(0.008)$ & $(0.004)$ & $(0.007)$ & $(0.018)$ \\
\hline \multirow[t]{2}{*}{ Basic $*$ Private } & 0.022 & 0.020 & 0.025 & 0.021 & 0.008 & 0.004 \\
\hline & $(0.031)$ & $(0.029)$ & $(0.028)$ & $(0.0283)$ & $(0.013)$ & $(0.003)$ \\
\hline \multirow[t]{2}{*}{ Advanced $*$ Private } & $0.215^{* * *}$ & $0.206^{* * *}$ & $0.209^{* * *}$ & $0.200^{* * *}$ & $0.134^{* * *}$ & $0.124^{* * *}$ \\
\hline & $(0.031)$ & $(0.044)$ & $(0.045)$ & $(0.041)$ & $(0.033)$ & $(0.028)$ \\
\hline \multirow[t]{2}{*}{ Basic $^{*}$ Private $*$ New } & 0.015 & 0.011 & 0.019 & 0.021 & 0.023 & 0.016 \\
\hline & $(0.018)$ & $(0.017)$ & $(0.026)$ & $(0.024)$ & $(0.022)$ & $(0.021)$ \\
\hline \multirow[t]{2}{*}{ Advanced $*$ Private $*$ New } & $0.033^{* * *}$ & $0.030^{* * *}$ & $0.031^{* * *}$ & $0.025^{* * *}$ & $0.050^{* * *}$ & $0.044^{* * *}$ \\
\hline & $(0.011)$ & $(0.009)$ & $(0.006)$ & $(0.005)$ & $(0.012)$ & $(0.010)$ \\
\hline Sector-Province-Year FE & Yes & No & Yes & No & Yes & No \\
\hline Sector-Prefecture-Year FE & No & Yes & No & Yes & No & Yes \\
\hline Observations & 160,123 & 160,123 & 160,123 & 160,123 & 160,123 & 160,123 \\
\hline \multicolumn{7}{|l|}{ Panel B: Not Related Firms } \\
\hline \multirow[t]{2}{*}{ Basic } & 0.012 & -0.004 & -0.003 & -0.015 & -0.005 & -0.004 \\
\hline & $(0.015)$ & $(0.011)$ & $(0.018)$ & $(0.016)$ & $(0.012)$ & $(0.009)$ \\
\hline \multirow[t]{2}{*}{ Advanced } & 0.004 & -0.003 & 0.004 & 0.003 & 0.003 & -0.002 \\
\hline & $(0.006)$ & $(0.006)$ & $(0.008)$ & $(0.007)$ & $(0.005)$ & $(0.004)$ \\
\hline \multirow[t]{2}{*}{ Basic * Private } & 0.005 & -0.004 & -0.004 & 0.008 & -0.005 & -0.003 \\
\hline & $(0.005)$ & $(0.012)$ & $(0.007)$ & $(0.011)$ & $(0.008)$ & $(0.005)$ \\
\hline \multirow[t]{2}{*}{ Advanced $*$ Private } & 0.002 & 0.005 & 0.003 & -0.004 & 0.001 & 0.007 \\
\hline & $(0.006)$ & $(0.010)$ & $(0.004)$ & $(0.005)$ & $(0.002)$ & $(0.008)$ \\
\hline \multirow[t]{2}{*}{ Basic $*$ Private $*$ New } & 0.002 & 0.005 & -0.002 & -0.003 & 0.003 & 0.001 \\
\hline & $(0.006)$ & $(0.008)$ & $(0.005)$ & $(0.009)$ & $(0.005)$ & $(0.003)$ \\
\hline \multirow[t]{2}{*}{ Advanced $*$ Private $*$ New } & -0.008 & -0.003 & 0.005 & -0.006 & 0.006 & 0.003 \\
\hline & $(0.010)$ & $(0.004)$ & $(0.005)$ & $(0.009)$ & $(0.009)$ & $(0.038)$ \\
\hline Sector-Province-Year FE & Yes & No & Yes & No & Yes & No \\
\hline Sector-Prefecture-Year FE & No & Yes & No & Yes & No & Yes \\
\hline Observations & 124,762 & 124,762 & 124,762 & 124,762 & 124,762 & 124,762 \\
\hline
\end{tabular}

Notes. Basic in an indicator for counties where plants that received a basic transfer were located. Advanced in an indicator for counties where plants that received an advanced transfer were located. Private is an indicator equal to one for non-state-owned firms. New is an indicator equal to one for firms that entered the market between 1998 and 2013. Log Value Added and Exports are measured in 2020 US\$ millions, reevaluated at 1 RMB in 1955=3.9605 USD in 2020; Log TFPR is logged total factor productivity revenue computed with Gandhi et al. (2020) method. Data are provided at the firm level from the China Industrial Enterprises database between 1998 and 2013. Standard errors are clustered at the firm level. ${ }^{* * *} \mathrm{p}<0.01$, ${ }^{* *} \mathrm{p}<0.05,{ }^{*} \mathrm{p}<0.1$. 


\section{Online Appendix — Not for Publication}

\section{Additional Figures and Tables}

Figure A.1: The 156 Projects by Industry

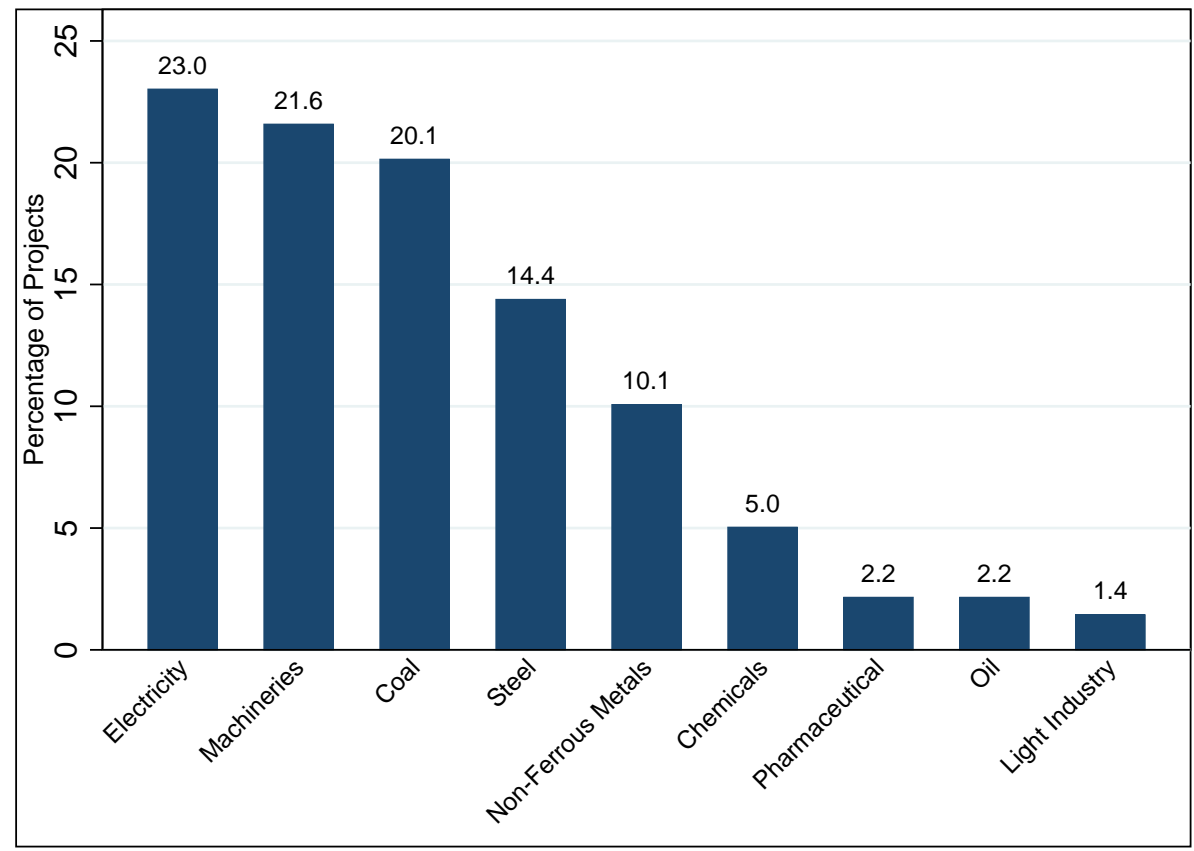

Notes. Distribution of the 139 approved technology transfer projects by industry, although 156 projects were initially contemplated. Data are provided at the project level from the National Archives Administration of China. 
Figure A.2: Industry Dynamics

Panel A: By Sector

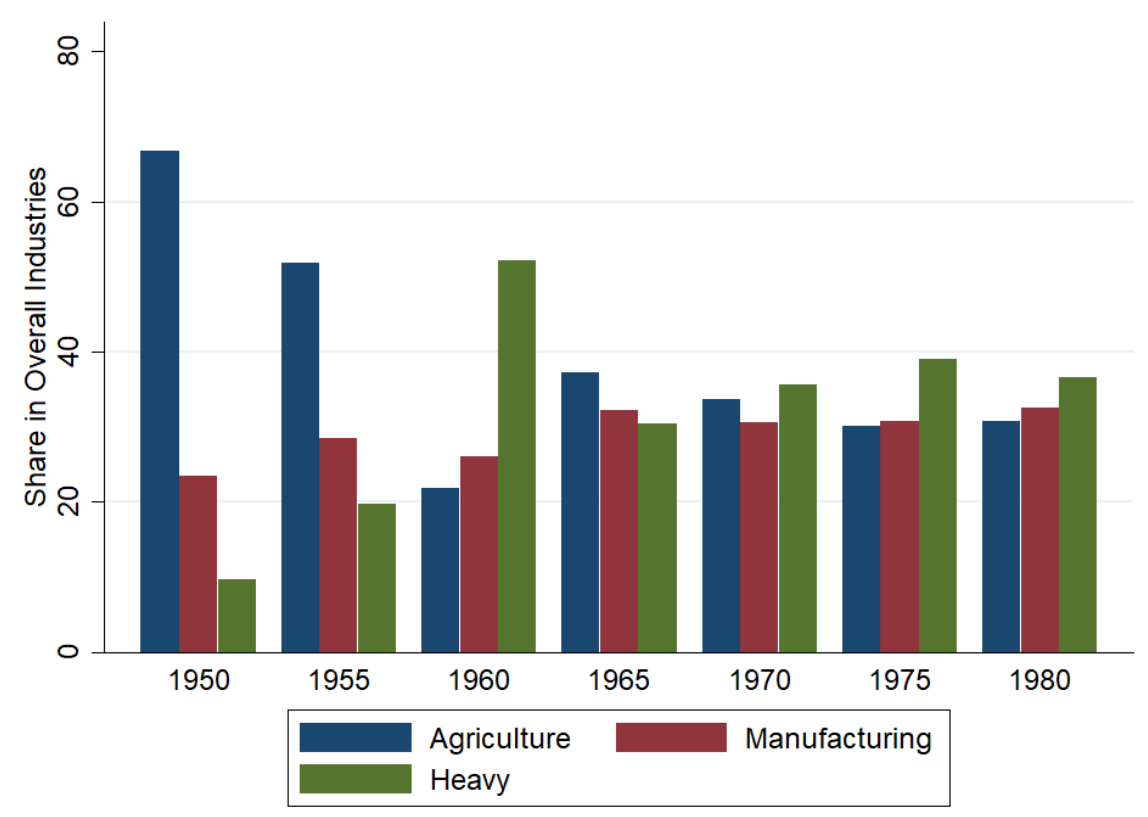

Panel B: By Industry

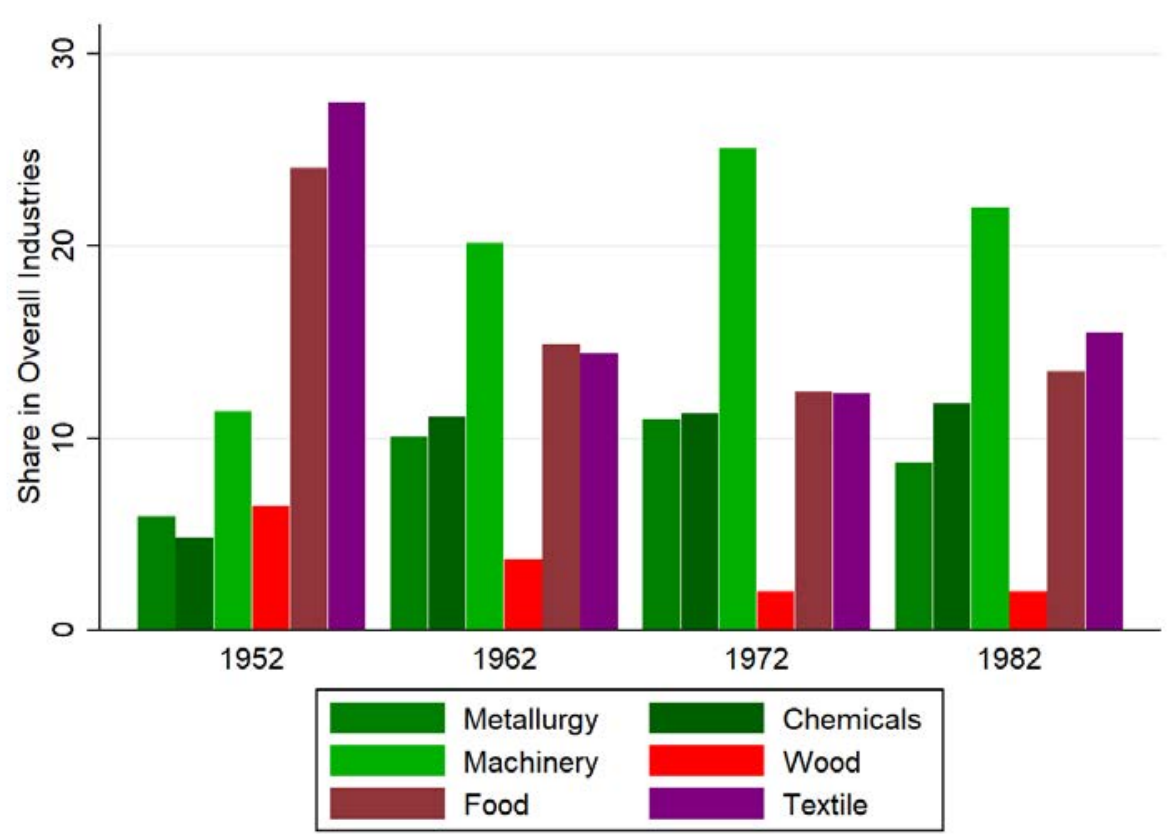

Notes. Panel A shows the percentage of firms in the agriculture, manufacturing, and heavy industries, respectively, from 1949 to 1985 . Panel B shows the detailed industry distribution in heavy industries (metallurgy, chemicals, and machinery), and manufacturing-related industries (wood, textile, food). Data are provided at the province level from the Statistical Yearbooks between 1949 and 1985. 
Figure A.3: Ownership and Regional Allocation

Panel A: Ownership Allocation

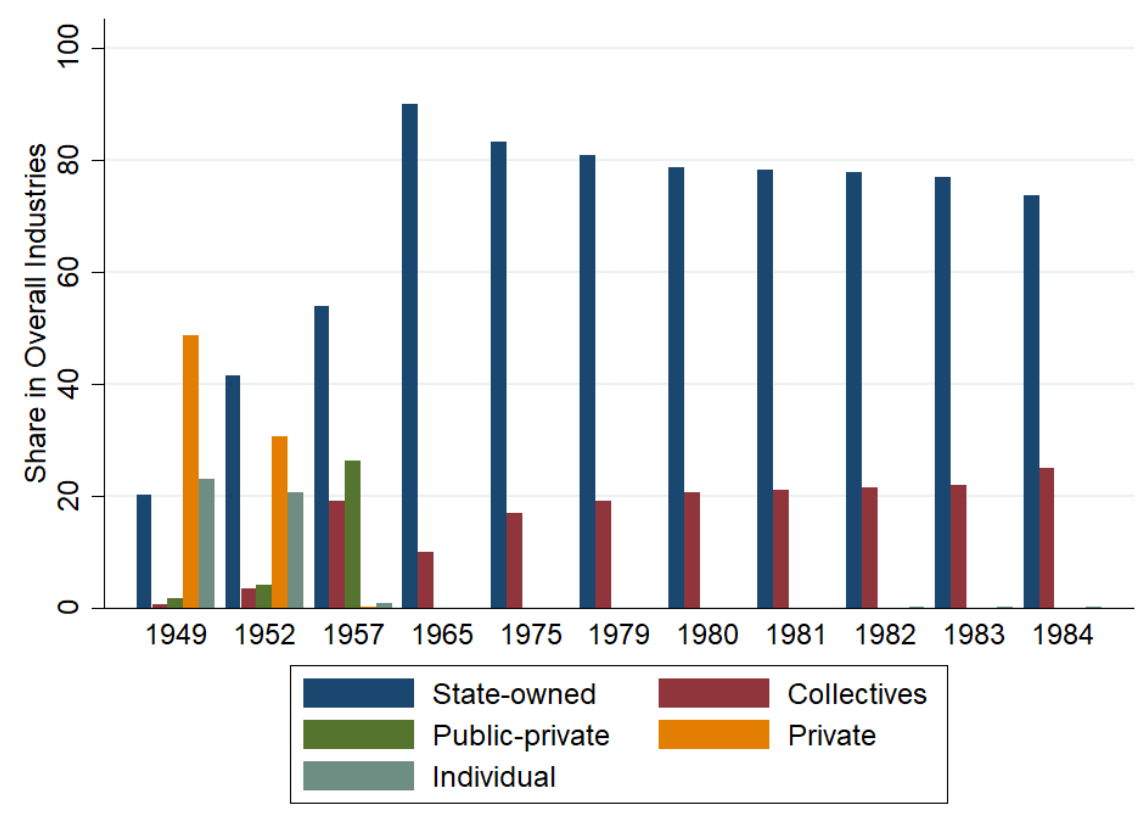

Panel B: Regional Allocation

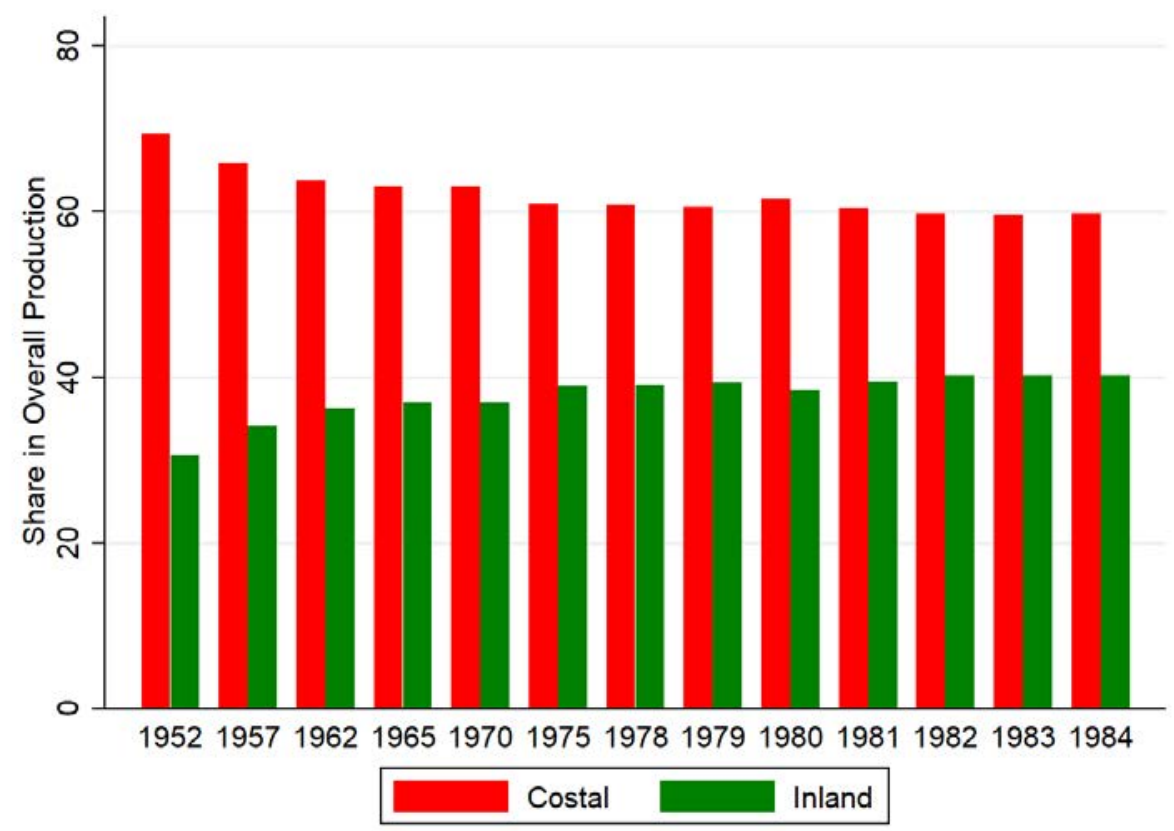

Notes. Panel A shows changes in the percentage of firms operating as state-owned, collective, public-private, private, and individual firms, respectively, from 1949 to 1985. Panel B displays the production allocation between coastal regions and inland regions. Data are provided at the province level from the Statistical Yearbooks between 1949 and 1985. 
Figure A.4: Probability of Receiving the Soviet Technology Transfer, by Prefectures and Counties

Panel A: Prefectures

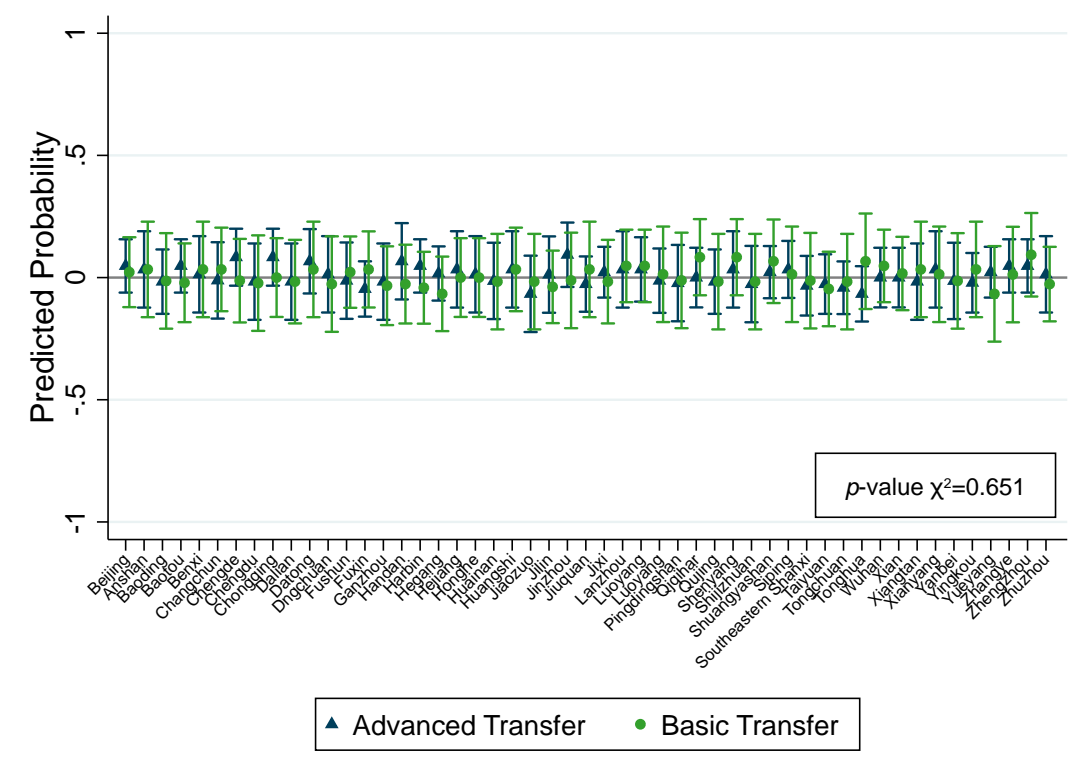

Panel B: Counties

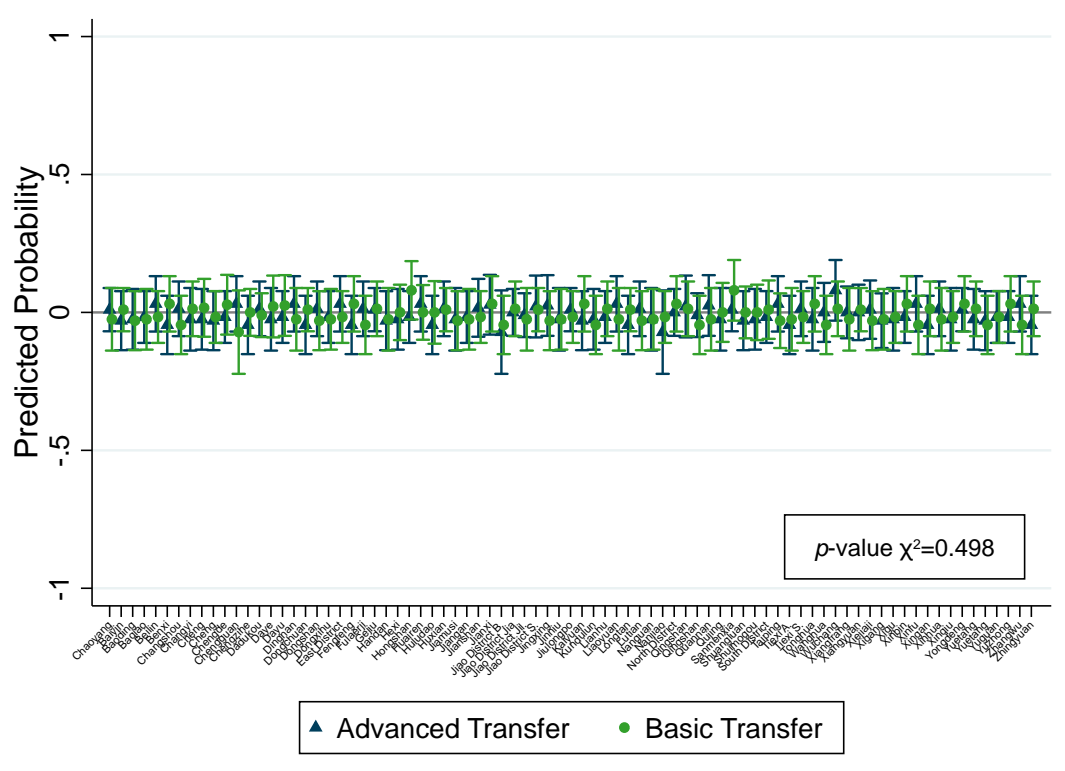

Notes. Predicted probabilities (marginal effects) of receiving a basic or an advanced transfer relative to the baseline of not receiving any Soviet transfer and $95 \%$ confidence intervals, estimated from the multinominal $\operatorname{logit} \log \left(\frac{\operatorname{Pr}\left(\operatorname{Transfer}_{i}=j\right)}{\operatorname{Pr}\left(\operatorname{Comparison}_{i}\right)}\right)=\alpha+\omega_{p}+\epsilon_{i}$ in Panel A and from the multinominal logit $\log \left(\frac{\operatorname{Pr}\left(\operatorname{Transfer}_{i}=j\right)}{\operatorname{Pr}\left(\operatorname{Comparison}_{i}\right)}\right)=$ $\alpha+\lambda_{c}+\nu_{i}$ in Panel B, where $\omega_{p}$ are project prefecture city fixed effects and $\lambda_{c}$ are project county fixed effects. $p$-values of $\chi^{2}$ test of joint equality of all coefficients to zero are reported in each panel. Data are provided at the project level from the National Archives Administration of China. 
Table A.1: Pre-Technology Transfer Differences in Counties Hosting Basic, Advanced and Comparison Plants in 1953

\begin{tabular}{lcccc}
\hline \hline & Log Total Firms & Log Population & Employment Share & Log Gvt. Funds \\
& $(1)$ & $(2)$ & $(3)$ & $(4)$ \\
\hline Basic & 0.018 & -0.013 & 0.006 & 0.003 \\
\multirow{3}{*}{ Advanced } & $(0.013)$ & $(0.011)$ & $(0.014)$ & $(0.006)$ \\
& -0.015 & 0.012 & 0.004 & 0.007 \\
& $(0.016)$ & $(0.013)$ & $(0.011)$ & $(0.012)$ \\
\hline Observations & 81 & 81 & 81 & 81 \\
\hline \hline
\end{tabular}

Notes. OLS regressions predicting county-level outcomes in 1953. Data are provided at county-level from the People's Republic of China Population Digest in 1953. Log total firms is logged total number of firms per county; Log population is logged total population of a county; Employment Share is the fraction of employed population over total population; Log Gvt. Funds is logged free transfers that the government granted to county, measured in 2020 US $\$$ millions, reevaluated at 1 RMB in $1955=3.9605$ USD in 2020. Basic is an indicator for counties where plants that received a basic transfer were located. Advanced is an indicator for counties where plants that received an advanced transfer were located. ${ }^{* * *} \mathrm{p}<0.01,{ }^{* *} \mathrm{p}<0.05,{ }^{*} \mathrm{p}<$ 0.1 . 
Table A.2: Pre-Soviet Technology Transfer Difference in Time Trends in Basic, Advanced and Comparison Steel Plants

\begin{tabular}{|c|c|c|c|c|c|c|c|c|}
\hline & \multicolumn{2}{|c|}{ Log Steel } & \multicolumn{2}{|c|}{ Log Crude Steel } & \multicolumn{2}{|c|}{ Log Pig Iron } & \multicolumn{2}{|c|}{ Log Current Assets } \\
\hline & $(1)$ & $(2)$ & $(3)$ & (4) & $(5)$ & $(6)$ & $(7)$ & $(8)$ \\
\hline \multirow[t]{2}{*}{ Basic $*$ Trend } & -0.001 & -0.002 & 0.006 & 0.007 & -0.004 & -0.007 & 0.002 & 0.002 \\
\hline & $(0.001)$ & $(0.003)$ & $(0.009)$ & $(0.008)$ & $(0.004)$ & $(0.009)$ & $(0.003)$ & $(0.004)$ \\
\hline \multirow[t]{2}{*}{ Advanced $*$ Trend } & 0.005 & 0.004 & 0.002 & -0.002 & -0.005 & -0.003 & -0.003 & -0.005 \\
\hline & $(0.008)$ & $(0.007)$ & $(0.003)$ & $(0.004)$ & $(0.007)$ & $(0.004)$ & $(0.004)$ & $(0.008)$ \\
\hline \multirow[t]{2}{*}{ Time Trend } & -0.009 & -0.003 & -0.002 & -0.003 & -0.004 & -0.005 & 0.009 & -0.003 \\
\hline & $(0.010)$ & $(0.004)$ & $(0.002)$ & $(0.006)$ & $(0.006)$ & $(0.008)$ & $(0.012)$ & $(0.006)$ \\
\hline \multirow[t]{2}{*}{ Basic } & 0.003 & 0.003 & -0.005 & -0.007 & 0.007 & 0.006 & -0.005 & -0.014 \\
\hline & $(0.006)$ & $(0.003)$ & $(0.009)$ & $(0.015)$ & $(0.015)$ & $(0.014)$ & $(0.011)$ & $(0.018)$ \\
\hline \multirow[t]{3}{*}{ Advanced } & 0.005 & -0.002 & -0.012 & -0.009 & -0.012 & -0.011 & -0.007 & -0.004 \\
\hline & $(0.005)$ & $(0.003)$ & $(0.010)$ & $(0.016)$ & $(0.016)$ & $(0.017)$ & $(0.014)$ & $(0.012)$ \\
\hline & \multicolumn{2}{|c|}{ Log Annual Sales } & \multicolumn{2}{|c|}{ Log Value Added } & \multicolumn{2}{|c|}{ Log TFPQ } & \multicolumn{2}{|c|}{ Log Employees } \\
\hline \multirow[t]{2}{*}{ Basic * Trend } & -0.002 & -0.003 & 0.002 & 0.005 & -0.002 & -0.003 & -0.006 & -0.004 \\
\hline & $(0.005)$ & $(0.004)$ & $(0.003)$ & $(0.010)$ & $(0.012)$ & $(0.009)$ & $(0.008)$ & $(0.006)$ \\
\hline \multirow[t]{2}{*}{ Advanced $*$ Trend } & 0.002 & 0.006 & 0.001 & 0.001 & -0.016 & -0.014 & 0.009 & 0.010 \\
\hline & $(0.005)$ & $(0.008)$ & $(0.002)$ & $(0.002)$ & $(0.017)$ & $(0.018)$ & $(0.010)$ & $(0.011)$ \\
\hline \multirow[t]{2}{*}{ Time Trend } & 0.002 & -0.001 & -0.002 & -0.002 & -0.004 & -0.002 & -0.002 & -0.003 \\
\hline & $(0.003)$ & $(0.002)$ & $(0.001)$ & $(0.004)$ & $(0.005)$ & $(0.003)$ & $(0.005)$ & $(0.006)$ \\
\hline \multirow[t]{2}{*}{ Basic } & -0.005 & 0.012 & -0.014 & -0.015 & -0.007 & -0.009 & 0.010 & 0.008 \\
\hline & $(0.017)$ & $(0.013)$ & $(0.012)$ & $(0.015)$ & $(0.006)$ & $(0.008)$ & $(0.011)$ & $(0.012)$ \\
\hline \multirow[t]{3}{*}{ Advanced } & -0.015 & -0.016 & 0.013 & 0.018 & -0.013 & 0.009 & 0.016 & 0.013 \\
\hline & $(0.016)$ & $(0.017)$ & $(0.017)$ & $(0.016)$ & $(0.016)$ & $(0.011)$ & $(0.014)$ & $(0.012)$ \\
\hline & \multicolumn{2}{|c|}{ Log Engineers } & \multicolumn{2}{|c|}{ Log High-Skilled } & \multicolumn{2}{|c|}{ Log Loans } & \multicolumn{2}{|c|}{ Log Transfers } \\
\hline \multirow[t]{2}{*}{ Basic $*$ Trend } & 0.002 & 0.005 & 0.007 & 0.007 & -0.004 & -0.003 & 0.013 & 0.013 \\
\hline & $(0.004)$ & $(0.008)$ & $(0.009)$ & $(0.014)$ & $(0.006)$ & $(0.004)$ & $(0.016)$ & $(0.016)$ \\
\hline \multirow[t]{2}{*}{ Advanced $*$ Trend } & -0.002 & -0.004 & 0.004 & 0.005 & -0.003 & -0.007 & 0.014 & 0.014 \\
\hline & $(0.004)$ & $(0.005)$ & $(0.003)$ & $(0.007)$ & $(0.011)$ & $(0.010)$ & $(0.011)$ & $(0.011)$ \\
\hline \multirow[t]{2}{*}{ Time Trend } & -0.005 & -0.006 & -0.003 & -0.002 & 0.001 & 0.002 & -0.013 & -0.015 \\
\hline & $(0.009)$ & $(0.008)$ & $(0.003)$ & $(0.002)$ & $(0.010)$ & $(0.009)$ & $(0.011)$ & $(0.010)$ \\
\hline \multirow[t]{2}{*}{ Basic } & -0.009 & -0.014 & -0.011 & -0.012 & 0.017 & 0.018 & 0.004 & -0.011 \\
\hline & $(0.014)$ & $(0.015)$ & $(0.015)$ & $(0.017)$ & $(0.018)$ & $(0.019)$ & $(0.005)$ & $(0.009)$ \\
\hline Advanced & 0.018 & 0.019 & -0.013 & -0.012 & 0.010 & 0.016 & 0.007 & 0.013 \\
\hline & $(0.013)$ & $(0.023)$ & $(0.011)$ & $(0.013)$ & $(0.012)$ & $(0.016)$ & $(0.012)$ & $(0.016)$ \\
\hline Observations & 2,114 & 2,114 & 2,114 & 2,114 & 2,114 & 2,114 & 2,114 & 2,114 \\
\hline Plant FE & Yes & No & Yes & No & Yes & No & Yes & No \\
\hline Plant x Year FE & No & Yes & No & Yes & No & Yes & No & Yes \\
\hline
\end{tabular}

Notes. OLS regressions predicting plant outcomes before receiving the Soviet transfer. Data are provided at plant level from the Steel Association Reports. Outcomes are allowed to vary according to a linear time trend that differs for plants that received a basic transfer (Soviet machinery and equipment) and for plants that received an advanced transfer (Soviet machinery and equipment and technical assistance). Steel, Crude Steel and Pig Iron Production are the in million tons. Current Assets, Annual Sales and Value Added are measured in 2020 US $\$$ millions, reevaluated at 1 RMB in 1955 $=3.9605$ USD in 2020; Productivity (logged $T F P Q$ ) is logged total factor productivity quantity, computed as $\log T F P Q=\log T F P R-\tilde{p}$, where $\widetilde{p}$ is the revenue-share weighted average of the prices of plant products, and TFPR is calculated using Gandhi et al. (2020)'s method; Employees per plant, Engineers, and High-Skilled Technicians are, respectively, thousands of employees, engineers, and high-skilled technicians; Loans and Transfers are, respectively, loans and free transfers that the government granted to each plant,A6easured in 2020 US $\$$ millions, reevaluated at 1 RMB in $1955=3.9605$ USD in 2020. Standard errors are clustered at the plant level. ${ }^{* * *} \mathrm{p}<0.01,{ }^{* *} \mathrm{p}<0.05,{ }^{*}$ $\mathrm{p}<0.1$. 
Table A.3: Pre-Soviet Technology Transfer Difference in Yearly Time Trends in Basic, Advanced and Comparison Steel Plants

\begin{tabular}{|c|c|c|c|c|c|c|c|c|}
\hline & \multicolumn{2}{|c|}{ Log Steel } & \multicolumn{2}{|c|}{ Log Crude Steel } & \multicolumn{2}{|c|}{ Log Pig Iron } & \multicolumn{2}{|c|}{ Log Current Assets } \\
\hline & $(1)$ & $(2)$ & $(3)$ & $(4)$ & $(5)$ & $(6)$ & $(7)$ & $(8)$ \\
\hline \multirow[t]{2}{*}{$\operatorname{Basic} *(\mathrm{t}-2)$} & 0.001 & -0.002 & -0.011 & -0.013 & 0.007 & -0.003 & -0.004 & 0.009 \\
\hline & $(0.006)$ & $(0.007)$ & $(0.014)$ & $(0.019)$ & $(0.012)$ & $(0.004)$ & $(0.012)$ & $(0.021)$ \\
\hline \multirow[t]{2}{*}{ Basic * (t-3) } & 0.012 & 0.008 & -0.012 & -0.010 & -0.008 & -0.017 & -0.008 & -0.006 \\
\hline & $(0.016)$ & $(0.007)$ & $(0.011)$ & $(0.020)$ & $(0.007)$ & $(0.014)$ & $(0.009)$ & $(0.008)$ \\
\hline \multirow[t]{2}{*}{$\operatorname{Basic}^{*}(\mathrm{t}-4)$} & 0.004 & -0.003 & -0.006 & -0.008 & 0.009 & 0.010 & -0.007 & -0.014 \\
\hline & $(0.007)$ & $(0.004)$ & $(0.007)$ & $(0.009)$ & $(0.012)$ & $(0.011)$ & $(0.007)$ & $(0.011)$ \\
\hline \multirow[t]{2}{*}{$\operatorname{Basic}^{*}(\mathrm{t}-5)$} & -0.002 & -0.006 & -0.016 & -0.012 & -0.013 & -0.014 & -0.008 & -0.010 \\
\hline & $(0.006)$ & $(0.007)$ & $(0.015)$ & $(0.011)$ & $(0.023)$ & $(0.022)$ & $(0.009)$ & $(0.011)$ \\
\hline \multirow[t]{2}{*}{ Advanced* (t-2) } & 0.006 & 0.003 & -0.004 & -0.007 & 0.002 & 0.003 & -0.012 & 0.015 \\
\hline & $(0.006)$ & $(0.007)$ & $(0.007)$ & $(0.009)$ & $(0.004)$ & $(0.003)$ & $(0.015)$ & $(0.018)$ \\
\hline \multirow[t]{2}{*}{ Advanced* (t-3) } & 0.005 & -0.004 & -0.009 & 0.007 & -0.008 & 0.005 & -0.009 & -0.007 \\
\hline & $(0.006)$ & $(0.007)$ & $(0.013)$ & $(0.009)$ & $(0.012)$ & $(0.011)$ & $(0.012)$ & $(0.018)$ \\
\hline \multirow[t]{2}{*}{ Advanced* (t-4) } & 0.008 & 0.005 & -0.011 & -0.014 & 0.008 & 0.011 & -0.005 & -0.006 \\
\hline & $(0.007)$ & $(0.007)$ & $(0.013)$ & $(0.015)$ & $(0.012)$ & $(0.012)$ & $(0.011)$ & $(0.010)$ \\
\hline \multirow[t]{2}{*}{ Advanced* (t-5) } & 0.004 & 0.002 & -0.009 & -0.013 & -0.006 & 0.007 & -0.006 & -0.009 \\
\hline & $(0.007)$ & $(0.004)$ & $(0.015)$ & $(0.012)$ & $(0.015)$ & $(0.014)$ & $(0.011)$ & $(0.010)$ \\
\hline Observations & 2,114 & 2,114 & 2,114 & 2,114 & 2,114 & 2,114 & 2,114 & 2,114 \\
\hline$F$-statistics & 0.486 & 0.368 & 0.435 & 0.482 & 0.251 & 0.308 & 0.699 & 0.372 \\
\hline
\end{tabular}

\begin{tabular}{|c|c|c|c|c|c|c|c|c|}
\hline \multirow[b]{2}{*}{$\operatorname{Basic}^{*}(\mathrm{t}-2)$} & \multicolumn{2}{|c|}{ Log Annual Sales } & \multicolumn{2}{|c|}{ Log Value Added } & \multicolumn{2}{|c|}{ Log TFPQ } & \multicolumn{2}{|c|}{ Log Employees } \\
\hline & $\begin{array}{c}-0.006 \\
(0.009)\end{array}$ & $\begin{array}{l}-0.007 \\
(0.008)\end{array}$ & $\begin{array}{l}-0.012 \\
(0.011)\end{array}$ & $\begin{array}{l}-0.017 \\
(0.019)\end{array}$ & $\begin{array}{l}-0.009 \\
(0.009)\end{array}$ & $\begin{array}{c}0.005 \\
(0.011)\end{array}$ & $\begin{array}{c}0.014 \\
(0.016)\end{array}$ & $\begin{array}{l}-0.011 \\
(0.015)\end{array}$ \\
\hline $\operatorname{Basic}^{*}(\mathrm{t}-3)$ & $\begin{array}{l}-0.012 \\
(0.015)\end{array}$ & $\begin{array}{c}0.016 \\
(0.014)\end{array}$ & $\begin{array}{c}0.012 \\
(0.010)\end{array}$ & $\begin{array}{l}-0.009 \\
(0.014)\end{array}$ & $\begin{array}{l}-0.008 \\
(0.007)\end{array}$ & $\begin{array}{l}-0.009 \\
(0.010)\end{array}$ & $\begin{array}{l}-0.007 \\
(0.011)\end{array}$ & $\begin{array}{l}-0.008 \\
(0.009)\end{array}$ \\
\hline $\operatorname{Basic} *(\mathrm{t}-4)$ & $\begin{array}{l}-0.007 \\
(0.011)\end{array}$ & $\begin{array}{l}-0.009 \\
(0.010)\end{array}$ & $\begin{array}{l}-0.012 \\
(0.013)\end{array}$ & $\begin{array}{c}-0.014 \\
(0.019)\end{array}$ & $\begin{array}{c}-0.004 \\
(0.005)\end{array}$ & $\begin{array}{c}0.005 \\
(0.006)\end{array}$ & $\begin{array}{c}0.012 \\
(0.016)\end{array}$ & $\begin{array}{l}-0.013 \\
(0.014)\end{array}$ \\
\hline $\operatorname{Basic}^{*}(\mathrm{t}-5)$ & $\begin{array}{l}-0.008 \\
(0.013)\end{array}$ & $\begin{array}{l}-0.009 \\
(0.014)\end{array}$ & $\begin{array}{c}0.021 \\
(0.029)\end{array}$ & $\begin{array}{c}0.022 \\
(0.033)\end{array}$ & $\begin{array}{c}0.017 \\
(0.015)\end{array}$ & $\begin{array}{c}0.014 \\
(0.011)\end{array}$ & $\begin{array}{c}0.013 \\
(0.014)\end{array}$ & $\begin{array}{c}0.012 \\
(0.010)\end{array}$ \\
\hline Advanced* (t-2) & $\begin{array}{c}0.003 \\
(0.004)\end{array}$ & $\begin{array}{c}0.004 \\
(0.008)\end{array}$ & $\begin{array}{l}-0.012 \\
(0.014)\end{array}$ & $\begin{array}{c}-0.014 \\
(0.019)\end{array}$ & $\begin{array}{c}-0.012 \\
(0.016)\end{array}$ & $\begin{array}{c}-0.013 \\
(0.013)\end{array}$ & $\begin{array}{c}0.006 \\
(0.006)\end{array}$ & $\begin{array}{c}0.009 \\
(0.014)\end{array}$ \\
\hline Advanced* (t-3) & $\begin{array}{c}0.005 \\
(0.008)\end{array}$ & $\begin{array}{c}0.008 \\
(0.012)\end{array}$ & $\begin{array}{c}0.007 \\
(0.010)\end{array}$ & $\begin{array}{c}-0.004 \\
(0.014)\end{array}$ & $\begin{array}{l}-0.006 \\
(0.009)\end{array}$ & $\begin{array}{l}-0.003 \\
(0.006)\end{array}$ & $\begin{array}{c}0.006 \\
(0.009)\end{array}$ & $\begin{array}{c}0.004 \\
(0.009)\end{array}$ \\
\hline Advanced* (t-4) & $\begin{array}{l}-0.008 \\
(0.009)\end{array}$ & $\begin{array}{l}-0.010 \\
(0.011)\end{array}$ & $\begin{array}{l}-0.008 \\
(0.013)\end{array}$ & $\begin{array}{l}-0.008 \\
(0.014)\end{array}$ & $\begin{array}{l}-0.005 \\
(0.009)\end{array}$ & $\begin{array}{c}0.012 \\
(0.011)\end{array}$ & $\begin{array}{c}0.004 \\
(0.008)\end{array}$ & $\begin{array}{c}0.005 \\
(0.009)\end{array}$ \\
\hline Advanced* (t-5) & $\begin{array}{c}0.010 \\
(0.015)\end{array}$ & $\begin{array}{c}0.008 \\
(0.014)\end{array}$ & $\begin{array}{c}0.006 \\
(0.009)\end{array}$ & $\begin{array}{l}-0.005 \\
(0.013)\end{array}$ & $\begin{array}{c}-0.007 \\
(0.007)\end{array}$ & $\begin{array}{c}-0.006 \\
(0.009)\end{array}$ & $\begin{array}{c}0.007 \\
(0.012)\end{array}$ & $\begin{array}{c}0.010 \\
(0.009)\end{array}$ \\
\hline Observations & 2,114 & 2,114 & 2,114 & 2,114 & 2,114 & 2,114 & 2,114 & 2,114 \\
\hline$F$-statistics & 0.563 & 0.484 & 0.427 & 0.623 & 0.361 & 0.645 & 0.623 & 0.337 \\
\hline
\end{tabular}


Table A.3: Continued

\begin{tabular}{|c|c|c|c|c|c|c|c|c|}
\hline \multirow[b]{2}{*}{$\operatorname{Basic}^{*}(\mathrm{t}-2)$} & \multicolumn{2}{|c|}{ Log Engineers } & \multicolumn{2}{|c|}{ Log High-Skilled } & \multicolumn{2}{|c|}{ Log Loans } & \multicolumn{2}{|c|}{ Log Transfers } \\
\hline & $\begin{array}{l}-0.009 \\
(0.013)\end{array}$ & $\begin{array}{c}0.015 \\
(0.030)\end{array}$ & $\begin{array}{l}-0.007 \\
(0.013)\end{array}$ & $\begin{array}{l}-0.013 \\
(0.012)\end{array}$ & $\begin{array}{l}-0.018 \\
(0.013)\end{array}$ & $\begin{array}{c}0.010 \\
(0.014)\end{array}$ & $\begin{array}{l}-0.007 \\
(0.006)\end{array}$ & $\begin{array}{l}-0.009 \\
(0.014)\end{array}$ \\
\hline $\operatorname{Basic}^{*}(\mathrm{t}-3)$ & $\begin{array}{c}0.013 \\
(0.019)\end{array}$ & $\begin{array}{c}0.022 \\
(0.027)\end{array}$ & $\begin{array}{l}-0.005 \\
(0.007)\end{array}$ & $\begin{array}{c}0.005 \\
(0.007)\end{array}$ & $\begin{array}{c}0.017 \\
(0.015)\end{array}$ & $\begin{array}{c}0.011 \\
(0.009)\end{array}$ & $\begin{array}{c}0.009 \\
(0.016)\end{array}$ & $\begin{array}{c}0.010 \\
(0.011)\end{array}$ \\
\hline $\operatorname{Basic} *(t-4)$ & $\begin{array}{l}-0.014 \\
(0.020)\end{array}$ & $\begin{array}{c}0.020 \\
(0.028)\end{array}$ & $\begin{array}{l}-0.011 \\
(0.012)\end{array}$ & $\begin{array}{l}-0.004 \\
(0.009)\end{array}$ & $\begin{array}{c}0.007 \\
(0.006)\end{array}$ & $\begin{array}{c}0.012 \\
(0.010)\end{array}$ & $\begin{array}{c}0.009 \\
(0.009)\end{array}$ & $\begin{array}{l}-0.011 \\
(0.009)\end{array}$ \\
\hline $\operatorname{Basic}^{*}(\mathrm{t}-5)$ & $\begin{array}{c}0.011 \\
(0.018)\end{array}$ & $\begin{array}{c}0.012 \\
(0.015)\end{array}$ & $\begin{array}{l}-0.009 \\
(0.011)\end{array}$ & $\begin{array}{l}-0.011 \\
(0.015)\end{array}$ & $\begin{array}{c}0.006 \\
(0.006)\end{array}$ & $\begin{array}{c}0.008 \\
(0.007)\end{array}$ & $\begin{array}{c}0.015 \\
(0.014)\end{array}$ & $\begin{array}{c}0.020 \\
(0.018)\end{array}$ \\
\hline Advanced* (t-2) & $\begin{array}{l}-0.016 \\
(0.019)\end{array}$ & $\begin{array}{c}0.018 \\
(0.018)\end{array}$ & $\begin{array}{l}-0.010 \\
(0.012)\end{array}$ & $\begin{array}{c}0.013 \\
(0.015)\end{array}$ & $\begin{array}{c}0.004 \\
(0.0607)\end{array}$ & $\begin{array}{c}0.009 \\
(0.010)\end{array}$ & $\begin{array}{c}0.008 \\
(0.010)\end{array}$ & $\begin{array}{c}0.006 \\
(0.007)\end{array}$ \\
\hline Advanced* (t-3) & $\begin{array}{c}0.015 \\
(0.020)\end{array}$ & $\begin{array}{c}0.014 \\
(0.017)\end{array}$ & $\begin{array}{l}-0.019 \\
(0.020)\end{array}$ & $\begin{array}{c}0.011 \\
(0.015)\end{array}$ & $\begin{array}{c}0.016 \\
(0.018)\end{array}$ & $\begin{array}{c}0.012 \\
(0.016)\end{array}$ & $\begin{array}{c}0.008 \\
(0.009)\end{array}$ & $\begin{array}{c}0.009 \\
(0.010)\end{array}$ \\
\hline Advanced* (t-4) & $\begin{array}{l}-0.014 \\
(0.020)\end{array}$ & $\begin{array}{l}-0.015 \\
(0.016)\end{array}$ & $\begin{array}{l}-0.003 \\
(0.005)\end{array}$ & $\begin{array}{l}-0.004 \\
(0.009)\end{array}$ & $\begin{array}{c}0.008 \\
(0.008)\end{array}$ & $\begin{array}{c}0.007 \\
(0.009)\end{array}$ & $\begin{array}{c}0.012 \\
(0.015)\end{array}$ & $\begin{array}{c}0.010 \\
(0.012)\end{array}$ \\
\hline Advanced* (t-5) & $\begin{array}{c}0.007 \\
(0.011)\end{array}$ & $\begin{array}{l}-0.004 \\
(0.006)\end{array}$ & $\begin{array}{l}-0.009 \\
(0.014)\end{array}$ & $\begin{array}{c}0.011 \\
(0.020)\end{array}$ & $\begin{array}{c}0.012 \\
(0.013)\end{array}$ & $\begin{array}{c}0.009 \\
(0.010)\end{array}$ & $\begin{array}{c}0.012 \\
(0.016)\end{array}$ & $\begin{array}{l}-0.013 \\
(0.010) \\
\end{array}$ \\
\hline Observations & 2,114 & 2,114 & 2,114 & 2,114 & 2,114 & 2,114 & 2,114 & 2,114 \\
\hline$F$-statistics & 0.709 & 0.295 & 0.337 & 0.438 & 0.380 & 0.659 & 0.410 & 0.413 \\
\hline
\end{tabular}

Notes. OLS regressions predicting plant outcomes before in the five years before receiving the Soviet transfer. Data are provided at plant level from the Steel Association Reports. The trend is allowed to vary freely for each year before receiving the Soviet transfer for plants that received a basic transfer (Soviet machinery and equipment) and for plants that received an advanced transfer (Soviet machinery and equipment and technical assistance). Time period indicators are included, but not reported. The omitted period is $\mathrm{t}=-1$, the year before receiving the Soviet transfer. Steel, Crude Steel and Pig Iron Production are the in million tons. Current Assets, Annual Sales and Value Added are measured in 2020 US\$ millions, reevaluated at 1 RMB in $1955=3.9605$ USD in 2020; Productivity (logged TFPQ) is logged total factor productivity quantity, computed as $\log T F P Q=\log T F P R-\tilde{p}$, where $\widetilde{p}$ is the revenue-share weighted average of the prices of plant products, and TFPR is calculated using Gandhi et al. (2020)'s method; Employees per plant, Engineers, and High-Skilled Technicians are, respectively, thousands of employees, engineers, and high-skilled technicians; Loans and Transfers are, respectively, loans and free transfers that the government granted to each plant, measured in 2020 US $\$$ millions, reevaluated at 1 RMB in $1955=3.9605$ USD in 2020. Standard errors are clustered at the plant level. ${ }^{* * *} \mathrm{p}<0.01,{ }^{* *} \mathrm{p}<0.05,{ }^{*} \mathrm{p}<0.1$. The $F$-statistics test whether all the interaction terms between basic and advanced plants and the year indicators are jointly zero. 
Table A.4: Effects of the Soviet Technology Transfer on Output Quality, Workers, and Inputs in Steel Plants

\begin{tabular}{lccccc}
\hline \hline & Log Crude Steel & Log Pig Iron & Log Workers & Log Coke & Log Iron \\
& $(1)$ & $(2)$ & $(3)$ & $(4)$ & $(5)$ \\
\cline { 2 - 6 } Basic * Year 1 & 0.011 & -0.018 & -0.009 & 0.005 & -0.008 \\
& $(0.011)$ & $(0.020)$ & $(0.008)$ & $(0.007)$ & $(0.012)$ \\
Basic * Year 5 & $0.099^{* *}$ & $-0.069^{* * *}$ & 0.005 & 0.004 & -0.002 \\
& $(0.051)$ & $(0.017)$ & $(0.006)$ & $(0.006)$ & $(0.005)$ \\
Basic * Year 10 & $0.159^{* * *}$ & $-0.123^{* * *}$ & -0.003 & 0.003 & 0.004 \\
& $(0.033)$ & $(0.035)$ & $(0.004)$ & $(0.007)$ & $(0.006)$ \\
Basic * Year 20 & 0.061 & -0.058 & -0.008 & 0.006 & -0.005 \\
& $(0.047)$ & $(0.049)$ & $(0.010)$ & $(0.005)$ & $(0.009)$ \\
Basic * Year 30 & 0.017 & -0.016 & 0.004 & 0.007 & 0.009 \\
& $(0.044)$ & $(0.019)$ & $(0.007)$ & $(0.007)$ & $(0.011)$ \\
Basic * Year 40 & 0.004 & -0.032 & 0.005 & -0.005 & 0.003 \\
Advanced * Year 1 & $(0.035)$ & $(0.030)$ & $(0.007)$ & $(0.006)$ & $(0.004)$ \\
Advanced * Year 5 & $0.055^{* * *}$ & $-0.048^{* * *}$ & -0.006 & -0.003 & -0.002 \\
Advanced * Year 10 & $(0.015)$ & $(0.012)$ & $(0.008)$ & $(0.005)$ & $(0.003)$ \\
& $0.178^{* * *}$ & $-0.138^{* * *}$ & 0.002 & -0.002 & -0.003 \\
Advanced * Year 20 & $(0.046)$ & $(0.044)$ & $(0.003)$ & $(0.004)$ & $(0.007)$ \\
& $0.209^{* * *}$ & $-0.189^{* * *}$ & -0.001 & 0.004 & -0.005 \\
Advanced * Year 30 & $(0.049)$ & $(0.048)$ & $(0.003)$ & $(0.006)$ & $(0.008)$ \\
Advanced * Year 40 & $0.223^{* * *}$ & $-0.202^{* * *}$ & -0.008 & -0.002 & 0.007 \\
& $(0.057)$ & $(0.055)$ & $(0.011)$ & $(0.011)$ & $(0.012)$ \\
\hline Plant FE & $0.258^{* * *}$ & $-0.217^{* * *}$ & 0.005 & 0.003 & -0.002 \\
Year FE & $(0.061)$ & $(0.057)$ & $(0.007)$ & $(0.004)$ & $(0.003)$ \\
Observations & $0.293^{* * *}$ & $-0.251^{* * *}$ & 0.008 & 0.006 & -0.004 \\
\hline \hline & $(0.070)$ & $(0.063)$ & $(0.010)$ & $(0.009)$ & $(0.005)$ \\
\hline
\end{tabular}

Notes. Selected annual $\beta_{t}$ and $\gamma_{t}$ coefficients estimated from Equation 1. Data are provided at the plant level from the Steel Association Reports from 1949 to 2000. Log Crude Steel, Pig Iron, Coke, Iron are logged quantities (in million tons) of crude steel, pig iron, coke, iron; Log Employees is logged thousands of employees per plant. Standard errors are clustered at the plant level. ${ }^{* * *} \mathrm{p}<0.01,{ }^{* *} \mathrm{p}<0.05,{ }^{*} \mathrm{p}<0.1$. 
Table A.5: Robustness Checks of Main Results to Alternative Fixed Effects

\begin{tabular}{|c|c|c|c|c|c|c|c|c|}
\hline & \multicolumn{4}{|c|}{ "Log Output (1-4) } & \multicolumn{4}{|c|}{ "Log TFPQ (5-8) } \\
\hline & (1) & (2) & (3) & $(4)$ & $(5)$ & (6) & (7) & $(8)$ \\
\hline \multirow[t]{2}{*}{ Basic * Year 1} & 0.002 & 0.003 & 0.004 & 0.006 & 0.001 & 0.003 & 0.004 & 0.006 \\
\hline & $(0.018)$ & $(0.019)$ & $(0.017)$ & $(0.016)$ & $(0.017)$ & $(0.019)$ & $(0.017)$ & $(0.016)$ \\
\hline \multirow[t]{2}{*}{ Basic * Year 5} & $0.113^{* * *}$ & $0.115^{* * *}$ & $0.118^{* * *}$ & $0.117^{* * *}$ & $0.106^{* * *}$ & $0.108^{* * *}$ & $0.111^{* * *}$ & $0.109^{* * *}$ \\
\hline & $(0.017)$ & $(0.020)$ & $(0.018)$ & $(0.025)$ & $(0.018)$ & $(0.020)$ & $(0.022)$ & $(0.019)$ \\
\hline \multirow[t]{2}{*}{ Basic * Year 10} & $0.130 * * *$ & $0.138^{* * *}$ & $0.141^{* * *}$ & $0.139^{* * *}$ & $0.128 * * *$ & $0.132^{* * *}$ & $0.137 * * *$ & $0.141^{* * *}$ \\
\hline & $(0.025)$ & $(0.022)$ & $(0.024)$ & $(0.024)$ & $(0.023)$ & $(0.026)$ & $(0.025)$ & $(0.027)$ \\
\hline \multirow[t]{2}{*}{ Basic * Year 20} & $0.085^{*}$ & $0.090^{*}$ & $0.088^{*}$ & $0.087^{*}$ & $0.081^{*}$ & $0.085^{*}$ & $0.088^{*}$ & $0.091^{*}$ \\
\hline & $(0.046)$ & $(0.050)$ & $(0.049)$ & $(0.051)$ & $(0.047)$ & $(0.048)$ & $(0.050)$ & $(0.049)$ \\
\hline \multirow[t]{2}{*}{ Basic * Year 30} & 0.039 & 0.041 & 0.040 & 0.042 & 0.035 & 0.039 & 0.041 & 0.044 \\
\hline & $(0.044)$ & $(0.045)$ & $(0.047)$ & $(0.041)$ & $(0.041)$ & $(0.042)$ & $(0.044)$ & $(0.040)$ \\
\hline \multirow[t]{2}{*}{ Basic * Year 40} & 0.009 & 0.008 & 0.010 & 0.011 & 0.001 & 0.002 & 0.005 & 0.006 \\
\hline & $(0.043)$ & $(0.041)$ & $(0.043)$ & $(0.046)$ & $(0.043)$ & $(0.045)$ & $(0.044)$ & $(0.041)$ \\
\hline \multirow[t]{2}{*}{ Advanced $*$ Year 1} & $0.062^{* * *}$ & $0.065^{* * *}$ & $0.067^{* * *}$ & $0.066^{* * *}$ & $0.061^{* * *}$ & $0.066^{* * *}$ & $0.069^{* * *}$ & $0.070^{* * *}$ \\
\hline & $(0.017)$ & $(0.015)$ & $(0.019)$ & $(0.021)$ & $(0.016)$ & $(0.018)$ & $(0.021)$ & $(0.020)$ \\
\hline \multirow[t]{2}{*}{ Advanced * Year 5} & $0.089 * * *$ & $0.093^{* * *}$ & $0.096^{* * *}$ & $0.098 * * *$ & $0.078^{* * *}$ & $0.080^{* * *}$ & $0.082^{* * *}$ & $0.085^{* * *}$ \\
\hline & $(0.018)$ & $(0.020)$ & $(0.022)$ & $(0.024)$ & $(0.018)$ & $(0.019)$ & $(0.020)$ & $(0.021)$ \\
\hline \multirow[t]{2}{*}{ Advanced * Year 10} & $0.098^{* * *}$ & $0.103^{* * *}$ & $0.107^{* * *}$ & $0.105^{* * *}$ & $0.093^{* * *}$ & $0.097^{* * *}$ & $0.101^{* * *}$ & $0.103^{* * *}$ \\
\hline & $(0.029)$ & $(0.032)$ & $(0.034)$ & $(0.031)$ & $(0.027)$ & $(0.030)$ & $(0.031)$ & $(0.029)$ \\
\hline \multirow[t]{2}{*}{ Advanced * Year 20} & $0.180^{* * *}$ & $0.184^{* * *}$ & $0.187^{* * *}$ & $0.183^{* * *}$ & $0.173^{* * *}$ & $0.175^{* * *}$ & $0.178^{* * *}$ & $0.181^{* * *}$ \\
\hline & $(0.030)$ & $(0.028)$ & $(0.031)$ & $(0.034)$ & $(0.029)$ & $(0.030)$ & $(0.032)$ & $(0.034)$ \\
\hline \multirow[t]{2}{*}{ Advanced * Year 30} & $0.292^{* * *}$ & $0.293^{* * *}$ & $0.297^{* * *}$ & $0.295^{* * *}$ & $0.281^{* * *}$ & $0.284^{* * *}$ & $0.287^{* * *}$ & $0.290^{* * *}$ \\
\hline & $(0.038)$ & $(0.036)$ & $(0.039)$ & $(0.041)$ & $(0.037)$ & $(0.039)$ & $(0.040)$ & $(0.042)$ \\
\hline \multirow[t]{2}{*}{ Advanced * Year 40} & $0.402^{* * *}$ & $0.409^{* * *}$ & $0.413^{* * *}$ & $0.411^{* * *}$ & $0.391 * * *$ & $0.394^{* * *}$ & $0.398^{* * *}$ & $0.400^{* * *}$ \\
\hline & $(0.040)$ & $(0.042)$ & $(0.041)$ & $(0.039)$ & $(0.035)$ & $(0.039)$ & $(0.041)$ & $(0.039)$ \\
\hline Plant FE & Yes & No & No & Yes & Yes & No & No & Yes \\
\hline Year FE & Yes & No & No & Yes & Yes & No & No & Yes \\
\hline Firm-Year FE & No & Yes & No & No & No & Yes & No & No \\
\hline County-Year FE & No & No & Yes & No & No & No & Yes & No \\
\hline Sun and Abraham (2021) & No & No & No & Yes & No & No & No & Yes \\
\hline Observations & 12,160 & 12,160 & 12,160 & 12,160 & 12,160 & 12,160 & 12,160 & 12,160 \\
\hline
\end{tabular}

Notes. Selected annual $\beta_{t}$ coefficients and $\gamma_{t}$ coefficients from Equation 1 in columns 1 and 6 , substituting plant and year fixed effects with firm-year fixed effects (columns 2 and 6) or county-year fixed effects (columns 3 and 7). In columns 4 and 8, we estimate weights underlying two-way fixed effects regressions based on Sun and Abraham (2021)'s method, using the Stata command eventstudyweights. Data are provided at the plant level from the Steel Association Reports from 1949 to 2000. Output is logged quantities (in million tons) of steel. TFPQ is logged total factor productivity quantity, computed as $\log T F P Q=\log T F P R-\tilde{p}$, where $\widetilde{p}$ is the revenue-share weighted average of the prices of plant products, and TFPR is calculated using Gandhi et al. (2020)'s method. Standard errors are clustered at the plant level. *** $\mathrm{p}<0.01,{ }^{* *} \mathrm{p}<0.05$, $* \mathrm{p}<0.1$. 
Table A.6: Robustness Checks of Main Results to Alternative Timing

\begin{tabular}{|c|c|c|c|c|c|c|}
\hline \multirow[b]{3}{*}{ Basic * Year 1} & \multicolumn{3}{|c|}{ Log Output (1-3) } & \multicolumn{3}{|c|}{ Log TFPQ (4-6) } \\
\hline & $(1)$ & $(2)$ & $(3)$ & $(4)$ & $(5)$ & $(6)$ \\
\hline & $\begin{array}{c}0.002 \\
(0.018)\end{array}$ & $\begin{array}{c}0.002 \\
(0.015)\end{array}$ & $\begin{array}{c}0.002 \\
(0.016)\end{array}$ & $\begin{array}{c}0.001 \\
(0.017)\end{array}$ & $\begin{array}{c}0.002 \\
(0.016)\end{array}$ & $\begin{array}{c}0.005 \\
(0.015)\end{array}$ \\
\hline Basic * Year 5 & $\begin{array}{c}0.113^{* * *} \\
(0.017)\end{array}$ & $\begin{array}{c}0.117^{* * *} \\
(0.021)\end{array}$ & $\begin{array}{c}0.120^{* * *} \\
(0.023)\end{array}$ & $\begin{array}{c}0.106^{* * *} \\
(0.018)\end{array}$ & $\begin{array}{c}0.111^{* * *} \\
(0.022)\end{array}$ & $\begin{array}{c}0.115^{* * *} \\
(0.025)\end{array}$ \\
\hline Basic * Year 10 & $\begin{array}{c}0.130^{* * *} \\
(0.025)\end{array}$ & $\begin{array}{c}0.134^{* * *} \\
(0.021)\end{array}$ & $\begin{array}{c}0.139 * * * \\
(0.023)\end{array}$ & $\begin{array}{c}0.128^{* * *} \\
(0.023)\end{array}$ & $\begin{array}{c}0.135 * * * \\
(0.025)\end{array}$ & $\begin{array}{c}0.139^{* * *} \\
(0.028)\end{array}$ \\
\hline Basic * Year 20 & & $\begin{array}{l}0.091^{*} \\
(0.051)\end{array}$ & $\begin{array}{l}0.093^{*} \\
(0.048)\end{array}$ & & $\begin{array}{l}0.084^{*} \\
(0.049)\end{array}$ & $\begin{array}{l}0.087^{*} \\
(0.049)\end{array}$ \\
\hline Basic * Year 30 & $\begin{array}{c}0.039 \\
(0.044)\end{array}$ & $\begin{array}{c}0.040 \\
(0.041)\end{array}$ & $\begin{array}{c}0.043 \\
(0.044)\end{array}$ & $\begin{array}{c}0.035 \\
(0.041)\end{array}$ & $\begin{array}{l}0.040 \\
(0.044)\end{array}$ & $\begin{array}{c}0.042 \\
(0.048)\end{array}$ \\
\hline Basic * Year 40 & & $\begin{array}{c}0.009 \\
(0.042)\end{array}$ & & & $\begin{array}{c}0.004 \\
(0.041)\end{array}$ & $\begin{array}{c}0.008 \\
(0.045)\end{array}$ \\
\hline Advanced * Year 1 & $\begin{array}{c}0.062^{* * *} \\
(0.017)\end{array}$ & $\begin{array}{c}0.066^{* * *} \\
(0.018)\end{array}$ & $\begin{array}{c}0.069^{* * *} \\
(0.020)\end{array}$ & $\begin{array}{c}0.061^{* * *} \\
(0.016)\end{array}$ & $\begin{array}{c}0.069^{* * *} \\
(0.020)\end{array}$ & $\begin{array}{c}0.071^{* * *} \\
(0.022)\end{array}$ \\
\hline Advanced * Year 5 & $\begin{array}{c}0.089^{* * *} \\
(0.018)\end{array}$ & $\begin{array}{c}0.095^{* * *} \\
(0.021)\end{array}$ & $\begin{array}{c}0.099^{* * *} \\
(0.025)\end{array}$ & $\begin{array}{c}0.078^{* * *} \\
(0.018)\end{array}$ & $\begin{array}{c}0.082^{* * *} \\
(0.020)\end{array}$ & $\begin{array}{c}0.085^{* * *} \\
(0.022)\end{array}$ \\
\hline Advanced * Year 10 & $\begin{array}{c}0.098^{* * *} \\
(0.029)\end{array}$ & $\begin{array}{c}0.106^{* * *} \\
(0.035)\end{array}$ & $\begin{array}{c}0.110^{* * *} \\
(0.036)\end{array}$ & $\begin{array}{c}0.093^{* * *} \\
(0.027)\end{array}$ & $\begin{array}{c}0.099 * * * \\
(0.031)\end{array}$ & $\begin{array}{c}0.103^{* * *} \\
(0.034)\end{array}$ \\
\hline Advanced * Year 20 & $\begin{array}{c}0.180^{* * * *} \\
(0.030)\end{array}$ & $\begin{array}{c}0.186^{* * * *} \\
(0.031)\end{array}$ & $\begin{array}{c}0.189^{* * * *} \\
(0.035)\end{array}$ & $\begin{array}{c}0.173^{* * *} \\
(0.029)\end{array}$ & $\begin{array}{c}0.176^{* * * *} \\
(0.031)\end{array}$ & $\begin{array}{c}0.180^{* * *} \\
(0.035)\end{array}$ \\
\hline Advanced * Year 30 & $\begin{array}{c}0.292^{* * *} \\
(0.038)\end{array}$ & $\begin{array}{c}0.295^{* * *} \\
(0.039)\end{array}$ & $\begin{array}{c}0.299^{* * *} \\
(0.041)\end{array}$ & $\begin{array}{c}0.281^{* * *} \\
(0.037)\end{array}$ & $\begin{array}{c}0.287^{* * *} \\
(0.038)\end{array}$ & $\begin{array}{c}0.290^{* * *} \\
(0.041)\end{array}$ \\
\hline Advanced $*$ Year 40 & $\begin{array}{c}0.402^{* * *} \\
(0.040)\end{array}$ & $\begin{array}{c}0.411^{* * *} \\
(0.041)\end{array}$ & $\begin{array}{c}0.415^{* * *} \\
(0.044)\end{array}$ & $\begin{array}{c}0.391^{* * *} \\
(0.035)\end{array}$ & $\begin{array}{c}0.399 * * * \\
(0.040)\end{array}$ & $\begin{array}{c}0.401^{* * *} \\
(0.042)\end{array}$ \\
\hline Plant FE & Yes & Yes & Yes & Yes & Yes & Yes \\
\hline Year FE & Yes & Yes & Yes & Yes & Yes & Yes \\
\hline $\begin{array}{l}\text { Alternative Timing } \\
\text { Observations }\end{array}$ & $\begin{array}{c}\text { Last Year } \\
12,160\end{array}$ & $\begin{array}{c}\text { First Year } \\
12,160\end{array}$ & $\begin{array}{c}\text { Mean Year } \\
12,160\end{array}$ & $\begin{array}{c}\text { Last Year } \\
12,160\end{array}$ & $\begin{array}{c}\text { First Year } \\
12,160\end{array}$ & $\begin{array}{c}\text { Mean Year } \\
12,160\end{array}$ \\
\hline
\end{tabular}

Notes. Selected annual $\beta_{t}$ coefficients and $\gamma_{t}$ coefficients from Equation 1 in columns 1 and 4 , and imputing the distance from Soviet intervention for the comparison plants using the first, instead of the last, year in which a plant received the Soviet transfer in columns 2 and 5; and using the mean year in which plants received the Soviet transfer in columns 3 and 6. Data are provided at the plant level from the Steel Association Reports from 1949 to 2000. Output is logged quantities (in million tons) of steel. TFPQ is logged total factor productivity quantity, computed as $\log T F P Q=\log T F P R-\tilde{p}$, where $\widetilde{p}$ is the revenueshare weighted average of the prices of plant products, and TFPR is calculated using Gandhi et al. (2020)'s method. Standard errors are clustered at the plant level. ${ }^{* * *} \mathrm{p}<0.01,{ }^{* *} \mathrm{p}<0.05,{ }^{*} \mathrm{p}<0.1$. 
Table A.7: Robustness Checks of Main Results to Alternative Clustering

\begin{tabular}{|c|c|c|c|c|c|c|c|c|c|c|}
\hline & \multicolumn{5}{|c|}{ "Log Output (1-5) } & \multicolumn{5}{|c|}{ Log TFPQ (6-10) } \\
\hline & $(1)$ & $(2)$ & (3) & $(4)$ & (5) & $(6)$ & $(7)$ & $(8)$ & (9) & $(10)$ \\
\hline Basic $^{*}$ Year 1 & $\begin{array}{c}0.002 \\
(0.018)\end{array}$ & $\begin{array}{c}0.002 \\
(0.017)\end{array}$ & $\begin{array}{c}0.002 \\
(0.015)\end{array}$ & $\begin{array}{c}0.002 \\
(0.014)\end{array}$ & $\begin{array}{c}0.002 \\
(0.012)\end{array}$ & $\begin{array}{c}0.001 \\
(0.017)\end{array}$ & $\begin{array}{c}0.001 \\
(0.015)\end{array}$ & $\begin{array}{c}0.001 \\
(0.012)\end{array}$ & $\begin{array}{c}0.001 \\
(0.011)\end{array}$ & $\begin{array}{c}0.001 \\
(0.010)\end{array}$ \\
\hline Basic * Year 5 & $\begin{array}{c}0.113^{* * *} \\
(0.017)\end{array}$ & $\begin{array}{c}0.113^{* * *} \\
(0.015)\end{array}$ & $\begin{array}{c}0.113^{* * *} \\
(0.014)\end{array}$ & $\begin{array}{c}0.113^{* * *} \\
(0.012)\end{array}$ & $\begin{array}{c}0.113^{* * *} \\
(0.011)\end{array}$ & $\begin{array}{c}0.106^{* * *} \\
(0.018)\end{array}$ & $\begin{array}{c}0.106^{* * *} \\
(0.017)\end{array}$ & $\begin{array}{c}0.106^{* * *} \\
(0.015)\end{array}$ & $\begin{array}{c}0.106^{* * *} \\
(0.014)\end{array}$ & $\begin{array}{c}0.106^{* * *} \\
(0.013)\end{array}$ \\
\hline Basic * Year 10 & $\begin{array}{c}0.130^{* * *} \\
(0.025)\end{array}$ & $\begin{array}{c}0.130^{* * *} \\
(0.022)\end{array}$ & $\begin{array}{c}0.130 * * * \\
(0.020)\end{array}$ & $\begin{array}{c}0.130^{* * *} \\
(0.019)\end{array}$ & $\begin{array}{c}0.130^{* * *} \\
(0.019)\end{array}$ & $\begin{array}{c}0.128^{* * *} \\
(0.023)\end{array}$ & $\begin{array}{c}0.128^{* * *} \\
(0.020)\end{array}$ & $\begin{array}{c}0.128^{* * *} \\
(0.019)\end{array}$ & $\begin{array}{c}0.128^{* * *} \\
(0.017)\end{array}$ & $\begin{array}{c}0.128^{* * *} \\
(0.018)\end{array}$ \\
\hline Basic * Year 20 & $\begin{array}{l}0.085^{*} \\
(0.046)\end{array}$ & $\begin{array}{l}0.085^{*} \\
(0.045)\end{array}$ & $\begin{array}{l}0.085^{*} \\
(0.044)\end{array}$ & $\begin{array}{l}0.085^{*} \\
(0.045)\end{array}$ & & & $\begin{array}{l}0.081^{*} \\
(0.046)\end{array}$ & & & $\begin{array}{l}0.081^{*} \\
(0.043)\end{array}$ \\
\hline Basic * Year 30 & $\begin{array}{c}0.039 \\
(0.044)\end{array}$ & $\begin{array}{c}0.039 \\
(0.043)\end{array}$ & $\begin{array}{c}0.039 \\
(0.042)\end{array}$ & $\begin{array}{c}0.039 \\
(0.040)\end{array}$ & $\begin{array}{c}0.039 \\
(0.035)\end{array}$ & $\begin{array}{c}0.035 \\
(0.041)\end{array}$ & $\begin{array}{c}0.035 \\
(0.040)\end{array}$ & $\begin{array}{c}0.035 \\
(0.039)\end{array}$ & $\begin{array}{c}0.035 \\
(0.035)\end{array}$ & $\begin{array}{c}0.035 \\
(0.031)\end{array}$ \\
\hline Basic * Year 40 & & & & & $\begin{array}{c}0.009 \\
(0.035)\end{array}$ & $\begin{array}{c}0.001 \\
(0.043)\end{array}$ & $\begin{array}{c}0.001 \\
(0.041)\end{array}$ & $\begin{array}{c}0.001 \\
(0.040)\end{array}$ & $\begin{array}{c}0.001 \\
(0.039)\end{array}$ & $\begin{array}{c}0.001 \\
(0.037)\end{array}$ \\
\hline Advanced * Year 1 & $\begin{array}{c}0.062^{* * *} \\
(0.017)\end{array}$ & $\begin{array}{c}0.062^{* * *} \\
(0.016)\end{array}$ & $\begin{array}{c}0.062 * * * \\
(0.014)\end{array}$ & $\begin{array}{c}0.062^{* * *} \\
(0.013)\end{array}$ & $\begin{array}{c}0.062 * * * \\
(0.011)\end{array}$ & $\begin{array}{c}0.061^{* * *} \\
(0.016)\end{array}$ & $\begin{array}{c}0.061^{* * *} \\
(0.015)\end{array}$ & $\begin{array}{c}0.061^{* * *} \\
(0.013)\end{array}$ & $\begin{array}{c}0.061^{* * *} \\
(0.011)\end{array}$ & $\begin{array}{c}0.061^{* * *} \\
(0.010)\end{array}$ \\
\hline Advanced * Year 5 & $\begin{array}{c}0.089^{* * *} \\
(0.018)\end{array}$ & $\begin{array}{c}0.089^{* * *} \\
(0.015)\end{array}$ & $\begin{array}{c}0.089^{* * *} \\
(0.014)\end{array}$ & $\begin{array}{c}0.089^{* * *} \\
(0.012)\end{array}$ & $\begin{array}{c}0.089^{* * *} \\
(0.010)\end{array}$ & $\begin{array}{c}0.078^{* * *} \\
(0.018)\end{array}$ & $\begin{array}{c}0.078^{* * *} \\
(0.016)\end{array}$ & $\begin{array}{c}0.078^{* * *} \\
(0.014)\end{array}$ & $\begin{array}{c}0.078^{* * *} \\
(0.013)\end{array}$ & $\begin{array}{c}0.078^{* * *} \\
(0.012)\end{array}$ \\
\hline Advanced * Year 10 & $\begin{array}{c}0.098^{* * *} \\
(0.029)\end{array}$ & $\begin{array}{c}0.098^{* * *} \\
(0.025)\end{array}$ & $\begin{array}{c}0.098^{* * *} \\
(0.023)\end{array}$ & $\begin{array}{c}0.098^{* * *} \\
(0.020)\end{array}$ & $\begin{array}{c}0.098^{* * *} \\
(0.019)\end{array}$ & $\begin{array}{c}0.093^{* * *} \\
(0.026)\end{array}$ & $\begin{array}{c}0.093^{* * *} \\
(0.024)\end{array}$ & $\begin{array}{c}0.093^{* * *} \\
(0.022)\end{array}$ & $\begin{array}{c}0.093^{* * *} \\
(0.021)\end{array}$ & $\begin{array}{c}0.093^{* * *} \\
(0.017)\end{array}$ \\
\hline Advanced * Year 20 & $\begin{array}{c}0.180^{* * *} \\
(0.030)\end{array}$ & $\begin{array}{c}0.180^{* * *} \\
(0.029)\end{array}$ & $\begin{array}{c}0.180^{* * *} \\
(0.026)\end{array}$ & $\begin{array}{c}0.180^{* * *} \\
(0.024)\end{array}$ & $\begin{array}{c}0.180^{* * *} \\
(0.023)\end{array}$ & $\begin{array}{c}0.173^{* * *} \\
(0.029)\end{array}$ & $\begin{array}{c}0.173^{* * *} \\
(0.025)\end{array}$ & $\begin{array}{c}0.173^{* * *} \\
(0.022)\end{array}$ & $\begin{array}{c}0.173^{* * *} \\
(0.019)\end{array}$ & $\begin{array}{c}0.173^{* * *} \\
(0.017)\end{array}$ \\
\hline Advanced * Year 30 & $\begin{array}{c}0.292^{* * *} \\
(0.038)\end{array}$ & $\begin{array}{c}0.292^{* * *} \\
(0.036)\end{array}$ & $\begin{array}{c}0.292^{* * *} \\
(0.033)\end{array}$ & $\begin{array}{c}0.292^{* * *} \\
(0.030)\end{array}$ & $\begin{array}{c}0.292^{* * *} \\
(0.029)\end{array}$ & $\begin{array}{c}0.281^{* * *} \\
(0.037)\end{array}$ & $\begin{array}{c}0.281^{* * *} \\
(0.035)\end{array}$ & $\begin{array}{c}0.281^{* * *} \\
(0.033)\end{array}$ & $\begin{array}{c}0.281^{* * *} \\
(0.031)\end{array}$ & $\begin{array}{c}0.281^{* * * *} \\
(0.029)\end{array}$ \\
\hline Advanced * Year 40 & $\begin{array}{c}0.402^{* * *} \\
(0.040)\end{array}$ & $\begin{array}{c}0.402^{* * *} \\
(0.038)\end{array}$ & $\begin{array}{c}0.402^{* * *} \\
(0.035)\end{array}$ & $\begin{array}{c}0.402^{* * *} \\
(0.033)\end{array}$ & $\begin{array}{c}0.402^{* * *} \\
(0.031)\end{array}$ & $\begin{array}{c}0.391 * * * \\
(0.035)\end{array}$ & $\begin{array}{c}0.391^{* * *} \\
(0.034)\end{array}$ & $\begin{array}{c}0.391^{* * *} \\
(0.031)\end{array}$ & $\begin{array}{c}0.391^{* * *} \\
(0.029)\end{array}$ & $\begin{array}{c}0.391^{* * *} \\
(0.027)\end{array}$ \\
\hline Cluster: Plant & Yes & No & No & No & No & Yes & No & No & No & No \\
\hline Cluster: Firm & No & Yes & No & No & No & No & Yes & No & No & No \\
\hline Cluster: County & No & No & Yes & No & No & No & No & Yes & No & No \\
\hline Cluster: Firm-Year & No & No & No & Yes & No & No & No & No & Yes & No \\
\hline Cluster: County-Year & No & No & No & No & Yes & No & No & No & No & Yes \\
\hline Observations & 12,160 & 12,160 & 12,160 & 12,160 & 12,160 & 12,160 & 12,160 & 12,160 & 12,160 & 12,160 \\
\hline
\end{tabular}

Notes. Selected annual $\beta_{t}$ coefficients and $\gamma_{t}$ coefficients from Equation 1 with standard errors clustered at the plant level (columns 1 and 6), wild bootstrapped at the firm level with 1,000 replications (Cameron et al., 2008, columns 2 and 7), clustered at the county level (columns 3 and 8), at the firm-year level (columns 4 and 9), and at the county-year level (columns 5 and 10). Data are provided at the plant level from the Steel Association Reports from 1949 to 2000. Output is logged quantities (in million tons) of steel. TFPQ is $\operatorname{logged~total~factor~productivity~quantity,~computed~as~} \log T F P Q=\log T F P R-\tilde{p}$, where $\widetilde{p}$ is the revenueshare weighted average of the prices of plant products, and TFPR is calculated using Gandhi et al. (2020)'s method. Standard errors are clustered at the plant level. ${ }^{* * *} \mathrm{p}<0.01,{ }^{* *} \mathrm{p}<0.05,{ }^{*} \mathrm{p}<0.1$. 
Table A.8: Effects of Technology Transfer in 1985 and 1998-2013

\begin{tabular}{lcccccc}
\hline \hline & \multicolumn{2}{c}{ Log Value Added } & \multicolumn{2}{c}{ Log TFPR } & \multicolumn{2}{c}{ Log Employees } \\
\hline & 1985 & $1998-2013$ & 1985 & $1998-2013$ & 1985 & $1998-2013$ \\
& $(1)$ & $(2)$ & $(3)$ & $(4)$ & $(5)$ & $(6)$ \\
\cline { 2 - 7 } Basic & 0.047 & 0.008 & 0.038 & 0.006 & 0.006 & 0.008 \\
& $(0.043)$ & $(0.010)$ & $(0.023)$ & $(0.011)$ & $(0.008)$ & $(0.016)$ \\
Advanced & $0.347^{* * *}$ & $0.419^{* * *}$ & $0.333^{* * *}$ & $0.401^{* * *}$ & 0.003 & 0.009 \\
& $(0.053)$ & $(0.069)$ & $(0.048)$ & $(0.058)$ & $(0.005)$ & $(0.010)$ \\
\hline Sector-Province FE & Yes & No & Yes & No & Yes & No \\
Sector-Province-Year FE & No & Yes & No & Yes & No & Yes \\
Observations & 139 & 2,085 & 139 & 2,085 & 139 & 2,085 \\
\hline \hline
\end{tabular}

Notes. $\beta$ and $\gamma$ coefficients estimated from Equation 2. Data are provided at the plant level from the Second Annual Survey in 1985 (columns 1, 3 and 5) and from the China Industrial Enterprises database between 1998 and 2013 (columns 2, 4 and 6). Log Value Added is measured in 2020 US\$ millions, reevaluated at 1 RMB in 1955=3.9605 USD in 2020; Log TFPR is logged total factor productivity revenue computed with the Gandhi et al. (2020)'s method; Log Employees is logged thousands of employees per plant. Standard errors are clustered at the firm level. ${ }^{* * *} \mathrm{p}<0.01,{ }^{* *} \mathrm{p}<0.05,{ }^{*} \mathrm{p}<0.1$. 
Table A.9: Government Loans and Accessibility

\begin{tabular}{|c|c|c|c|c|}
\hline Panel A & $\begin{array}{l}\text { Log Loans } \\
\text { (1) }\end{array}$ & $\begin{array}{c}\text { Log Transfers } \\
(2)\end{array}$ & $\begin{array}{c}\text { Log Distance Road } \\
(3)\end{array}$ & $\begin{array}{c}\text { Log Distance Railroad } \\
(4)\end{array}$ \\
\hline Basic * Year 1 & $\begin{array}{c}0.004 \\
(0.006)\end{array}$ & $\begin{array}{l}-0.009 \\
(0.010)\end{array}$ & $\begin{array}{l}-0.003 \\
(0.006)\end{array}$ & $\begin{array}{l}-0.005 \\
(0.007)\end{array}$ \\
\hline Basic * Year 5 & $\begin{array}{c}0.005 \\
(0.009)\end{array}$ & $\begin{array}{l}-0.006 \\
(0.009)\end{array}$ & $\begin{array}{l}-0.002 \\
(0.004)\end{array}$ & $\begin{array}{c}0.009 \\
(0.013)\end{array}$ \\
\hline Basic * Year 10 & $\begin{array}{l}-0.003 \\
(0.004)\end{array}$ & $\begin{array}{l}-0.008 \\
(0.008)\end{array}$ & $\begin{array}{l}-0.004 \\
(0.006)\end{array}$ & $\begin{array}{l}-0.003 \\
(0.005)\end{array}$ \\
\hline Basic * Year 20 & $\begin{array}{l}-0.007 \\
(0.013)\end{array}$ & $\begin{array}{c}0.004 \\
(0.006)\end{array}$ & $\begin{array}{l}-0.005 \\
(0.008)\end{array}$ & $\begin{array}{l}-0.003 \\
(0.007)\end{array}$ \\
\hline Basic * Year 30 & $\begin{array}{c}0.005 \\
(0.008)\end{array}$ & $\begin{array}{l}-0.009 \\
(0.012)\end{array}$ & $\begin{array}{l}-0.003 \\
(0.008)\end{array}$ & $\begin{array}{l}-0.009 \\
(0.011)\end{array}$ \\
\hline Basic * Year 40 & $\begin{array}{l}-0.012 \\
(0.011)\end{array}$ & $\begin{array}{c}0.002 \\
(0.004)\end{array}$ & $\begin{array}{l}-0.003 \\
(0.004)\end{array}$ & $\begin{array}{c}0.009 \\
(0.017)\end{array}$ \\
\hline Advanced $*$ Year 1 & $\begin{array}{l}-0.008 \\
(0.013)\end{array}$ & $\begin{array}{l}-0.005 \\
(0.011)\end{array}$ & $\begin{array}{l}-0.007 \\
(0.010)\end{array}$ & $\begin{array}{l}-0.010 \\
(0.012)\end{array}$ \\
\hline Advanced $*$ Year 5 & $\begin{array}{l}-0.009 \\
(0.011)\end{array}$ & $\begin{array}{c}0.008 \\
(0.015)\end{array}$ & $\begin{array}{l}-0.004 \\
(0.005)\end{array}$ & $\begin{array}{c}0.004 \\
(0.008)\end{array}$ \\
\hline Advanced * Year 10 & $\begin{array}{c}0.002 \\
(0.004)\end{array}$ & $\begin{array}{l}-0.009 \\
(0.013)\end{array}$ & $\begin{array}{l}-0.005 \\
(0.008)\end{array}$ & $\begin{array}{l}-0.005 \\
(0.010)\end{array}$ \\
\hline Advanced * Year 20 & $\begin{array}{c}0.003 \\
(0.004)\end{array}$ & $\begin{array}{l}-0.007 \\
(0.017)\end{array}$ & $\begin{array}{l}-0.004 \\
(0.006)\end{array}$ & $\begin{array}{l}-0.005 \\
(0.012)\end{array}$ \\
\hline Advanced * Year 30 & $\begin{array}{l}-0.012 \\
(0.015)\end{array}$ & $\begin{array}{c}0.002 \\
(0.007)\end{array}$ & $\begin{array}{l}-0.003 \\
(0.005)\end{array}$ & $\begin{array}{l}-0.003 \\
(0.007)\end{array}$ \\
\hline Advanced * Year 40 & $\begin{array}{l}-0.007 \\
(0.008)\end{array}$ & $\begin{array}{l}0.006 \\
(0.015)\end{array}$ & $\begin{array}{l}-0.009 \\
(0.011)\end{array}$ & $\begin{array}{c}0.004 \\
(0.006)\end{array}$ \\
\hline Plant FE & Yes & Yes & No & No \\
\hline Firm FE & No & No & Yes & Yes \\
\hline Year FE & Yes & Yes & Yes & Yes \\
\hline Steel Only & Yes & Yes & No & No \\
\hline All Industries & No & No & Yes & Yes \\
\hline Observations & 12,160 & 12,160 & 5,560 & 5,560 \\
\hline
\end{tabular}

Panel B

Log Loans
$(2)$ $-0.025$ $(0.043)$
Log Transfers
(4)

$-0.016$

$(0.018)$

$-0.021$

$(0.024)$

\begin{tabular}{lcccc} 
Advanced & -0.017 & -0.019 & -0.022 & -0.021 \\
& $(0.021)$ & $(0.022)$ & $(0.030)$ & $(0.024)$ \\
\hline Years & 1985 & $1998-2013$ & 1985 & $1998-2013$ \\
Observations & 139 & 2,085 & 139 & 2,085 \\
\hline
\end{tabular}

Notes. Selected annual $\beta_{t}$ coefficients and $\gamma_{t}$ coefficients from Equation 1 in Panel A and $\beta$ and $\gamma$ coefficients from Equation 2 in Panel B. Data are provided at the plant level from Steel Association Reports from 1949 to 2000 in Panel A and at the firm level from the Second Annual Survey in 1985 in Panel B columns 1 and 3 and from the China Industrial Enterprises database between 1998 and 2013 in Panel B columns 2 and 4 . Log Loans and Log Transfers are, respectively, logged and free transfers that the government granted to treated and comparison plants and are measured in 2020 US $\$$ millions, reevaluated at 1 RMB in $1955=3.9605$ USD in 2020. Roads and Railroads measure the logged distance in $\mathrm{km}$ from the closest roads and railroads for all basic, advanced and comparison plants. Standard errors are clustered at the plant-level in Panel A and at the firm-level in Panel B. ${ }^{* * *} \mathrm{p}<0.01,{ }^{* *} \mathrm{p}<0.05,{ }_{\mathrm{p}} 14_{0.1}$. 
Table A.10: Political Connections

\begin{tabular}{|c|c|c|c|c|c|c|}
\hline & \multicolumn{3}{|c|}{ Secretaries } & \multicolumn{3}{|c|}{ Mayors } \\
\hline & $\begin{array}{c}\text { Born City } \\
\text { (1) }\end{array}$ & $\begin{array}{c}\text { University City } \\
(2)\end{array}$ & $\begin{array}{c}\text { Years Education } \\
(3)\end{array}$ & $\begin{array}{c}\text { Born City } \\
(4)\end{array}$ & $\begin{array}{c}\text { University City } \\
(5)\end{array}$ & $\begin{array}{c}\text { Years Education } \\
(6)\end{array}$ \\
\hline Basic * Year 1 & $\begin{array}{l}-0.004 \\
(0.006)\end{array}$ & $\begin{array}{l}-0.004 \\
(0.008)\end{array}$ & $\begin{array}{l}-0.005 \\
(0.005)\end{array}$ & $\begin{array}{l}-0.007 \\
(0.009)\end{array}$ & $\begin{array}{l}-0.008 \\
(0.009)\end{array}$ & $\begin{array}{l}-0.009 \\
(0.012)\end{array}$ \\
\hline Basic * Year 5 & $\begin{array}{l}-0.003 \\
(0.005)\end{array}$ & $\begin{array}{l}-0.001 \\
(0.003)\end{array}$ & $\begin{array}{l}-0.006 \\
(0.007)\end{array}$ & $\begin{array}{l}-0.008 \\
(0.011)\end{array}$ & $\begin{array}{l}-0.010 \\
(0.011)\end{array}$ & $\begin{array}{l}-0.007 \\
(0.013)\end{array}$ \\
\hline Basic * Year 10 & $\begin{array}{l}-0.002 \\
(0.005)\end{array}$ & $\begin{array}{l}-0.005 \\
(0.008)\end{array}$ & $\begin{array}{l}-0.004 \\
(0.003)\end{array}$ & $\begin{array}{l}-0.006 \\
(0.007)\end{array}$ & $\begin{array}{l}-0.006 \\
(0.007)\end{array}$ & $\begin{array}{l}-0.006 \\
(0.009)\end{array}$ \\
\hline Basic * Year 20 & $\begin{array}{l}-0.003 \\
(0.004)\end{array}$ & $\begin{array}{l}-0.004 \\
(0.006)\end{array}$ & $\begin{array}{l}-0.005 \\
(0.004)\end{array}$ & $\begin{array}{l}-0.005 \\
(0.007)\end{array}$ & $\begin{array}{l}-0.008 \\
(0.011)\end{array}$ & $\begin{array}{l}-0.004 \\
(0.006)\end{array}$ \\
\hline Basic * Year 30 & $\begin{array}{l}-0.006 \\
(0.005)\end{array}$ & $\begin{array}{l}-0.008 \\
(0.012)\end{array}$ & $\begin{array}{l}-0.006 \\
(0.005)\end{array}$ & $\begin{array}{l}-0.009 \\
(0.012)\end{array}$ & $\begin{array}{l}-0.010 \\
(0.010)\end{array}$ & $\begin{array}{l}-0.008 \\
(0.010)\end{array}$ \\
\hline Basic * Year 40 & $\begin{array}{l}-0.002 \\
(0.003)\end{array}$ & $\begin{array}{l}-0.005 \\
(0.006)\end{array}$ & $\begin{array}{l}-0.010 \\
(0.011)\end{array}$ & $\begin{array}{l}-0.008 \\
(0.010)\end{array}$ & $\begin{array}{l}-0.008 \\
(0.011)\end{array}$ & $\begin{array}{l}-0.009 \\
(0.012)\end{array}$ \\
\hline Advanced*Year 1 & $\begin{array}{l}-0.004 \\
(0.006)\end{array}$ & $\begin{array}{l}-0.003 \\
(0.005)\end{array}$ & $\begin{array}{l}-0.014 \\
(0.012)\end{array}$ & $\begin{array}{l}-0.009 \\
(0.014)\end{array}$ & $\begin{array}{l}-0.009 \\
(0.010)\end{array}$ & $\begin{array}{l}-0.008 \\
(0.009)\end{array}$ \\
\hline Advanced*Year 5 & $\begin{array}{l}-0.001 \\
(0.002)\end{array}$ & $\begin{array}{l}-0.002 \\
(0.006)\end{array}$ & $\begin{array}{l}-0.010 \\
(0.011)\end{array}$ & $\begin{array}{l}-0.011 \\
(0.012)\end{array}$ & $\begin{array}{l}-0.008 \\
(0.011)\end{array}$ & $\begin{array}{l}-0.012 \\
(0.015)\end{array}$ \\
\hline Advanced*Year 10 & $\begin{array}{c}0.005 \\
(0.008)\end{array}$ & $\begin{array}{l}-0.002 \\
(0.003)\end{array}$ & $\begin{array}{l}-0.015 \\
(0.017)\end{array}$ & $\begin{array}{c}0.013 \\
(0.015)\end{array}$ & $\begin{array}{l}-0.011 \\
(0.014)\end{array}$ & $\begin{array}{l}-0.011 \\
(0.010)\end{array}$ \\
\hline Advanced*Year 20 & $\begin{array}{l}-0.001 \\
(0.003)\end{array}$ & $\begin{array}{l}-0.002 \\
(0.002)\end{array}$ & $\begin{array}{l}-0.012 \\
(0.016)\end{array}$ & $\begin{array}{l}-0.009 \\
(0.010)\end{array}$ & $\begin{array}{l}-0.009 \\
(0.008)\end{array}$ & $\begin{array}{l}-0.013 \\
(0.013)\end{array}$ \\
\hline Advanced*Year 30 & $\begin{array}{l}-0.004 \\
(0.005)\end{array}$ & $\begin{array}{l}-0.005 \\
(0.006)\end{array}$ & $\begin{array}{l}-0.011 \\
(0.013)\end{array}$ & $\begin{array}{l}-0.007 \\
(0.009)\end{array}$ & $\begin{array}{l}-0.007 \\
(0.009)\end{array}$ & $\begin{array}{l}-0.012 \\
(0.016)\end{array}$ \\
\hline Advanced*Year 40 & $\begin{array}{l}-0.003 \\
(0.008)\end{array}$ & $\begin{array}{l}-0.007 \\
(0.008)\end{array}$ & $\begin{array}{l}-0.010 \\
(0.012)\end{array}$ & $\begin{array}{l}-0.010 \\
(0.012)\end{array}$ & $\begin{array}{l}-0.011 \\
(0.013)\end{array}$ & $\begin{array}{l}-0.009 \\
(0.013)\end{array}$ \\
\hline Province-Year FE & Yes & Yes & Yes & Yes & Yes & Yes \\
\hline All Industries & Yes & Yes & Yes & Yes & Yes & Yes \\
\hline Observations & 5,265 & 5,265 & 5,265 & 5,265 & 5,265 & 5,265 \\
\hline
\end{tabular}

Notes. Selected annual $\beta_{t}$ coefficients and $\gamma_{t}$ coefficients from Equation 1 for all basic, advanced and comparison plants. Born City and University City are indicators for secretaries of the Municipal Party Committee (columns 1-2) and mayors (columns 4-5) assigned to a city they were born in or studied in. Years Education is the logged number of secretaries' (column 3) and mayors' (column 6) years of education. Data are provided at the city level from the People's Daily Online database between 1949 and 2013. Standard errors are clustered at the plant-level. ${ }^{* * *} \mathrm{p}<0.01,{ }^{* *} \mathrm{p}<0.05,{ }^{*} \mathrm{p}<0.1$. 
Table A.11: County-Level Government Investments

\begin{tabular}{|c|c|c|c|c|c|}
\hline & \multicolumn{3}{|c|}{ Log Investment } & \multirow{2}{*}{$\begin{array}{l}\text { Log Other Projects } \\
\text { (4) }\end{array}$} & \multirow{2}{*}{$\begin{array}{c}\text { Log Infrastructure } \\
(5)\end{array}$} \\
\hline & $\begin{array}{l}\text { All } \\
(1)\end{array}$ & $\begin{array}{c}\text { Related Industries } \\
\text { (2) }\end{array}$ & $\begin{array}{c}\text { Unrelated Industries } \\
(3)\end{array}$ & & \\
\hline \multirow[t]{2}{*}{ Basic * Post } & -0.019 & -0.011 & 0.015 & -0.014 & 0.021 \\
\hline & $(0.025)$ & $(0.044)$ & $(0.028)$ & $(0.015)$ & $(0.038)$ \\
\hline \multirow[t]{2}{*}{ Advanced $*$ Post } & -0.022 & 0.009 & -0.005 & 0.012 & 0.014 \\
\hline & $(0.023)$ & $(0.003)$ & $(0.010)$ & $(0.011)$ & $(0.020)$ \\
\hline County-Year FE & Yes & Yes & Yes & Yes & Yes \\
\hline Observations & 3,240 & 3,240 & 3,240 & 3,240 & 3,240 \\
\hline
\end{tabular}

Notes. Basic is an indicator equal to one for counties where plants that received a basic transfer were located. Advanced is an indicator equal to one for counties where plants that received an advanced transfer were located. Post Log Investment is logged government investment in all industries, in industries related to the 156 Projects and in unrelated industries. Log Other Projects is logged number of industrial projects financed by the Chinese government to promote industrialization after the end of the Sino-Soviet Alliance. Log Infrastructure is logged government investment in infrastructure. Data are provided at the county level from the Statistical Yearbooks between 1949 and 2008. Standard errors are clustered at the county level. $* * * \mathrm{p}<0.01,{ }^{*} * \mathrm{p}<0.05,{ }^{*} \mathrm{p}<0.1$.

Table A.12: Correlation between Comparison Plants and Other Steel Plants

\begin{tabular}{|c|c|c|c|}
\hline & $\begin{array}{c}\text { Log Output } \\
\text { (1) }\end{array}$ & $\begin{array}{c}\text { Log TFPQ } \\
(2)\end{array}$ & $\begin{array}{c}\text { Log Workers } \\
(3)\end{array}$ \\
\hline \multirow[t]{2}{*}{ Comparison $*$ Year 1} & 0.022 & 0.011 & 0.010 \\
\hline & $(0.015)$ & $(0.010)$ & $(0.008)$ \\
\hline \multirow[t]{2}{*}{ Comparison* Year 5} & $0.029^{* * *}$ & $0.012^{* * *}$ & $0.015^{* * *}$ \\
\hline & $(0.010)$ & $(0.004)$ & $(0.005)$ \\
\hline \multirow[t]{2}{*}{ Comparison* Year 10} & $0.033^{* * *}$ & $0.014^{* * *}$ & $0.020^{* * *}$ \\
\hline & $(0.011)$ & $(0.005)$ & $(0.006)$ \\
\hline \multirow[t]{2}{*}{ Comparison* Year 20} & $0.035^{* * *}$ & $0.015^{* * *}$ & $0.022^{* * *}$ \\
\hline & $(0.007)$ & $(0.005)$ & $(0.007)$ \\
\hline \multirow[t]{2}{*}{ Comparison* Year 30} & $0.039^{* * *}$ & $0.014^{* * *}$ & $0.023^{* * *}$ \\
\hline & $(0.010)$ & $(0.004)$ & $(0.006)$ \\
\hline \multirow[t]{2}{*}{ Comparison* Year 40} & $0.035^{* * *}$ & $0.010^{* * *}$ & $0.020 * * *$ \\
\hline & $(0.007)$ & $(0.003)$ & $(0.005)$ \\
\hline Plant FE & Yes & Yes & Yes \\
\hline Year FE & Yes & Yes & Yes \\
\hline Observations & 36,220 & 36,220 & 36,220 \\
\hline
\end{tabular}

Notes. The sample includes comparison plants and steel plants built by the Chinese government under industrial projects started after the Sino-Soviet Split. Comparison is an indicator for plants built as part of the 156 Projects. Log Output is logged quantities (in tons) of steel. Log TFPQ is logged total factor productivity quantity, computed as $\log T F P Q=\log T F P R-\tilde{p}$, where $\tilde{p}$ is the revenue share weighted average of the prices of plant products and TFPR is calculated using Gandhi et al. (2020)'s method. Log Workers is logged number of workers. Data are provided at the plant level from the Steel Association Reports between 1949 and 2000. Standard errors are clustered at the plant-level. *** $\mathrm{p}<0.01, * * \mathrm{p}<0.05$, * $\mathrm{p}<0.1$. 
Table A.13: Bounding Based on Correlation Between Observables and Unobservables

\begin{tabular}{|c|c|c|c|c|c|c|c|c|}
\hline & $\begin{array}{l}\text { Main Results } \\
(1)\end{array}$ & $\begin{array}{c}\delta=0.1 \\
(2)\end{array}$ & $\begin{array}{c}\delta=0.2 \\
(3)\end{array}$ & $\begin{array}{c}\delta=0.4 \\
(4)\end{array}$ & $\begin{array}{c}\delta=0.6 \\
(5)\end{array}$ & $\begin{array}{c}\delta=0.8 \\
(6)\end{array}$ & $\begin{array}{c}\delta=1 \\
(7)\end{array}$ & $\begin{array}{c}\delta \text { for } \beta=0 \\
(8)\end{array}$ \\
\hline \multicolumn{9}{|l|}{ Panel A: Output } \\
\hline Basic * Year 1 & 0.002 & 0.002 & 0.002 & 0.003 & 0.002 & 0.002 & 0.002 & \\
\hline Basic * Year 5 & 0.113 & 0.109 & 0.108 & 0.105 & 0.103 & 0.101 & 0.099 & 8.34 \\
\hline Basic * Year 10 & 0.130 & 0.124 & 0.122 & 0.121 & 0.120 & 0.118 & 0.117 & 9.32 \\
\hline Basic * Year 20 & 0.085 & 0.083 & 0.081 & 0.079 & 0.077 & 0.074 & 0.073 & 9.87 \\
\hline Basic * Year 30 & 0.039 & 0.036 & 0.033 & 0.029 & 0.026 & 0.024 & 0.021 & \\
\hline Basic $^{*}$ Year 40 & 0.009 & 0.008 & 0.007 & 0.006 & 0.007 & 0.005 & 0.007 & \\
\hline Advanced * Year 1 & 0.062 & 0.057 & 0.055 & 0.053 & 0.051 & 0.049 & 0.046 & 10.98 \\
\hline Advanced $*$ Year 5 & 0.089 & 0.087 & 0.085 & 0.082 & 0.079 & 0.075 & 0.071 & 11.77 \\
\hline Advanced $*$ Year 10 & 0.098 & 0.095 & 0.093 & 0.090 & 0.082 & 0.080 & 0.077 & 12.54 \\
\hline Advanced * Year 20 & 0.180 & 0.177 & 0.173 & 0.171 & 0.169 & 0.167 & 0.163 & 14.61 \\
\hline Advanced $*$ Year 30 & 0.292 & 0.288 & 0.285 & 0.283 & 0.278 & 0.276 & 0.270 & 16.87 \\
\hline Advanced * Year 40 & 0.402 & 0.398 & 0.395 & 0.392 & 0.390 & 0.387 & 0.381 & 19.12 \\
\hline \multicolumn{9}{|l|}{ Panel B: TFPQ } \\
\hline Basic * Year 1 & 0.001 & 0.001 & 0.001 & 0.002 & 0.001 & 0.001 & 0.001 & \\
\hline Basic $^{*}$ Year 5 & 0.108 & 0.105 & 0.102 & 0.100 & 0.098 & 0.095 & 0.091 & 8.01 \\
\hline Basic * Year 10 & 0.128 & 0.122 & 0.120 & 0.119 & 0.1150 & 0.111 & 0.108 & 8.93 \\
\hline Basic * Year 20 & 0.081 & 0.080 & 0.077 & 0.075 & 0.071 & 0.070 & 0.069 & 9.57 \\
\hline Basic * Year 30 & 0.035 & 0.033 & 0.031 & 0.025 & 0.023 & 0.021 & 0.018 & \\
\hline Basic $^{*}$ Year 40 & 0.002 & 0.002 & 0.002 & 0.002 & 0.002 & 0.002 & 0.01 & \\
\hline Advanced * Year 1 & 0.061 & 0.055 & 0.051 & 0.048 & 0.046 & 0.044 & 0.041 & 12.17 \\
\hline Advanced $*$ Year 5 & 0.078 & 0.073 & 0.069 & 0.065 & 0.063 & 0.061 & 0.059 & 12.67 \\
\hline Advanced ${ }^{*}$ Year 10 & 0.093 & 0.092 & 0.089 & 0.087 & 0.081 & 0.079 & 0.072 & 14.91 \\
\hline Advanced * Year 20 & 0.173 & 0.170 & 0.166 & 0.162 & 0.160 & 0.158 & 0.155 & 15.32 \\
\hline Advanced * Year 30 & 0.281 & 0.278 & 0.273 & 0.270 & 0.267 & 0.262 & 0.2590 & 17.34 \\
\hline Advanced $*$ Year 40 & 0.391 & 0.387 & 0.384 & 0.381 & 0.378 & 0.373 & 0.371 & 19.06 \\
\hline
\end{tabular}

Notes. The table shows how different hypotheses on the degree of correlation between observables and unobservables affect selected $\beta_{t}$ and $\gamma_{t}$ coefficients from Equation 1. The notation follows Oster (2019). The coefficient $\delta$ is the relative degree of selection on observed and unobserved variables. $R_{\max }$ is the hypothetical $\mathrm{R}$ squared in a regression that includes both observables and unobservables. $\tilde{R}$ is the $\mathrm{R}$ squared in the regression that includes only observables (Figure 3). Oster (2019) finds that $R_{\max }=1.3$ and $\delta=1$ are appropriate bounds to calculate bias-adjusted treatment effects. Output is logged quantities (in million tons) of steel. TFPQ is logged total factor productivity quantity, computed as $\log T F P Q=\log T F P R-\tilde{p}$, where $\widetilde{p}$ is the revenue share weighted average of the prices of plant products and TFPR is calculated using the Gandhi et al. (2020)'s method. 
Table A.14: Bounding Based on Correlation Between Observables and Unobservables

\begin{tabular}{|c|c|c|c|c|c|c|c|}
\hline \multirow[b]{3}{*}{ Panel A: Output } & \multirow{2}{*}{$\begin{array}{c}\text { Main Results } \\
(1) \\
\end{array}$} & \multicolumn{6}{|c|}{$\delta=1$} \\
\hline & & $R_{\max }=1.10 \tilde{R}$ & $R_{\max }=1.20 \tilde{R}$ & $R_{\max }=1.30 \tilde{R}$ & $R_{\max }=1.40 \tilde{R}$ & $R_{\max }=1.50 \tilde{R}$ & $\begin{array}{c}R_{\max }=2 \tilde{R} \\
(7)\end{array}$ \\
\hline & & & & & & & \\
\hline Basic * Year 1 & 0.002 & 0.002 & 0.002 & 0.003 & 0.002 & 0.002 & 0.002 \\
\hline Basic $^{*}$ Year 5 & 0.113 & 0.110 & 0.107 & 0.104 & 0.102 & 0.100 & 0.096 \\
\hline Basic * Year 10 & 0.130 & 0.128 & 0.125 & 0.120 & 0.117 & 0.113 & 0.111 \\
\hline Basic * Year 20 & 0.085 & 0.082 & 0.080 & 0.077 & 0.075 & 0.073 & 0.070 \\
\hline Basic * Year 30 & 0.039 & 0.035 & 0.031 & 0.028 & 0.024 & 0.020 & 0.018 \\
\hline Basic * Year 40 & 0.009 & 0.007 & 0.006 & 0.006 & 0.006 & 0.005 & 0.003 \\
\hline Advanced $*$ Year 1 & 0.062 & 0.055 & 0.053 & 0.050 & 0.049 & 0.047 & 0.041 \\
\hline Advanced $*$ Year 5 & 0.089 & 0.085 & 0.081 & 0.080 & 0.074 & 0.073 & 0.070 \\
\hline Advanced $*$ Year 10 & 0.098 & 0.095 & 0.090 & 0.088 & 0.085 & 0.081 & 0.079 \\
\hline Advanced $*$ Year 20 & 0.180 & 0.176 & 0.172 & 0.168 & 0.167 & 0.166 & 0.162 \\
\hline Advanced $*$ Year 30 & 0.292 & 0.285 & 0.283 & 0.281 & 0.277 & 0.274 & 0.271 \\
\hline Advanced $*$ Year 40 & 0.402 & 0.397 & 0.394 & 0.390 & 0.387 & 0.385 & 0.379 \\
\hline Panel B: TFPQ & & & & & & & \\
\hline Basic * Year 1 & 0.001 & 0.001 & 0.001 & 0.002 & 0.001 & 0.002 & 0.002 \\
\hline Basic * Year 5 & 0.108 & 0.106 & 0.103 & 0.100 & 0.099 & 0.096 & 0.093 \\
\hline Basic * Year 10 & 0.128 & 0.124 & 0.121 & 0.118 & 0.114 & 0.111 & 0.099 \\
\hline Basic * Year 20 & 0.081 & 0.080 & 0.078 & 0.074 & 0.071 & 0.070 & 0.068 \\
\hline Basic * Year 30 & 0.035 & 0.032 & 0.029 & 0.024 & 0.020 & 0.019 & 0.014 \\
\hline Basic * Year 40 & 0.002 & 0.002 & 0.003 & 0.003 & 0.002 & 0.002 & 0.002 \\
\hline Advanced * Year 1 & 0.061 & 0.055 & 0.053 & 0.050 & 0.049 & 0.047 & 0.041 \\
\hline Advanced * Year 5 & 0.078 & 0.073 & 0.070 & 0.069 & 0.068 & 0.065 & 0.061 \\
\hline Advanced $*$ Year 10 & 0.093 & 0.090 & 0.088 & 0.084 & 0.080 & 0.079 & 0.078 \\
\hline Advanced * Year 20 & 0.173 & 0.173 & 0.170 & 0.165 & 0.161 & 0.159 & 0.155 \\
\hline Advanced * Year 30 & 0.281 & 0.285 & 0.283 & 0.281 & 0.277 & 0.274 & 0.271 \\
\hline Advanced $*$ Year 40 & 0.391 & 0.388 & 0.383 & 0.380 & 0.378 & 0.374 & 0.369 \\
\hline
\end{tabular}

Notes. The table shows how different hypotheses on $R_{\max }$ affect selected $\beta_{t}$ and $\gamma_{t}$ coefficients from Equation 1.. The notation follows Oster (2019). The coefficient $\delta$ is the relative degree of selection on observed and unobserved variables. $R_{\max }$ is the hypothetical $\mathrm{R}$ squared in a regression that includes both observables and unobservables. $\tilde{R}$ is the $\mathrm{R}$ squared in the regression that includes only observables (Figure 3 ). Oster (2019) finds that $R_{\max }=1.3$ and $\delta=1$ are appropriate bounds to calculate bias-adjusted treatment effects. Output is logged quantities (in million tons) of steel. TFPQ is logged total factor productivity quantity, computed as $\log T F P Q=\log T F P R-\tilde{p}$, where $\widetilde{p}$ is the revenue share weighted average of the prices of plant products and TFPR is calculated using the Gandhi et al. (2020)'s method. 
Table A.15: Spillover Effects in 1985

\begin{tabular}{lcccc}
\hline \hline & \multicolumn{2}{c}{ Horizontal Spillovers } & \multicolumn{2}{c}{ Vertical Spillovers } \\
\hline \multirow{4}{*}{ Basic } & Log Value Added & Log TFPR & Log Value Added & Log TFPR \\
& $(1)$ & $(2)$ & $(3)$ & $(4)$ \\
\cline { 2 - 5 } Advanced & 0.026 & 0.029 & 0.055 & 0.012 \\
& $(0.051)$ & $(0.025)$ & $(0.053)$ & $(0.022)$ \\
& $0.116^{* * *}$ & $0.109^{* * *}$ & $0.140^{* * *}$ & $0.131^{* * *}$ \\
County FE & $(0.030)$ & $(0.029)$ & $(0.028)$ & $(0.015)$ \\
Observations & Yes & Yes & Yes & Yes \\
\hline \hline
\end{tabular}

Notes. Basic is an indicator for steel plants in the same counties of steel plants that received a basic transfer. Advanced is an indicator for steel plants in the same counties of steel plants that received an advanced transfer on top of a basic transfer. Log Value Added is measured in 2020 US\$ millions, reevaluated at 1 RMB in $1955=3.9605$ USD in 2020; $\log T F P R$ is logged total factor productivity revenue computed with the Gandhi et al. (2020)'s method. Data are provided at the firm level from the Second Annual Survey in 1985. Standard errors are clustered at the firm level. ${ }^{* * *} \mathrm{p}<0.01,{ }^{* *} \mathrm{p}<0.05,{ }^{*} \mathrm{p}<0.1$.

Table A.16: County-Level Output Production by Privatized Plants, 1998-2013

\begin{tabular}{lcccccc}
\hline \hline & \multicolumn{3}{c}{ Share Privately Owned Firms } & \multicolumn{3}{c}{ Share Private Output } \\
\hline & All & Related & Unrelated & All & Related & Unrelated \\
& $(1)$ & $(2)$ & $(3)$ & $(4)$ & $(5)$ & $(6)$ \\
\cline { 2 - 7 } Basic & 0.015 & 0.012 & 0.018 & 0.016 & 0.012 & 0.004 \\
& $(0.021)$ & $(0.027)$ & $(0.009)$ & $(0.014)$ & $(0.018)$ & $(0.006)$ \\
Advanced & $0.166^{* * *}$ & $0.161^{* * *}$ & 0.005 & $0.252^{* * *}$ & $0.242^{* * *}$ & 0.011 \\
& $(0.020)$ & $(0.015)$ & $(0.005)$ & $(0.044)$ & $(0.049)$ & $(0.013)$ \\
\hline Prefecture-Year FE & Yes & Yes & Yes & Yes & Yes & Yes \\
Observations & 1,296 & 1,296 & 1,296 & 1,296 & 1,296 & 1,296 \\
\hline \hline
\end{tabular}

Notes. Basic in an indicator for counties where plants that received a basic transfer were located. Advanced in an indicator for counties where plants that received an advanced transfer were located. Share Privately Owned Firms is the per county share of firms that became private between 1998 and 2013. Share Private Steel Output Owned Firms is the per county share of output produced by privately-owned firms. Related Industries includes firms in the same, upstream, or downstream industry of basic, advanced, and comparison plants; Unrelated Industries includes firms not in the same, upstream, or downstream industry of basic, advanced, and comparison plants. Data are provided at the county level from the Statistical Yearbooks from 1998 to 2013. Standard errors are clustered at the county level. ${ }^{* * *} \mathrm{p}<0.01,{ }^{* *} \mathrm{p}<0.05,{ }^{*} \mathrm{p}<0.1$. 
Table A.17: Channels of Persistence of the Soviet Technology Transfer

\begin{tabular}{lcccc}
\hline \hline & STEM Universities & Technical Schools & College Graduates & $\begin{array}{c}\text { High-Skilled Workers } \\
(4)\end{array}$ \\
\cline { 2 - 5 } Basic & $(1)$ & $(2)$ & $(3)$ & 0.015 \\
Advanced & 0.009 & -0.010 & $(0.021)$ & $(0.011)$ \\
& $(0.013)$ & $(0.012)$ & $0.133^{* * *}$ & $0.162^{* * *}$ \\
& $0.104^{* * *}$ & $0.156^{* * *}$ & $(0.030)$ & $(0.035)$ \\
\hline Prefecture-Year FE & $(0.034)$ & $(0.041)$ & Yes & Yes \\
Observations & Yes & Yes & 1,296 & 1,296 \\
\hline \hline
\end{tabular}

Notes. Basic in an indicator for counties where plants that received a basic transfer were located. Advanced in an indicator for counties where plants that received an advanced transfer were located. STEM Universities is the share of universities offering a STEM degree per county. Technical schools is the number of technical schools per inhabitant county. College Graduates and High-Skilled Workers are the logged number of college graduates and high-skilled technicians over population per county. Data are provided at the county level from the China Education Yearbooks from 1998 to 2013. Standard errors are clustered at the county-level. ${ }^{* * *} \mathrm{p}<0.01,{ }^{* *} \mathrm{p}<0.05,{ }^{*} \mathrm{p}<0.1$. 
Table A.18: Aggregate Effects of the Soviet Technology Transfer

Panel A: Province-Level Outcomes

\begin{tabular}{lccc}
\hline \hline & $\begin{array}{c}\text { Log Ind. Output } \\
\text { Share Basic Projects * }\end{array}$ & $\begin{array}{c}\text { Log Ind. Employment } \\
(1)\end{array}$ & $\begin{array}{c}\text { Log GDP Capita } \\
(2)\end{array}$ \\
\cline { 2 - 4 } & $0.431^{* * *}$ & $0.132^{* * *}$ & $(3)$ \\
Share Advanced Projects * Post 1952 & $(0.115)$ & $(0.035)$ & $\left(0.087^{* * *}\right.$ \\
& $1.065^{* * *}$ & $0.328^{* * *}$ & $1.309^{* * *}$ \\
& $(0.278)$ & $(0.066)$ & $(0.311)$ \\
\hline Observations & 963 & 963 & 963 \\
Province FE & Yes & Yes & Yes \\
Year FE & Yes & Yes & Yes \\
\hline \hline
\end{tabular}

Panel B: Cross-Sectional Multiplier

\begin{tabular}{lcccc}
\hline \hline & \multicolumn{4}{c}{$\Delta$ GDP capita } \\
\hline \multirow{2}{*}{ Masic Projects Capita } & $(1)$ & $(2)$ & $(4)$ & $(5)$ \\
\cline { 2 - 5 } & $0.251^{* * *}$ & $0.255^{* * *}$ & $0.169^{* * *}$ & $0.173^{* * *}$ \\
Advanced Projects Capita & $(0.021)$ & $(0.024)$ & $(0.027)$ & $(0.031)$ \\
& $\left(0.083^{* * *}\right.$ & $0.589^{* * *}$ & $0.201^{* * *}$ & $0.209^{* * *}$ \\
Observations & 963 & $(0.041)$ & $(0.043)$ & $(0.042)$ \\
Province FE & Yes & 963 & 963 & 963 \\
Linear Trend & No & Yes & Yes & Yes \\
Year FE & Yes & Yes & No & Yes \\
\hline \hline
\end{tabular}

Notes. Share Basic Projects is the share of basic projects out of all projects contemplated in a given province. Share Advanced Projects is the share of advanced projects out of all projects contemplated in a given province. Post 1952 is an indicator equal to one for years after 1952. Log Ind. Output, Ind. Employment, GDP Capita, are the province-level logged industrial output, industrial employment, and GDP per capita. Basic Projects per Capita is the province investment in basic projects over population in 1949; Advanced Projects per Capita is the province investment in advanced projects over population in 1949; $\Delta$ GDP per Capita is ise variation in GDP per capita in province $p$ between year $t$ and year $t$ - 1 with $t$ $\in[1949,2008]$. Data are provided at the province level from the Statistical Yearbooks between 1949 and 2008. Standard errors are wild-bootstrapped at the province level with 1,000 replications (Cameron et al., 2008). ${ }^{* * *} \mathrm{p}<0.01,{ }^{* *} \mathrm{p}<0.05,{ }^{*} \mathrm{p}<0.1$. 


\section{B Data Collection and Dataset Construction}

In this Appendix, we provide a detailed description of our primary data sources and how we constructed the dataset, as well as a list of all the variables we use in the paper, with their definitions, aggregation level, time period, and sources (Appendix Table B.2). When needed, we also provide additional details on the variables' construction.

\section{B.1 Description of Primary Sources}

Our data collection targeted the 156 Projects approved under the Sino-Soviet Alliance between 1950 and 1957. To retrieve the list of such projects, we relied on the official signed agreements between the Soviet Union and China from the National Archives Administration of China, whose access is restricted and was occasionally granted for this paper. For each project, we collected and digitized detailed information on the project name and location, the name of the plant built, industry, size and capacity, number of workers, and whether it was completed with Soviet assistance or by China only due to the Sino-Soviet split. To make sure we collected the official agreements for all the approved projects, we also gathered data from the Selected Archival Materials on the PRC's Economy, a collection of documents on the PRC's economic development between 1949 and 1957, that includes detailed summaries of the 156 Projects. A comparison of these summaries with the official agreements reveals that the former contain no additional projects or project information beyond that found in the latter. We also compared our digitized list of projects against two historical studies in Chinese on the Sino-Soviet technology transfer program that independently collected the 156 technology transfer projects from the National Archives Administration of China as well (Zhang et al., 2003; Dong and Wu, 2004). Specifically, we checked for any differences or additional information on project name, start and completion years, and location, as well as project industry, size, and capacity. Neither Zhang et al. (2003) nor Dong and Wu (2004) provide any additional or different project information, for any of the projects, beyond that contained in our data.

We then constructed a panel dataset of plant performance and county/province outcomes, gathering data from four different sources.

Steel Association Reports (1949-2000). These reports, compiled yearly from 1949 to 2000, contain restricted data on all 94 Chinese firms in the steel industry for a total of 1,410 plants. They contain detailed information on plant quantity and type of steel products, input utilization, the specific machinery in use, capital, fixed investment, profits, and number and types of workers (unskilled workers, high-skilled workers, and engineers), all of which we manually collected and digitized in different rounds between 
August 2020 and December 2021.

Second Industrial Survey (1985). In the early 1980s, the Chinese government began implementing several reforms on market liberalization. Until then, stretching back to the RPC's founding in 1949, there had been a lack of systematic data on firm and industry structure. This survey, conducted by Statistics China in 1985, was therefore undertaken for policy makers to learn about the structure of the industries and enterprises, the products, the state of technology and equipment, the economic value of enterprises, and the quality of their workforce. This information constituted a guide for subsequent policies and reforms. As such, the survey covered more than 40 industries within the secondary sector. It is considered the most comprehensive dataset on industrial enterprises from the founding of the PRC through to the early 1990s. ${ }^{1}$ The firm-level-data portion of the survey, though still confidential today, has been declassified for this project; it covers the 7,592 largest firms operating in China in $1985 .{ }^{2}$ For each of them, the Survey gathered data on output, sales, profits, fixed assets, raw materials, total wages, number of employees, finished product inventory, main products, production equipment, and year of establishment, which we manually collected and digitized. We have also manually collected and digitized the county-level and prefecture-level industrial production data reported in the survey (which is stored internally at Statistics China, in Beijing).

China Industrial Enterprises Database (1998-2013). This database, compiled by Statistics China yearly between 1998 and 2013 to compute GDP, covers more than 1 million publicly listed and private industrial enterprises whose asset value exceeded 5 million yuan prior to 2011, and 20 million yuan after 2011. All industrial firms in the database are required to file an annual report of their production activities, as well as their accounting and financial information. Statistics China implemented strict doublechecking standards for verifying the accuracy of firm-reported information. For each firm, the database contains data on output, number of employees, profits, ownership structure, and capital investment.

Statistical Yearbook of China (1949-2000). We manually collected and digitized province-level data from all the published statistical yearbooks compiled by Statistics China between 1949 and 2000. This dataset contains province-level information on GDP,

\footnotetext{
${ }^{1}$ The First Industrial Survey was conducted in 1950, right after the PRC was founded. Its goal was estimating the "lay of the land" regarding the national industrial and mining enterprises, a basis for the recovery from the Civil War and subsequent development. However, this survey contains no firm-level data, and it predates the construction of treated and comparison plants. For this reason, we cannot employ it in our paper.

${ }^{2}$ The Second Industrial Survey reported that in 1985 there were 437,200 firms operating in China and that it collected firm-level data for the 7,592 largest ones, but the official guidelines of the survey do not provide a formal size threshold for inclusion in the survey itself. We computed that the surveyed companies comprised only $1.74 \%$ of total Chinese firms but produced $62.46 \%$ of the industrial output in 1985 .
} 
population, capital, investment, and number of workers.

Data Validation. While dealing with plant-level data, one always has to consider the possibility that the outcomes provided by the plants may not be accurate. In our context, for instance, plant supervisors may have misreported their production information to show better-than-actual performance. Two important institutional details matter here. First, our main data source, the Steel Association Reports, was highly monitored and checked by industry peers, which strongly limited the possibility of manipulation. Moreover, the officially-released aggregate production data was complied by Statistics China, a different and independent source. Manipulations were therefore more likely to occur in the latter rather than in the former reports. Second, after the Sino-Soviet Split, the Chinese government wanted to tie up loose ends with the Soviet Union as quickly as possible. As such, data manipulation should have aimed at lowering the performance of Soviet-treated plants, which would go against us finding a positive effect of the Soviet transfer. This is especially true during the Great Leap Forward, when the Chinese government wanted to show the efficacy of labor-intensive methods of industrialization, which would emphasize manpower rather than machines and capital expenditure, in stark contrast with the goals of the Soviet transfer (Clark, 1973; Lardy, 1995).

Beyond these consideration, we cross-checked our data against different sources, as follows. First, we turned to Clark (1995) who studied the Chinese steel industry, by collecting data on steel plants with a capacity of at least 100,000 tons, between 1949 and 1993. Specifically, for each plant, he estimated the minimum and the maximum yearly steel output based on the capital in use, concluding that the data from the Steel Association annual reports, our main source, appear credible. We repeat our main analysis using Clark (1995)'s data and find that our estimated coefficients using the annual reports are between the coefficients obtained using their minimum and maximum estimates (Table B.1, columns 2, 3, 6 and 7). ${ }^{3}$ Even assuming that basic and advanced plants produced at the minimum and comparison plants at the maximum level estimated by Clark (1995), we would still find a persistent effect of the advanced transfer and a short-lived effect of the basic transfer, in line with our main results (Table B.1, columns 4-8).

Second, for the Ansteel Company in Anshan, we were able to collect the plant's own production data, which it stored in its historical records (Ji, 2019). These data were intended for internal use and were not shared with the central government. When we compared this data with the data from the Steel Association Reports, we found that they are remarkably similar, with a correlation of 0.981 .

Third, we summarized the industrial output of firms in the Second Industrial Survey by

${ }^{3}$ As Clark (1995)'s study goes until 1993, we can repeat our main analysis only in the first 30 years after the Soviet transfer. 
counties and prefectures, comparing this data with the county-level and prefecture-level industrial output data reported in the survey. The two sets of data are also remarkably similar, with a correlation of 0.989 .

Fourth, we summarized the industrial output of firms in the Second Industrial Survey by provinces, comparing it with total province-level industrial output from the Statistical Yearbook of China in 1985. The two sets of data are comparable, with a correlation of 0.974 .

Data Digitization. Between August 2019 and December 2021, we employed four research assistants (undergraduate students at Tsinghua University and Peking University) to digitize the newly collected data. On top of manually performing the data entry, the research assistants were asked to cross-check their work to ensure that all the data were correctly digitized. Bo Li also personally checked the accuracy of $75 \%$ of the data entries.

\section{B.2 Matching Across Different Data Sources}

To match the plants built in the 156 Projects with their outcomes across different sources, we proceeded as follows. For plants in the steel industry, we used plant name, location, county, and province; we manually and uniquely matched all 304 steel plants eligible to participate in the technology transfer program with their annual reports. For plants in all industries, we used firm name, location, county, and province; we manually and uniquely matched all 139 firms eligible to participate in the technology transfer program with their outcomes in 1985 and between 1998 and 2013.

\section{B.3 Geolocalization of Basic, Advanced and Comparison Plants}

The Second Industrial Survey records each firm's address in 1984. To geolocalize the firms, we searched the 1984 address of each firm on Gaode Map, an online GPS browser that provides a high-quality map of China. If we could find the 1984 address in Gaode Map, we use Gaode Map's geocoding API to transfer the 1984 address to the geographic location, based on latitude and longitude. For 3,426 of the 7,592 firms covered by the Second Industrial Survey (45\%), their 1984 addresses cannot be found, because the name of streets, villages, or towns changed. We therefore manually searched these 1984 addresses on the websites of local governments that keep track of name changes and found how the addresses changed from 1984 and the corresponding current addresses. In this way, we were able to obtain the geographic locations of all the firms based on the current addresses. $^{4}$

\footnotetext{
${ }^{4}$ From 1990 to 2013, Chinese prefecture cities were subject to some jurisdictional changes. However, because we retrieve firm latitude and longitude, these changes do not affect firm geolocalization.
} 
Between 1998 and 2013, the China Industrial Enterprises database records the firm name only. We searched firms by their name in Tianyancha, a comprehensive database on all registered Chinese firms, which provides the firms' current address. We obtained all firms' addresses and used Gaode Map's geocoding API to transfer the addresses to geographic locations, based on latitudes and longitudes.

\section{B.4 Identification of Firms Economically Related to Basic, Ad- vanced and Comparison Plants}

We constructed a list of firms economically related to basic, advanced and comparison plants as follows. We retrieved each firm's two-digit industry code from the Steel Association Reports or the Second Industrial Survey, from which we observe the firm products. If firms had the same two-digit industry code of basic, advanced and comparison plants, we consider them operating in the same industry and include them in the horizontal spillover analysis. If firms had a different two-digit industry, we use the input-output tables of the closest available year to assess whether firm products were upstream or downstream, relative to the products of the treated and comparison plants. If products were neither upstream nor downstream, we consider firms not economically related to basic, advanced and comparison plants. After the National Bureau of Statistics of China (NBS) began compiling its Input-Output Tables in 1987, every five years (in the years ending with 2 and 7) it conducts the national input-output survey and compiles the benchmark input-output tables of the corresponding year. We therefore used the 1987 Input-Output Tables (for the Second Industrial Survey data of 1985) and the 1997, 2002, 2007, and 2012 Input-Output Tables (for the China Industrial Enterprises database of 1998-2013). 
Table B.1: Robustness Checks using Alternative Data Sources

\begin{tabular}{lcccccccc}
\hline \hline & \multicolumn{7}{c}{ Log Output $(1-5)$} & \multicolumn{5}{c}{ Log TFPQ $(6-10)$} \\
& $(1)$ & $(2)$ & $(3)$ & $(4)$ & $(5)$ & $(6)$ & $(7)$ & $(8)$ \\
\cline { 2 - 9 } Basic * Year 1 & 0.002 & 0.001 & 0.003 & 0.001 & 0.001 & 0.002 & 0.001 & 0.003 \\
& $(0.018)$ & $(0.016)$ & $(0.015)$ & $(0.016)$ & $(0.017)$ & $(0.013)$ & $(0.011)$ & $(0.015)$ \\
Basic * Year 5 & $0.113^{* * *}$ & $0.179^{* * *}$ & $0.101^{* * *}$ & $0.077^{* * *}$ & $0.106^{* * *}$ & $0.173^{* * *}$ & $0.096^{* * *}$ & $0.068^{* * *}$ \\
& $(0.017)$ & $(0.020)$ & $(0.015)$ & $(0.015)$ & $(0.018)$ & $(0.021)$ & $(0.012)$ & $(0.015)$ \\
Basic * Year 10 & $0.130^{* * *}$ & $0.203^{* * *}$ & $0.117^{* * *}$ & $0.085^{* * *}$ & $0.128^{* * *}$ & $0.189^{* * *}$ & $0.189^{* * *}$ & $0.076^{* * *}$ \\
& $(0.025)$ & $(0.028)$ & $(0.019)$ & $(0.022)$ & $(0.023)$ & $(0.022)$ & $(0.020)$ & $(0.018)$ \\
Basic * Year 20 & $0.085^{*}$ & $0.095^{*}$ & $0.079^{*}$ & $0.055^{*}$ & $0.081^{*}$ & $0.088^{*}$ & $0.073^{*}$ & $0.046^{*}$ \\
& $(0.046)$ & $(0.052)$ & $(0.045)$ & $(0.034)$ & $(0.047)$ & $(0.050)$ & $(0.048)$ & $(0.027)$ \\
Basic * Year 30 & 0.039 & 0.045 & 0.033 & 0.021 & 0.035 & 0.041 & 0.027 & 0.019 \\
Advanced * Year 1 & $(0.044)$ & $(0.049)$ & $(0.041)$ & $(0.033)$ & $(0.041)$ & $(0.043)$ & $(0.031)$ & $(0.033)$ \\
& $0.062^{* * *}$ & $0.081^{* * *}$ & $0.055^{* * *}$ & $0.050^{* * *}$ & $0.061^{* * *}$ & $0.073^{* * *}$ & $0.050^{* * *}$ & $0.043^{* * *}$ \\
Advanced * Year 5 & $(0.017)$ & $(0.023)$ & $(0.016)$ & $(0.015)$ & $(0.016)$ & $(0.018)$ & $(0.015)$ & $(0.012)$ \\
& $0.089^{* * *}$ & $0.101^{* * *}$ & $0.078^{* * *}$ & $0.066^{* * *}$ & $0.078^{* * *}$ & $0.097^{* * *}$ & $0.069^{* * *}$ & $0.057^{* * *}$ \\
Advanced * Year 10 & $(0.018)$ & $(0.027)$ & $(0.016)$ & $(0.013)$ & $(0.018)$ & $(0.019)$ & $(0.019)$ & $(0.015)$ \\
& $0.098^{* * *}$ & $0.155^{* * *}$ & $0.086^{* * *}$ & $0.079^{* * *}$ & $0.093^{* * *}$ & $0.143^{* * *}$ & $0.077^{* * *}$ & $0.066^{* * *}$ \\
Advanced * Year 20 & $(0.029)$ & $(0.033)$ & $(0.026)$ & $(0.02)$ & $(0.026)$ & $(0.029)$ & $(0.025)$ & $(0.020)$ \\
Advanced * Year 30 30 & $0.180^{* * *}$ & $0.267^{* * *}$ & $0.167^{* * *}$ & $0.154^{* * *}$ & $0.173^{* * *}$ & $0.253^{* * *}$ & $0.156^{* * *}$ & $0.142^{* * *}$ \\
& $(0.030)$ & $(0.044)$ & $(0.036)$ & $(0.027)$ & $(0.029)$ & $(0.029)$ & $(0.028)$ & $(0.018)$ \\
& $0.292^{* * *}$ & $0.309^{* * *}$ & $0.283^{* * *}$ & $0.272^{* * *}$ & $0.281^{* * *}$ & $0.289^{* * *}$ & $0.271^{* * *}$ & $0.261^{* * *}$ \\
Specification & $(0.038)$ & $(0.041)$ & $(0.031)$ & $(0.026)$ & $(0.037)$ & $(0.031)$ & $(0.037)$ & $(0.034)$ \\
\hline \hline
\end{tabular}

Notes. Selected annual $\beta_{t}$ coefficients and $\gamma_{t}$ coefficients from Equation 1 (columns 1 and 5), using the minimum production estimates from Clark (1995) (columns 2 and 6), the maximum production estimates (columns 3 and 7), and the minimum production estimates for basic and advanced plants and the maximum production estimates for comparison plants (columns 4 and 8). Output is logged quantities (in million tons) of steel. TFPQ is logged total factor productivity quantity, computed as $\log T F P Q=\log T F P R-\tilde{p}$, where $\widetilde{p}$ is the revenue-share weighted average of the prices of plant products, and TFPR is calculated using Gandhi et al. (2020)'s method. Standard errors are clustered at the plant level. ${ }^{* * *} \mathrm{p}<0.01,{ }^{* *} \mathrm{p}<0.05,{ }^{*} \mathrm{p}<0.1$. 
Table B.2: List of Variables, With Their Definitions and Sources

\begin{tabular}{|c|c|c|}
\hline Variable & Definition & Level, Source and Years of Coverage \\
\hline Log Steel & Logged million tons of steel produced & Plant-year, Steel Association, 1949-2000 \\
\hline Log Coke/Iron/Pig Iron & Logged million tons of coke/ iron/ pig iron used as input & Plant-year, Steel Association, 1949-2000 \\
\hline Log TFPQ & Total Factor Productivity Quantity; for estimation, see Appendix C. & Plant-year, Steel Association, 1949-2000 \\
\hline Log Oxygen & Logged tons of steel produced with the basic oxygen process & Plant-year, Steel Association, 1949-2000 \\
\hline Log Continuous Casting & Logged tons of steel produced with the continuous casting method & Plant-year, Steel Association, 1985-2000 \\
\hline Log International Standard & Logged million tons of steel above international standard & Plant-year, Steel Association, 1985-2000 \\
\hline$\%$ Engineers & Share of engineers out of total employment & Plant-year, Steel Association, 1949-2000 \\
\hline$\%$ Technicians & Share of high-skilled technicians out of total employment & Plant-year, Steel Association, 1949-2000 \\
\hline \% Unskilled & Share of unskilled workers out of total employment & Plant-year, Steel Association, 1949-2000 \\
\hline Log Workers & Total number of workers & Plant-year, Steel Association, 1949-2000 \\
\hline Log Value Added & Difference between firm gross income and intermediate inputs & Firm-year, Second Industrial Survey, 1985; China Industrial Enterprises, 1998-2013 \\
\hline Log Fixed Assets & Logged value of land, buildings, and machines owned by the firm & Plant-year, Steel Association, 1949-2000 \\
\hline & & Firm-year, Second Industrial Survey, 1985; China Industrial Enterprises, 1998-2013 \\
\hline Log Capital Stock & Calculated from gross fixed assets using the Perpetual Inventory Method (PIM), & Plant-year, Steel Association, 1949-2000 \\
\hline & see table notes. & Firm-year, Second Industrial Survey, 1985; China Industrial Enterprises, 1998-2013 \\
\hline Log TFPR & Total Factor Productivity Revenue; for estimation see Appendix C. & Firm-year, Second Industrial Survey, 1985; China Industrial Enterprises, 1998-2013 \\
\hline Log Revenues & Operating revenues & Firm-year, Second Industrial Survey, 1985; China Industrial Enterprises, 1998-2013 \\
\hline Log Exports & Logged value of exports & Firm-year, China Industrial Enterprises, 1998-2013 \\
\hline Log Industrial Output & Logged value of industrial production & Province-year, Statistical Yearbook, 1949-2013 \\
\hline Log Industrial Employment & Logged number of workers in industrial sector & Province-year, Statistical Yearbook, 1949-2013 \\
\hline Log GDP Capita & Logged GDP per capita & Province-year, Statistical Yearbook, 1949--2013 \\
\hline Log Investment & Logged value of government investments & Province-year, Statistical Yearbook, 1949-2013 \\
\hline STEM Universities & Share of universities offering a STEM degree per county & County-year, China Education Yearbooks, 1998--2013 \\
\hline Technical School & Number of technical schools per inhabitant per county & County-year, China Education Yearbooks, 1998--2013 \\
\hline Log College Graduates & Logged number of college graduates over population & County-year, China Education Yearbooks, 1998--2013 \\
\hline Log High-Skilled Workers & Logged number of high-skilled workers over population & County-year, China Education Yearbooks, 1998--2013 \\
\hline
\end{tabular}

Notes. To obtain a measure of firm capital stock from the fixed gross assets (fga), we use the Perpetual Inventory Method (PIM). First, we compute investment $I$ as the difference between the deflated current and the lagged $f g a$, and use the PIM formula $P_{t+1} K_{t+1}=P_{t+1}(1-\delta) P_{t} K_{t}+P_{t+1} I_{t+1}$, where $K$ is the quantity of capital, $P$ is its price (set equal to one percent, the interest rate to be paid back to the Soviet Union for the loan granted to China for the technology transfer program), $I$ is investment, and $\delta$ is the depreciation rate (set equal to 3.5 percent, according to the average estimated life of machine of 20 years (Lardy, 1995). However, this procedure is valid only if the base-year capital stock (the first year in the data for a given firm) can be written as $P_{0} K_{0}$, which is not the case here because $f g a$ is reported at its historic cost. To estimate its value at replacement cost, we use the $R^{G}$ factor suggested by Balakrishnan et al. (2000), $R^{G}=\frac{\left[(1+g)^{\tau+1}-1\right](1+\pi)^{\tau}[(1+g)(1+\pi)-1]}{g\left\{[(1+g)(1+\pi)]^{\tau+1}-1\right\}}$, where $\tau$ is the average life of machines (assumed to be 20 years, according to Lardy, 1995), $\pi$ is the average capital price $\frac{P_{t}}{P_{t-1}}$ equal to one percent, and $g$ is the (assumed constant) real investment growth rate $\frac{I_{t}}{I_{t-1}}$ from 1949 to 1978 (equal to 1.07821 , as from Statistics China). We multiply fga in the base year 1949 by $R^{G}$ to convert capital to replacement costs at current prices, which we then deflate using the price index for machinery and machine tools to express it in real terms. Finally, we apply the PIM formula. 


\section{Estimation of TFPQ and TFPR}

We assume a Cobb-Douglas production function

$$
Y_{i t}=A_{i t} K_{i t}^{\beta_{k}} L_{i t}^{\beta_{l}} M_{i t}^{\beta_{m}}
$$

where $Y_{i t}$ is the output of plant $i$ in year $t, K_{i t}$ is capital stock, $L_{i t}$ is total employment, $M_{i t}$ is materials, and $A_{i t}$ is the Hicksian-neutral productivity. These variables are defined in Table B.2. Taking natural logs, equation C.1 results in the linear production function

$$
y_{i t}=\beta_{0}+\beta_{k} k_{i t}+\beta_{l} l_{i t}+\beta_{m} m_{i t}+a_{i t}
$$

where lowercase letters refer to natural logarithms and $\beta_{0}$ measures the mean efficiency level across plants and over time.

We estimate equation C.2 using the methodology proposed by Gandhi et al. (2020) (GNR), who developed a nonparametric identification and estimation of gross-output production functions that employ a "proxy variable" in a similar vein as prior work by Olley and Pakes (1996) (OP) and Levinsohn and Petrin (2003) (LP).

For plants in the steel industry, we estimate total factor productivity quantity (TFPQ), which represents the true physical productivity (Foster et al., 2008), as we observe the physical quantities of output produced and of materials used (coke and iron), via the formula $\log$ TFPQ $=\log$ TFPR- $\log \widetilde{p}$, where $\widetilde{p}$ is the value added share weighted average of the prices of plant products, and TFPR (total factor productivity revenue) is calculated using the GNR method. For plants in all the industries, we estimate TFPR, where output is proxied by firm revenues, with the GNR method. All the nominal variables are deflated using the year-industry-specific deflator provided by Statistics China, with 1980 as the base year. A potential problem with using the year-industry-specific deflators is that they cannot control for plant-specific price shocks (De Loecker and Warzynski, 2012). However, this is not an issue in our context: China was a planned economy, meaning that the output and input prices were set yearly by the government and were the same for all firms in the same industry. As a result, our estimates suffer no bias due to plant-specific variation in output or input prices.

Appendix Table C.1 reports the coefficients on labor, capital, and materials estimated with the GNR method. For robustness, we also report the labor, capital, and materials coefficients estimated with the OP and LP methodologies, OLS, and the factor shares (Solow's residuals). All the coefficients are remarkably similar to the OLS ones, indicating that the correlation between factor elasticities and productivity shocks is negligible and that firms, probably given their large size, were not very responsive to productivity shocks. 
Because the country had a planned economy until at least the $1980 \mathrm{~s}$, two potential concerns arise in estimating TFP of Chinese firms. First, the average Chinese firm had limited decision-making power on inputs and output markets. However, as Hirata (2018) and Ji (2019) noted, treated and comparison plants, given their large size, were given substantial freedom in terms of inputs, labor choices, and output production decisions. ${ }^{5}$ Because firms were price-takers - in the sense that they could not affect output and input market prices with their production decisions as prices were set yearly by the government - and managers were rewarded based on profits, we can assume that these firms were choosing inputs and quantities to maximize profits and apply the proposed TFP estimation methodology. Second, Chinese prices did not necessarily reflect a market equilibrium, so a potential "quality bias" may arise if treated plants had used the same quantity of better-quality inputs than comparison plants. We solve this issue, testing for the possibility of a quality bias, as follows. First, we aggregated output and inputs using their average annual prices as reported by the American Iron and Steel Institute, computing TFPR and TFPQ with these values. Second, following de Roux et al. (2020), who show that the transmission bias and the quality bias offset when the production function is estimated with naive OLS, we use TFPR and then TFPQ with the OLSestimated factor shares. The results are nearly identical to those that use our baseline TFP estimation (Table C.2), thus corroborating the similarities between the OLS and the GNR factor shares estimation.

\footnotetext{
${ }^{5}$ The situation was radically different in small firms and agricultural communities, where the government
} strictly controlled inputs and outputs. 
Table C.1: Estimation of the Production Function

\begin{tabular}{|c|c|c|c|c|c|c|c|c|c|c|c|c|}
\hline & \multicolumn{3}{|c|}{ I. Steel } & \multicolumn{3}{|c|}{ II. Electricity } & \multicolumn{3}{|c|}{ III.Machinery } & \multicolumn{3}{|c|}{ IV. Coal } \\
\hline & $\beta_{l}$ & $\beta_{k}$ & $\beta_{m}$ & $\beta_{l}$ & $\beta_{k}$ & $\beta_{m}$ & $\beta_{l}$ & $\beta_{k}$ & $\beta_{m}$ & $\beta_{l}$ & $\beta_{k}$ & $\beta_{m}$ \\
\hline GNR & $\begin{array}{c}0.25^{* * *} \\
(0.02)\end{array}$ & $\begin{array}{c}0.24^{* * *} \\
(0.03)\end{array}$ & $\begin{array}{c}0.52^{* * *} \\
(0.05)\end{array}$ & $\begin{array}{c}0.21^{* * *} \\
(0.01)\end{array}$ & $\begin{array}{c}0.26^{* * *} \\
(0.03)\end{array}$ & $\begin{array}{c}0.51^{* * *} \\
(0.06)\end{array}$ & $\begin{array}{c}0.22^{* * *} \\
(0.02)\end{array}$ & $\begin{array}{c}0.19^{* * *} \\
(0.01)\end{array}$ & $\begin{array}{c}0.60^{* * *} \\
(0.04)\end{array}$ & $\begin{array}{c}0.22^{* * *} \\
(0.03)\end{array}$ & $\begin{array}{c}0.28^{* * *} \\
(0.03)\end{array}$ & $\begin{array}{c}0.51^{* * * *} \\
(0.06)\end{array}$ \\
\hline LP & $\begin{array}{c}0.33^{* * *} \\
(0.04)\end{array}$ & $\begin{array}{c}0.22^{* * *} \\
(0.02)\end{array}$ & $\begin{array}{c}0.50^{* * *} \\
(0.03)\end{array}$ & $\begin{array}{c}0.21^{* * *} \\
(0.02)\end{array}$ & $\begin{array}{c}0.26^{* * *} \\
(0.01)\end{array}$ & $\begin{array}{c}0.52^{* * *} \\
(0.05)\end{array}$ & $\begin{array}{c}0.21^{* * *} \\
(0.01)\end{array}$ & $\begin{array}{c}0.18^{* * *} \\
(0.02)\end{array}$ & $\begin{array}{c}0.60^{* * *} \\
(0.03)\end{array}$ & $\begin{array}{c}0.22^{* * *} \\
(0.02)\end{array}$ & $\begin{array}{c}0.24^{* * *} \\
(0.01)\end{array}$ & $\begin{array}{c}0.51^{* * * *} \\
(0.04)\end{array}$ \\
\hline $\mathrm{OP}$ & $\begin{array}{c}0.31^{* * *} \\
(0.03)\end{array}$ & $\begin{array}{c}0.20^{* * *} \\
(0.01)\end{array}$ & $\begin{array}{c}0.50^{* * *} \\
(0.05)\end{array}$ & $\begin{array}{c}0.20^{* * * *} \\
(0.03)\end{array}$ & $\begin{array}{c}0.28^{* * *} \\
(0.04)\end{array}$ & $\begin{array}{c}0.53^{* * *} \\
(0.05)\end{array}$ & $\begin{array}{c}0.21^{* * *} \\
(0.02)\end{array}$ & $\begin{array}{c}0.19^{* * *} \\
(0.01)\end{array}$ & $\begin{array}{c}0.57^{* * *} \\
(0.04)\end{array}$ & $\begin{array}{c}0.22^{* * *} \\
(0.02)\end{array}$ & $\begin{array}{c}0.25^{* * *} \\
(0.02)\end{array}$ & $\begin{array}{c}0.50^{* * *} \\
(0.03)\end{array}$ \\
\hline OLS & $\begin{array}{c}0.21^{* * *} \\
(0.01)\end{array}$ & $\begin{array}{c}0.22^{* * *} \\
(0.02)\end{array}$ & $\begin{array}{c}0.52^{* * *} \\
(0.05)\end{array}$ & $\begin{array}{c}0.19^{* * *} \\
(0.03)\end{array}$ & $\begin{array}{c}0.30^{* * *} \\
(0.02)\end{array}$ & $\begin{array}{c}0.52^{* * *} \\
(0.06)\end{array}$ & $\begin{array}{c}0.22^{* * *} \\
(0.02)\end{array}$ & $\begin{array}{c}0.19^{* * *} \\
(0.01)\end{array}$ & $\begin{array}{c}0.59^{* * *} \\
(0.05)\end{array}$ & $\begin{array}{c}0.20^{* * *} \\
(0.02)\end{array}$ & $\begin{array}{c}0.25 * * * \\
(0.03)\end{array}$ & $\begin{array}{c}0.52^{* * *} \\
(0.06)\end{array}$ \\
\hline \multirow[t]{3}{*}{ Factor Shares } & 0.24 & 0.26 & 0.50 & 0.20 & 0.26 & 0.51 & 0.20 & 0.22 & 0.60 & 0.21 & 0.26 & 0.51 \\
\hline & \multicolumn{3}{|c|}{ V. Nonferrous Metals } & \multicolumn{3}{|c|}{ VI. Chemicals and Pharma } & \multicolumn{3}{|c|}{$\underline{\text { VII. Oil }}$} & \multicolumn{3}{|c|}{$\underline{\text { VIII. Light Industry }}$} \\
\hline & $\overline{\beta_{l}}$ & $\beta_{k}$ & $\beta_{m}$ & $\beta_{l}$ & $\beta_{k}$ & $\beta_{m}$ & $\beta_{l}$ & $\beta_{k}$ & $\beta_{m}$ & $\beta_{l}$ & $\beta_{k}$ & $\bar{\beta}_{m}$ \\
\hline GNR & $\begin{array}{c}0.31^{* * *} \\
(0.02)\end{array}$ & $\begin{array}{c}0.20^{* * *} \\
(0.04)\end{array}$ & $\begin{array}{c}0.52^{* * *} \\
(0.03)\end{array}$ & $\begin{array}{c}0.21^{* * *} \\
(0.01)\end{array}$ & $\begin{array}{c}0.19^{* * *} \\
(0.02)\end{array}$ & $\begin{array}{c}0.61^{* * *} \\
(0.04)\end{array}$ & $\begin{array}{c}0.21^{* * *} \\
(0.01)\end{array}$ & $\begin{array}{c}0.20^{* * *} \\
(0.02)\end{array}$ & $\begin{array}{c}0.63^{* * *} \\
(0.05)\end{array}$ & $\begin{array}{c}0.20^{* * * *} \\
(0.03)\end{array}$ & $\begin{array}{c}0.21^{* * * *} \\
(0.04)\end{array}$ & $\begin{array}{c}0.52^{* * *} \\
(0.05)\end{array}$ \\
\hline LP & $\begin{array}{c}0.32^{* * *} \\
(0.02)\end{array}$ & $\begin{array}{c}0.22^{* * *} \\
(0.01)\end{array}$ & $\begin{array}{c}0.50^{* * *} \\
(0.04)\end{array}$ & $\begin{array}{c}0.19^{* * *} \\
(0.02)\end{array}$ & $\begin{array}{c}0.20^{* * *} \\
(0.02)\end{array}$ & $\begin{array}{c}0.59^{* * *} \\
(0.04)\end{array}$ & $\begin{array}{c}0.20^{* * *} \\
(0.04)\end{array}$ & $\begin{array}{c}0.21^{* * *} \\
(0.02)\end{array}$ & $\begin{array}{c}0.59^{* * *} \\
(0.05)\end{array}$ & $\begin{array}{c}0.20^{* * *} \\
(0.02)\end{array}$ & $\begin{array}{c}0.20 * * * \\
(0.02)\end{array}$ & $\begin{array}{c}0.51^{* * *} \\
(0.05)\end{array}$ \\
\hline $\mathrm{OP}$ & $\begin{array}{c}0.32^{* * *} \\
(0.03)\end{array}$ & $\begin{array}{c}0.21^{* * *} \\
(0.02)\end{array}$ & $\begin{array}{c}0.51^{* * *} \\
(0.03)\end{array}$ & $\begin{array}{c}0.22^{* * *} \\
(0.03)\end{array}$ & $\begin{array}{c}0.20^{* * *} \\
(0.01)\end{array}$ & $\begin{array}{c}0.60^{* * *} \\
(0.06)\end{array}$ & $\begin{array}{c}0.21^{* * *} \\
(0.03)\end{array}$ & $\begin{array}{c}0.25^{* * *} \\
(0.02)\end{array}$ & $\begin{array}{c}0.62^{* * *} \\
(0.06)\end{array}$ & $\begin{array}{c}0.19^{* * *} \\
(0.03)\end{array}$ & $\begin{array}{c}0.17^{* * *} \\
(0.02)\end{array}$ & $\begin{array}{r}0.52^{* * *} \\
(0.04)\end{array}$ \\
\hline OLS & $\begin{array}{c}0.35 * * * \\
(0.02)\end{array}$ & $\begin{array}{c}0.20^{* * * *} \\
(0.01)\end{array}$ & $\begin{array}{c}0.50^{* * *} \\
(0.06)\end{array}$ & $\begin{array}{c}0.20^{* * * *} \\
(0.03)\end{array}$ & $\begin{array}{c}0.19^{* * *} \\
(0.02)\end{array}$ & $\begin{array}{c}0.61^{* * *} \\
(0.04)\end{array}$ & $\begin{array}{c}0.22^{* * *} \\
(0.04)\end{array}$ & $\begin{array}{c}0.21^{* * *} \\
(0.02)\end{array}$ & $\begin{array}{c}0.62^{* * *} \\
(0.04)\end{array}$ & $\begin{array}{c}0.20^{* * *} \\
(0.02)\end{array}$ & $\begin{array}{c}0.20^{* * * *} \\
(0.01)\end{array}$ & $\begin{array}{r}0.52^{* * *} \\
(0.06)\end{array}$ \\
\hline Factor Shares & 0.31 & 0.22 & 0.52 & 0.19 & 0.22 & 0.58 & 0.20 & 0.21 & 0.683 & 0.20 & 0.21 & 0.51 \\
\hline
\end{tabular}

Notes. Coefficients on labor $\left(\beta_{l}\right)$, capital $\left(\beta_{k}\right)$, and intermediate goods $\left(\beta_{m}\right)$ estimated with the methodology proposed by Gandhi et al. (2020) (GNR), Petrin et al. (2004) (LP), or Olley and Pakes (1996) (OP), OLS regressions, and factor shares by industry. ${ }^{* * *} \mathrm{p}<0.01,{ }^{* *} \mathrm{p}<0.05,{ }^{*} \mathrm{p}<0.1$. 
Table C.2: Alternative TFP Estimations

\begin{tabular}{|c|c|c|c|}
\hline & \multicolumn{3}{|c|}{ Log TFPQ } \\
\hline & $(1)$ & $(2)$ & $(3)$ \\
\hline Basic * Year 1 & $\begin{array}{c}0.001 \\
(0.017)\end{array}$ & $\begin{array}{c}0.001 \\
(0.016)\end{array}$ & $\begin{array}{c}0.001 \\
(0.015)\end{array}$ \\
\hline Basic * Year 5 & $\begin{array}{c}0.106^{* * *} \\
(0.018)\end{array}$ & $\begin{array}{c}0.109^{* * *} \\
(0.016)\end{array}$ & $\begin{array}{c}0.111^{* * *} \\
(0.014)\end{array}$ \\
\hline Basic * Year 10 & $\begin{array}{c}0.128^{* * *} \\
(0.023)\end{array}$ & $\begin{array}{c}0.130^{* * *} \\
(0.027)\end{array}$ & $\begin{array}{c}0.137^{* * *} \\
(0.022)\end{array}$ \\
\hline Basic * Year 20 & $\begin{array}{c}0.081^{*} \\
(0.047)\end{array}$ & $\begin{array}{l}0.082^{*} \\
(0.044)\end{array}$ & $\begin{array}{c}0.083^{*} \\
(0.046)\end{array}$ \\
\hline Basic * Year 30 & $\begin{array}{c}0.035 \\
(0.041)\end{array}$ & $\begin{array}{c}0.038 \\
(0.043)\end{array}$ & $\begin{array}{c}0.040 \\
(0.046)\end{array}$ \\
\hline Basic * Year 40 & $\begin{array}{c}0.001 \\
(0.043)\end{array}$ & $\begin{array}{c}0.002 \\
(0.040)\end{array}$ & $\begin{array}{c}0.001 \\
(0.039)\end{array}$ \\
\hline Advanced $*$ Year 1 & $\begin{array}{c}0.061^{* * *} \\
(0.016)\end{array}$ & $\begin{array}{c}0.064^{* * *} \\
(0.014)\end{array}$ & $\begin{array}{c}0.069^{* * *} \\
(0.012)\end{array}$ \\
\hline Advanced $*$ Year 5 & $\begin{array}{c}0.078^{* * *} \\
(0.018)\end{array}$ & $\begin{array}{c}0.081^{* * *} \\
(0.017)\end{array}$ & $\begin{array}{c}0.085^{* * *} \\
(0.015)\end{array}$ \\
\hline Advanced $*$ Year 10 & $\begin{array}{c}0.093^{* * *} \\
(0.026)\end{array}$ & $\begin{array}{c}0.095^{* * *} \\
(0.025)\end{array}$ & $\begin{array}{c}0.099^{* * *} \\
(0.021)\end{array}$ \\
\hline Advanced $*$ Year 20 & $\begin{array}{c}0.173^{* * *} \\
(0.029)\end{array}$ & $\begin{array}{c}0.177^{* * *} \\
(0.032)\end{array}$ & $\begin{array}{c}0.179^{* * *} \\
(0.033)\end{array}$ \\
\hline Advanced $*$ Year 30 & $\begin{array}{c}0.281^{* * *} \\
(0.037)\end{array}$ & $\begin{array}{c}0.286^{* * *} \\
(0.041)\end{array}$ & $\begin{array}{c}0.293^{* * *} \\
(0.043)\end{array}$ \\
\hline Advanced * Year 40 & $\begin{array}{c}0.391^{* * *} \\
(0.035)\end{array}$ & $\begin{array}{c}0.398^{* * *} \\
(0.039)\end{array}$ & $\begin{array}{c}0.401^{* * *} \\
(0.036)\end{array}$ \\
\hline Main Specification & Yes & No & No \\
\hline Using US Prices & No & Yes & No \\
\hline Using OLS & No & No & Yes \\
\hline Observations & 12,160 & 12,160 & 12,160 \\
\hline
\end{tabular}

Notes. Selected annual $\beta_{t}$ coefficients and $\gamma_{t}$ coefficients from Equation 1 computing total factor productivity as $\log T F P Q=\log T F P R-\tilde{p}$, where $\widetilde{p}$ is the revenue-share weighted average of the prices of plant products, and TFPR is calculated using Gandhi et al. (2020)'s method (column 1), TFPR is calculated using American Iron and Steel Institute price (column 2), and using OLS to offset transmission and quality bias as explained in de Roux et al. (2020) (column 3). Standard errors are clustered at the plant level. ${ }^{* * *} \mathrm{p}<0.01,{ }^{* *} \mathrm{p}<0.05,{ }^{*} \mathrm{p}<0.1$. 


\section{References}

Abadie, Alberto, Susan Athey, Guido Imbens, and Jeffrey M. Wooldridge, "When Should You Adjust Standard Errors for Clustering?," NBER Working Paper, 2017, 24003.

Ackerberg, Daniel A., Kevin Caves, and Garth Frazer, "Structural Identification of Production Functions," 2006.

_ , _ , and _ , "Structural Identification of Production Functions," Econometrica, 2015, $8 \overline{3}(6), 241 \overline{1}-51$.

Andrews, Donald W. K. and Vadim Marmer, "Exactly Distribution-free Inference in Instrumental Variables Regression with Possibly Weak Instruments," Journal of Econometrics, 2008, 142 (1), 183-200.

Balakrishnan, Pulapre K., K. Pushpangadan, and M. Suresh Babu, "Trade Liberalisation and Productivity Growth in Manufacturing: Evidence from Firm-Level Panel Data," Economic and Political Weekly, 2000, 35 (41), 3679-3682.

Bertrand, Marianne, Ester Duflo, and Sendhil Mullainathan, "How Much Should We Trust Differences-in-Differences Estimates?," Quarterly Journal of Economics, 2004, 119 (1), 249-75.

Bloom, Nicholas, Benn Eifert, Aprajit Mahajan, David Mckenzie, and John Roberts, "Does Management Matter? Evidence from India," Quarterly Journal of Economics, 2013, 128 (1), 1-51.

Blundell, Richard and Stephen Bond, "GMM Estimation with persistent panel data: an application to production functions," Econometric Reviews, 2000, 19 (3), 321-340.

Bond, Stephen and Mans Soderbom, "Adjustment Costs and the Identification of Cobb Douglas Production Functions," 2005.

Cameron, A. Colin, Jonah B. Gelbach, and Douglas L. Miller, "BootstrapBased Improvements for Inference with Clustered Errors," Review of Economics and Statistics, 2008, 90 (3), 414-27.

Canay, Ivan, Andres Santos, and Azeem Shaikh, "The Wild Bootstrap with a Small Number of Large Clusters," Review of Economics and Statistics, 2021, p. forthcoming.

Clark, Gardner, Development of China's Steel Industry and Soviet Technical Aid, Cornerll University, 1973. "The Chinese Steel Industry, 1949-1993," 1995.

De Loecker, Jan and Frederic Warzynski, "Markups and firm-level export status," American Economic Review, 2012, 102 (6), 2437-2471.

_, Pinelopi K. Goldberg, Amit K. Khandelwal, and Nina Pavcnik, "Price, Markups and Trade Reform," Econometrica, 2016, 84 (2), 445-510.

de Roux, Nicolas, Marcela Eslava, Santiago Franco, and Eric Verhoogen, "Estimating Production Functions in Differentiated-Product Industries with Quantity Information and External Instruments," NBER Working Paper, 2020, 28323.

Dong, Zhifan and Jiang Wu, The Industry Cornerstone of People's Republic of China, 156 projects in 1950-2000, Guangdong Economy Press, 2004.

Foster, Lucia, John Haltiwanger, and Chad Syverson, "Reallocation, Firm Turnover, and Efficiency: Selection on Productivity or Profitability?," American Economic Review, 2008, 98 (1), 394-425.

Galuščák, Kamil and Líza Lubomír, "The Impact of Capital Measurement Error Correction on Firm-Level Production Function Estimation," 2011.

Gandhi, Amit, Salvador Navarro, and David A. Rivers, "On the Identification of Gross Output Production Functions," Journal of Political Economy, 2020, 128 (8), 2973-3016.

Greevy, Robert, Jeffrey H. Silber, Avital Cnaan, and Paul R. Rosenbaum, "Randomization Inference with Imperfect Compliance in the CE-Inhibitor," Journal of the American Statistical Association, 2004, 99 (465), 7-15.

Hirata, Koji, "Steel Metropolis: Industrial Manchuria and the Making of Chinese Socialism, 1916-1964." PhD dissertation 2018.

Ibragimov, Rustam and Ulrich Muller, "t-statistic Based Correlation and Heterogeneity Robust Inference," Journal of Business and Economic Statistics, 2010, 28 (4), 453-68.

ISTAT, "Nota Metodologica sulle Misure di Produttività," Technical Report 2012.

Ji, Siyou, The Memoirs of Workers at Ansteel, Metallurgical Industry Press, 2019. 
Klette, Tor Jakob and Zvi Griliches, "The Inconsistency of Common Scale Estimators when Output Prices Are Unobserved and Endogenous," Journal of Applied Econometrics, 1996, 11 (4), 343-61.

Lardy, Nicholas, "Emulating the Soviet Model, 1949-1957," in Roderick MacFarquhar and John K. Fairbank, eds., The Cambridge History of China. Volume 14. The People's Republic of China: the Emergence of Revolutionary China, 1949-1965., Cambridge: Cambridge University Press, 1995, p. 722.

Levinsohn, James and Amil Petrin, "Production Functions Estimating to Control for Using Inputs Unobservables," Review of Economic Studies, 2003, 70 (2), 317-341.

MacKinnon, James and Matthew Webb, "Thw Wild Bootstrap for (Few) Treated Clusters," Journal of Econometrics, 2018, 2 (21), 114-35.

Mundlak, Yair, "Empirical Production Function Free of Management Bias," Agricultural Applied Economics Association, 1961, 43 (1), 44-56.

Olley, G. Steven and Ariel Pakes, "The Dynamics of Productivity in the Telecommunications Equipment Industry," Econometrica, 1996, 64 (6), 1263-1297.

Petrin, Amil, Brian P. Poi, and James Levinsohn, "Production Function Estimation in Stata Using Input to Estimate the Unobservables," Stata Journal, 2004, 4 (2), $113-123$.

Wooldridge, Jeffrey M., "On estimating firm-level production functions using proxy variables to control for unobservables," Economics Letters, 2009, 104 (3), 112-114.

Zamagni, Vera, Come Perdere la Guerra e Vincere la Pace. L'Economia Italiana tra Guerra e Dopoguerra: 1938-194\%, Bologna: Il Mulino, 1997.

Zhang, Baichun, Fang Yao, Jiuchun Zhang, and Long Jiang, The Technology Transfer from Soviet Union to China, 1949-1966, Shandong Education Press, 2003. 